\title{
Women Redefining Justice: The International Tribunal on Crimes Against Women of Burma
}

\author{
By \\ Shannon Sommerauer \\ B.A., University of Toronto, 2005 \\ B.S.W., Carleton University, 2009
}

A thesis submitted to the Faculty of Graduate Studies and Research in partial fulfillment of the requirements for the degree of

Master

in

Social Work

Carleton University

Ottawa, Ontario

(C) 2011, Shannon Sommerauer 


$\begin{array}{ll}\begin{array}{l}\text { Library and Archives } \\ \text { Canada }\end{array} & \begin{array}{l}\text { Bibliothèque et } \\ \text { Archives Canada }\end{array} \\ \begin{array}{l}\text { Published Heritage } \\ \text { Branch }\end{array} & \begin{array}{l}\text { Direction du } \\ \text { Patrimoine de l'édition }\end{array} \\ \begin{array}{l}\text { 395 Wellington Street } \\ \text { Ottawa ON K1A 0N4 } \\ \text { Canada }\end{array} & \begin{array}{l}\text { 395, rue Wellington } \\ \text { Ottawa ON K1A ON4 } \\ \text { Canada }\end{array}\end{array}$

Your file Votre référence

ISBN: 978-0-494-79598-9

Our file Notre référence

ISBN: 978-0-494-79598-9

NOTICE:

The author has granted a nonexclusive license allowing Library and Archives Canada to reproduce, publish, archive, preserve, conserve, communicate to the public by telecommunication or on the Internet, loan, distribute and sell theses worldwide, for commercial or noncommercial purposes, in microform, paper, electronic and/or any other formats.

The author retains copyright ownership and moral rights in this thesis. Neither the thesis nor substantial extracts from it may be printed or otherwise reproduced without the author's permission.

\begin{abstract}
AVIS:
L'auteur a accordé une licence non exclusive permettant à la Bibliothèque et Archives Canada de reproduire, publier, archiver, sauvegarder, conserver, transmettre au public par télécommunication ou par l'Internet, prêter, distribuer et vendre des thèses partout dans le monde, à des fins commerciales ou autres, sur support microforme, papier, électronique et/ou autres formats.
\end{abstract}

L'auteur conserve la propriété du droit d'auteur et des droits moraux qui protège cette thèse. $\mathrm{Ni}$ la thèse ni des extraits substantiels de celle-ci ne doivent être imprimés ou autrement reproduits sans son autorisation.
In compliance with the Canadian Privacy Act some supporting forms may have been removed from this thesis.

While these forms may be included in the document page count, their removal does not represent any loss of content from the thesis.
Conformément à la loi canadienne sur la protection de la vie privée, quelques formulaires secondaires ont été enlevés de cette thèse.

Bien que ces formulaires aient inclus dans la pagination, il n'y aura aucun contenu manquant. 


\begin{abstract}
It is widely recognized that women suffer in different and disproportionate ways in times of war and armed conflict. Yet, international human rights law has been criticized for privileging the realities of men's lives while ignoring or marginalizing those of women. This thesis project is comprised of an exploratory single-case study examining one such women's tribunal, the International Tribunal on Crimes Against Women of Burma, convened in early March 2010 in New York City. This paper explores the testimonies of the New York Tribunal, and identifies themes which emerged from these testimonies. It outlines the political and civil society outputs and outcomes of the Tribunal, especially highlighting the role of internet-based material and social media. Finally, this thesis explores the potential role and contributions of popular tribunals in women's justice and advocacy efforts.
\end{abstract}


For my sisters - Lindsay, Lauren, Abbey, Elora, Jillian and BrienneThat we may one day live in a world where all women live free from violence and fear;

And for the women of Burma - who continue to inspire with their resiliency, strength and determination to create a better future for their people. 


\section{Acknowledgements}

As with any project of this size, it would have been impossible to undertake alone. There are many people I need to thank - who offered their support, encouragement, and ideas as I went on this year-long journey following the International Tribunal on Crimes Against Women of Burma.

First, I want to thank my supervisor at Carleton University, Steve Hick, for his support of this project and for providing me with tools for maintaining personal balance, which have been invaluable during this thesis process. I also wish to thank my second reader, Karen Schwartz, as well as Adje van de Sande, who stepped in on short notice and helped me greatly in shaping this project. Also at Carleton, Augustine Park and Christiane Wilke challenged me in new ways and opened my thinking about justice after atrocity.

I must offer sincere thanks to my family and friends, who have supported and encouraged me throughout this year. Kim and $\mathrm{Al}$ Gayed and Lindsay Sommerauer talked me down more than once, when I was feeling overwhelmed. Andrew Gayed and Abbey Sommerauer inspired me with their enthusiasm and questions. I especially want to thank my father, John Sommerauer, who joined me in New York City, and gave me someone with whom I could relax and have fun after spending the day listening to the harrowing Tribunal testimony.

This project would not have been possible without the support of the wonderful staff at the Nobel Women's Initiative, who have shaped me considerably and have taught me more than I can say. A special thank you must be offered to Julaine Eberhard, Nadia Kalinchuk, Kim Mackenzie, and Erin Simpson, who convinced me that I was capable of taking on a thesis in the first place.

Of course, the real heroines and inspiration of this project are the women of Burma. Without their courageous resistance and resiliency, this thesis would absolutely not have been possible. They continue to inspire and motivate me every day.

Finally, a special thank you to Randy Douma, who provided me with constant love, encouragement and support, gave me a quiet place to decompress, and who reminds me that ordinary people can do extraordinary things. 


\section{Contents}

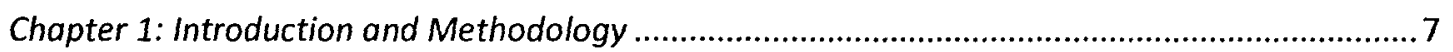

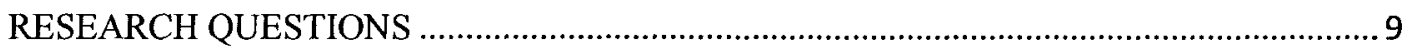

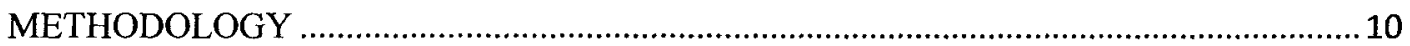

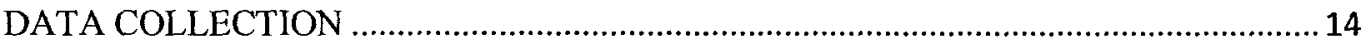

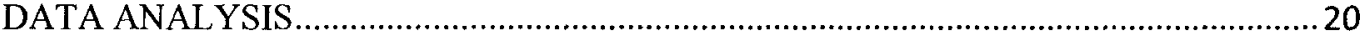

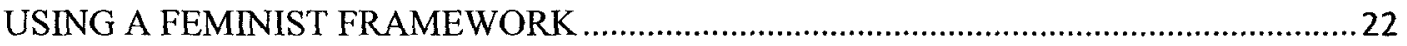

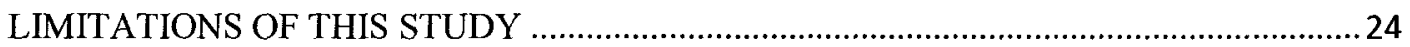

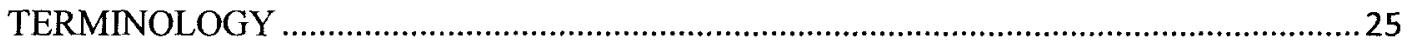

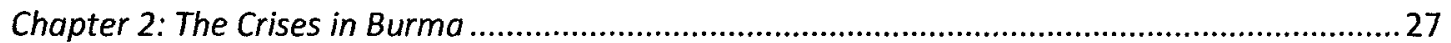

BRIEF HISTORY OF MILITARY RULE \& PRO-DEMOCRACY PROTESTS.....................28

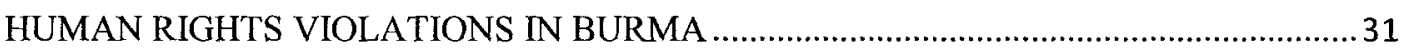

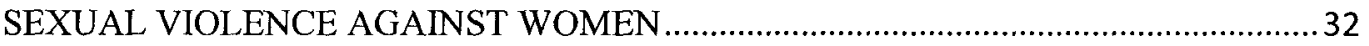

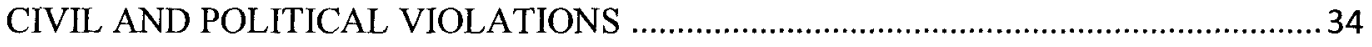

SOCIAL, CULTURAL AND ECONOMIC VIOLATIONS ................................................

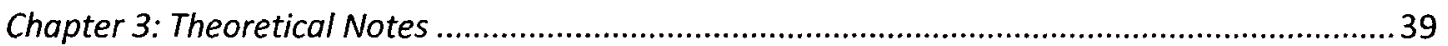

THE NATURE OF WARTIME VIOLENCE AGAINST WOMEN ...................................... 40

FACTORS CONTRIBUTING TO WAR TIME VIOLENCE - UNDERSTANDING

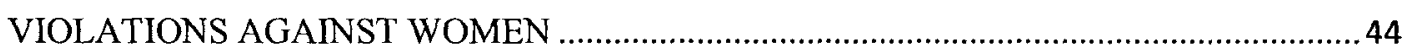

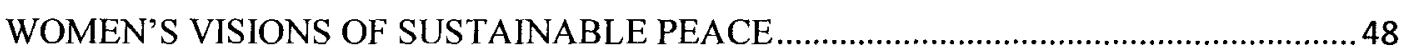

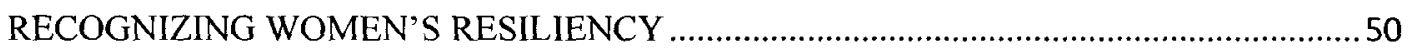

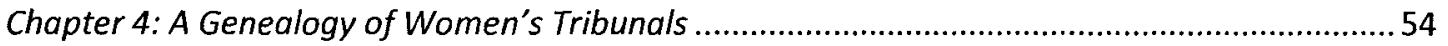

THE GLOBAL TRIBUNAL ON VIOLATIONS OF WOMEN'S HUMAN RIGHTS, VIENNA. .56

THE WOMEN'S INTERNATIONAL TRIBUNAL ON JAPANESE MILITARY SEXUAL

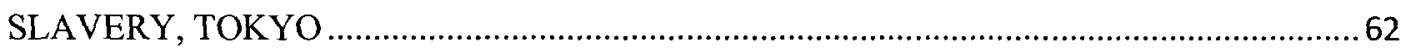

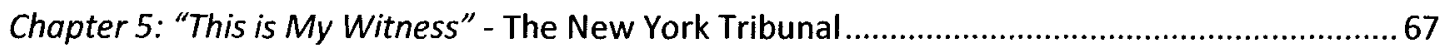

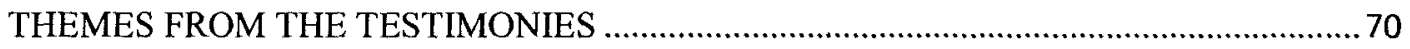

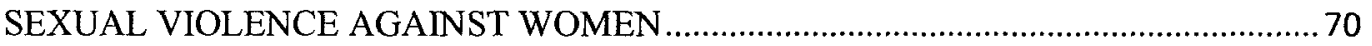

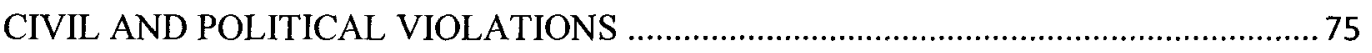

SOCIAL, ECONOMIC AND CULTURAL VIOLATIONS ….............................................

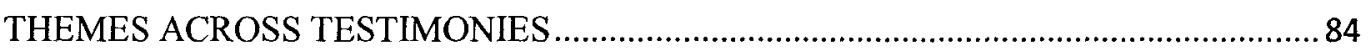


THE JUDGES' FINDINGS AND RECOMMENDATIONS ....................................................

Chapter 6: Amplifying Women's Voices - The Outcomes of the New York Tribunal ...................... 96

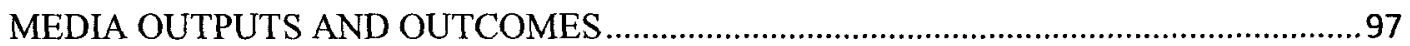

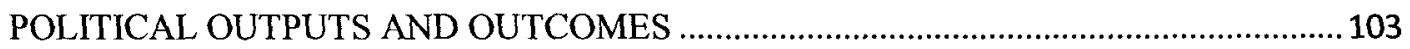

MEETING WITH UN SECRETARY-GENERAL BAN KI-MOON ................................ 104

MEETINGS WITH UN SECURITY COUNCIL MEMBERS …........................................ 105

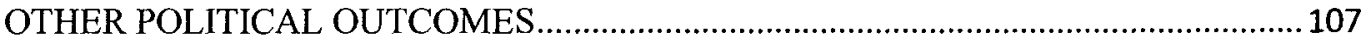

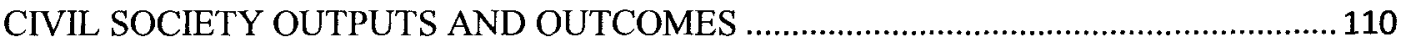

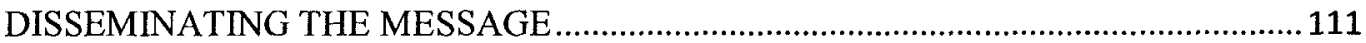

CHOOSING MOMENTS: THE NEW YORK TRIBUNAL AS AN ADVOCACY TOOL

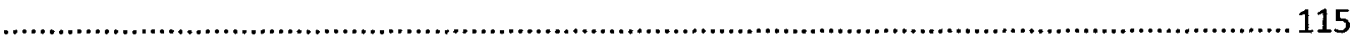

SPREADING THE MESSAGE: SOCIAL MEDIA ….................................................... 121

Conclusion: Looking to the Future - Women Redefining Justice............................................... 130

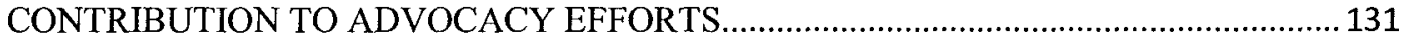

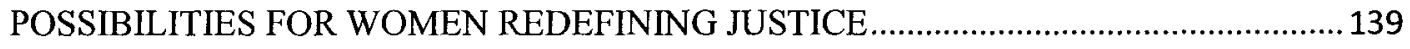

RECOMMENDATIONS FOR FURTHER RESEARCH …............................................

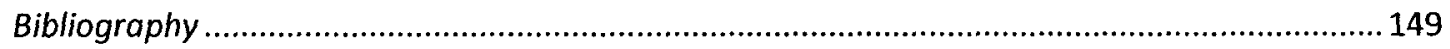

APPENDIX I: Online Representation of the International Tribunal on Crimes Against Women of

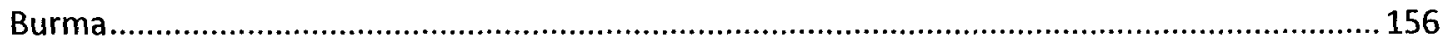

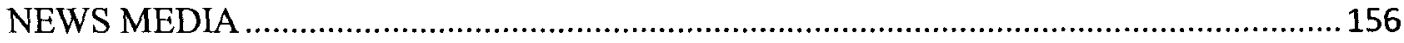

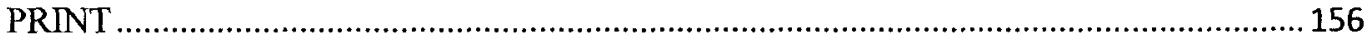

RADIO

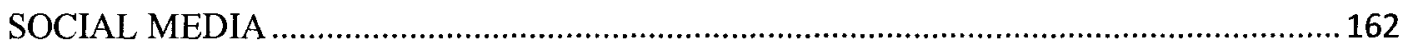

FACEBOOK

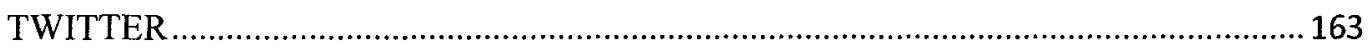

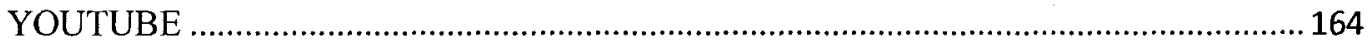

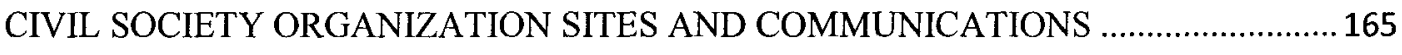

APPENDIX II: Advocacy Letter to Ban Ki-moon, Sent with the New York Tribunal Report.......... 175

APPENDIX II: Turning Information into Action - What You Can Do for Burma ............................177

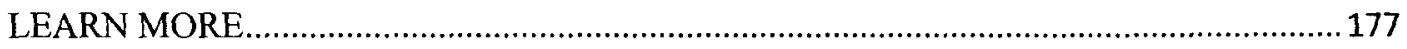

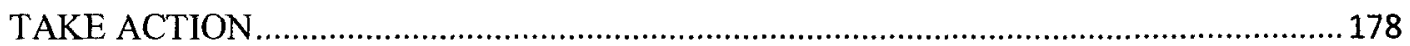


"I think this is the case in the great majority of authoritarian states: On the surface, because of repression, everything seems frozen, but when the sun comes out and the ice melts, you find that there was a lot of life underneath all along."

- Aung San Suu Kyi 
Chapter 1: Introduction and Methodology 


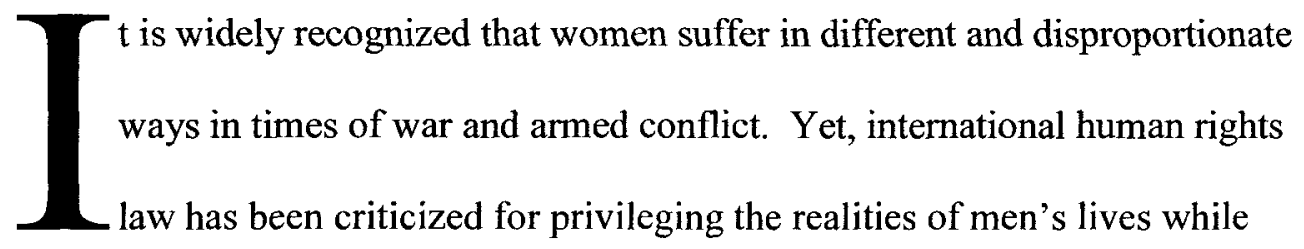
ignoring or marginalizing those of women (Edwards, 2006). Documents such as the United Nations Security Council resolutions on "Women, Peace and Security" represent an attempt to incorporate these experiences into international law. People's tribunals, particularly women's tribunals, have provided another attempt to break down the walls of silence surrounding women's experiences of armed conflict.

This thesis project is comprised of an exploratory single-case study examining one such women's tribunal, the International Tribunal on Crimes Against Women of Burma. The International Tribunal on Crimes Against Women of Burma (the New York Tribunal) convened in early March 2010 in New York City. It was scheduled to coincide with the annual meeting of the UN Commission on the Status of Women (CSW). Organizers aimed to take advantage of a situation in which UN delegates were focused on the conditions of women worldwide, in order to draw particular attention to crimes against the women of Burma. The New York Tribunal was also intended as a strategic advocacy moment to draw attention to human rights violations ahead of the national elections scheduled for fall 2010 in Burma.

The New York Tribunal was organized internationally by two NGOs - the Nobel Women's Initiative and the Women's League of Burma. The Nobel Women's Initiative (NWI) was established by six women Nobel Peace Laureates to work for peace, justice and equality by spotlighting and promoting the work of women's organizations. Burma 
has been one of NWI's key advocacy areas since the organization's inception. The Women's League of Burma (WLB) is an umbrella organization of 12 women's ethnic organizations from across Burma. The WLB is based in northern Thailand, near the Thailand-Burma border.

The New York Tribunal was a day-long event, comprised of 12 testimonies by women of Burma. Similar to past women's tribunals, testimonies were organized into categories in order to address a wide range of human rights violations. These categories served to underscore the systemic nature of human rights abuses in Burma. A panel of judges, including Nobel Laureates and international law experts, made closing remarks and recommendations linking the testimonies to international human rights and legal standards, and called on the Burmese regime, the international community and international civil society to take specific actions for justice in Burma.

\section{RESEARCH QUESTIONS}

In examining the New York Tribunal, I am most concerned with its outcomes in civil society. Indeed, given that people's tribunals are not legally enforceable, their effectiveness may be measured most accurately by not only accounting for their outcomes in the international (governmental) community, but also their outcomes in international civil society. As such, this thesis addresses the following research questions and sub-questions:

- First, how did the New York Tribunal contribute to advocacy efforts for justice in Burma? 
- What were the political outcomes of the New York Tribunal?

- What were the civil society outcomes of the New York Tribunal? How did non-governmental organizations use the Tribunal to advance their own advocacy efforts?

- How did the New York Tribunal contribute to women's advocacy efforts in particular?

- Second, based on my analysis of the single case of the New York Tribunal, what potential role can we see for popular tribunals in future advocacy efforts?

- How might popular tribunals contribute to the pursuit of justice for women in particular?

o How might civil society, including social work, contribute to these efforts?

-What are the lessons learned for future efforts?

\section{METHODOLOGY}

In this thesis, I examine the International Tribunal on Crimes Against Women of Burma as an exploratory single-case study. In case studies, "multiple variables are investigated and generalization is fundamentally analytic, inferential and impressionistic" (Brandell \& Varkas, 2010, p. 377). Yin provides the following two-part definition of case studies: 
A case study is an empirical inquiry that

- Investigates a contemporary phenomenon in depth and within its reallife context, especially when

- The boundaries between phenomenon and context are not clearly evident...

The case study inquiry

- Copes with the technically distinctive situation in which there will be many more variables of interest than data points, and as one result

- Relies on multiple sources of evidence with data needing to converge in a triangulating fashion, and as another result

- Benefits from the prior development of theoretical propositions to guide data collection and analysis (Yin, 2009, p. 18).

The case study at hand explores the phenomenon and context of the New York Tribunal, and frames this exploration within a broader feminist theoretical framework, to be discussed further in Chapter 3. Yegidis, Weinbach and Morrison-Rodriguez argue that exploratory research is appropriate when the understanding of a problem or phenomenon is quite limited, and that it is therefore conducted in order to lay the groundwork for future knowledge-building (1999). I have chosen an exploratory model because women's tribunals are a relatively new phenomenon, and so the literature on these interventions is still in its infancy. Furthermore, many of the advocacy tools used to bring the New York Tribunal to the public, such as online social media, are also in their early stages, and have therefore not been the subject of significant research.

Yin argues that while case studies cannot be generalized to populations, they are generalizable to theoretical propositions, and that their goal can be to expand and generalize theories (2009). Indeed, Brandell and Varkas write that case studies "allow for the integration of theoretical perspective, intervention and outcome" (2010, p. 379). Rubin and Babbie also describe the focus of case studies as the connection between the findings of a particular case study to a broader theory. They argue that a case study 
focusing on a significant event and its impact can inform future related policy considerations (Rubin \& Babbie, 2005). This is indeed the aim of this thesis project. Rather than generalizing the findings of this research to a broader population, I seek to contribute to feminist civil society advocacy considerations. In these ways, an exploratory single-case study design is well-suited to this thesis project.

Yin suggests the use of a single-case, embedded study design when both an event and its context will be studied. This design allows for more than one unit of analysis to be included in the study design. Indeed, the same study may include a main unit, sub-units and their broader context (2009). For the purposes of this thesis, the New York Tribunal serves as the main unit of analysis, with its political and civil society outcomes (subunits), as well as its broader context also included in the scope of the study.

In order to undertake this project, I have collected data indicating the political and civil society outcomes of the New York Tribunal from January 1 to July 1, 2010. I felt it necessary to limit the time period covered by the case study, not only to clearly define the case, but also in recognition of the time restraints of this thesis. However, I believe that the political and civil society outcomes most directly related to the New York Tribunal will be found within this time frame. The only clear exception to this is the release of a short documentary on the Tribunal, which took place in New York in September 2010.

Yin emphasizes the importance of maintaining a "chain of evidence" within one's case study, in order to increase the reliability of the study. A clear chain of evidence means that the reader should easily be able to follow the case study report from the research 
questions and methodology to the data and finally to the conclusions (Yin, 2009).

Brandell and Varkas offer the following model format for case study research:

1. Identification of the issue being studied.

2. Review of relevant prior literature.

3. Identification of data collection methods and sources.

4. Description of findings from collected and analyzed data.

5. Development of conclusions and implications for further study (2010, p. 381).

The structure of this thesis project, outlined below, closely mirrors this suggested format:

1. Identification of the issue being studied.

- Found in this first, introductory chapter.

2. Identification of data collection methods and sources.

- To be discussed below in this first, introductory chapter.

3. Review of relevant prior literature.

- In order to ensure that the reader can fully immerse themselves in the discussion of the International Tribunal for Crimes Against Women of Burma, I provide some background information on the crises in Burma (Chapter 2), on the feminist framework to be used in my analysis (Chapter 3 ), and on previous women's tribunals (Chapter 4).

4. Description of findings from collected and analyzed data.

- Chapter 5 discusses the International Tribunal on Crimes Against Women of Burma. This chapter provides an overview of the Tribunal process, and highlights the themes which emerged, both within and across the three sessions of testimony - on sexual violence against women, civil and political violations and social, economic and cultural violations. The fifth chapter also outlines the judges' statements and recommendations from their findings at the New York Tribunal.

- Chapter 6 examines the outcomes of the New York Tribunal. It discusses the press conference and meetings with United Nations personnel, 
including UN Secretary-General Ban Ki-moon, which took place the day following the Tribunal. It also explores the broader outcomes of the Tribunal, including both its political and civil society outcomes, as described above.

5. Development of conclusions and implications for further study.

- The Conclusion looks toward the future, and assesses the potential role of popular tribunals in future advocacy efforts. It addresses what the case of the International Tribunal on Crimes Against Women of Burma can teach us about the role civil society can play in women's advocacy. Finally, I conclude by identifying lessons for the future and recommend potential areas for further study.

It is my belief that this structure allows me to present this complex project in a manner that is coherent, and that provides a clear chain of evidence. The diagram on the following page illustrates the chain this study will take. We will return to this diagram in Chapter 6 in order to clearly demonstrate the chain of evidence found in this thesis project.

\section{DATA COLLECTION}

Yin advocates applying three principles of data collection in case study research. First, he promotes using multiple, rather than single, sources of evidence. Second, he suggests creating a case study data base, or clear documentation of data collection and sources. Third, he advocates maintaining a clear chain of evidence, as discussed above $(2009$, p. 101). These strategies aim to increase the construct validity and reliability of the case study by triangulating data and making it possible for others to replicate the study. I employ each of these strategies in this thesis project. 


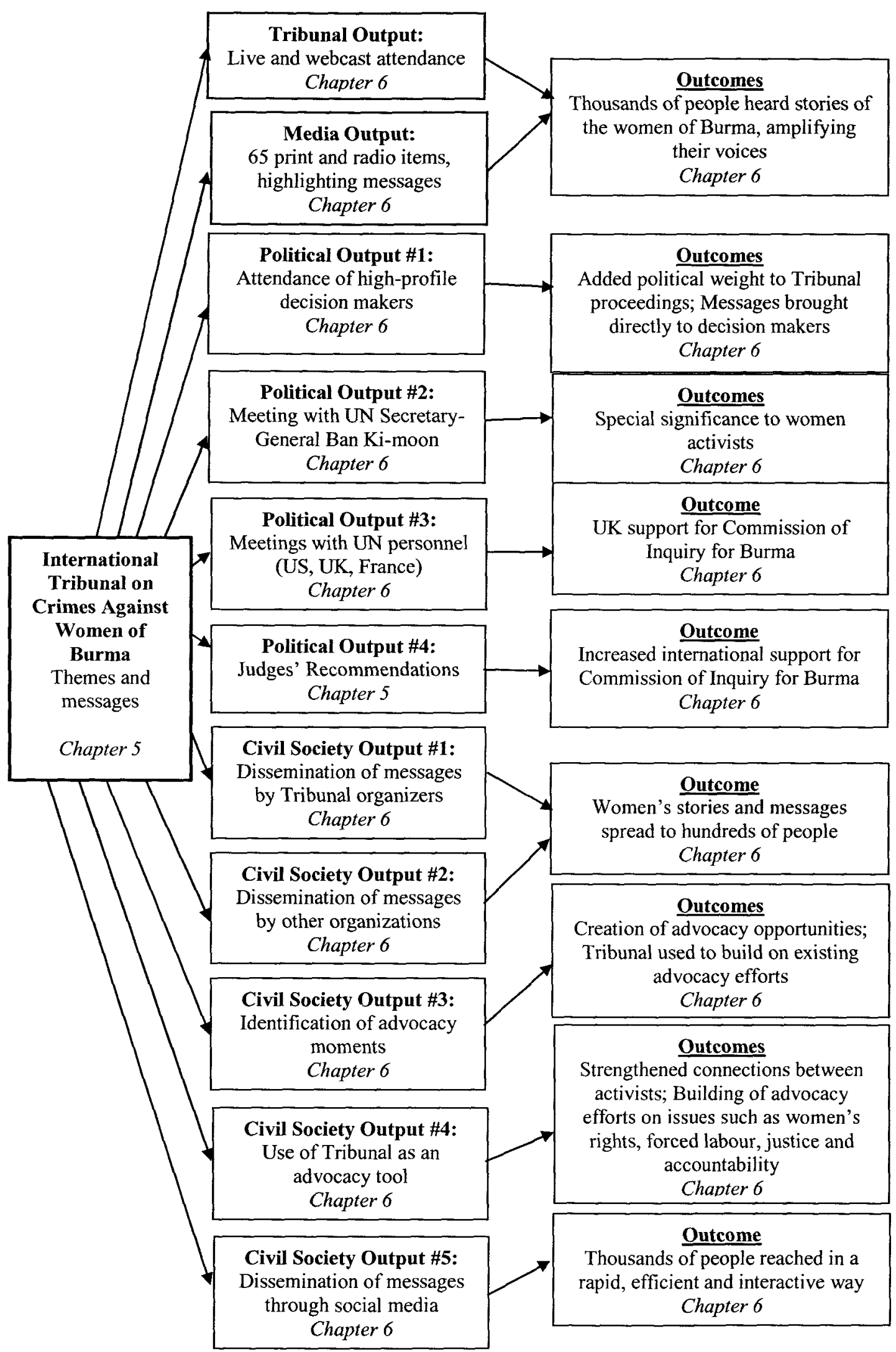


Case studies can rely on a variety of data sources (Rubin \& Babbie, 2005; Yin, 2009). In fact, Yin argues that the use of multiple data sources in a case study can be advantageous in that it offers a way of triangulating evidence in order to draw more valid conclusions. He writes that case studies using multiple sources of evidence have been found to be rated more highly in terms of overall quality when compared to studies using only a single source of evidence (2009). For the purposes of this study, I employ what Madill and Gough describe as a "naturally-occurring" qualitative method of data collection, meaning that I bring together a diverse collection of texts which have been generated in everyday life (2008). In other words, my data sources have the advantage of not being created for this study. Indeed, the research process for this thesis involved a significant amount of primary and secondary document research. These documents include books and journal articles, governmental documents, reports from non-governmental organizations, news reports, and a variety of internet-based material. I have provided a detailed list of the sources used, (both in my bibliography and in Appendix I), which constitutes my case study database. In this way, I aim to make replication of my study as easy as possible, and therefore strengthen the reliability of this thesis project.

Yin's single-case, embedded study design recognizes that different units and sub-units of analysis within the same single-case study may require different data sources (2009). Broadly speaking, books and journal articles comprise the major sources of data for developing the theoretical context of this thesis. These sources were chosen in order to provide a comprehensive overview of the relevant literature. In Chapter 3, I develop a framework to understand violations against women through a feminist lens and with a 
recognition of women's resiliency. Books and journal articles also provided some background information on previous women's tribunals.

One particularly important source for my data collection has been the testimonies and judges' statements from the International Tribunal on Crimes Against Women of Burma. I attended the Tribunal in New York in early March 2010. The Tribunal was open to the public and was broadcast live over the internet, with the result that the testimony is still widely available. In addition to observing the Tribunal, I also tape recorded the entire event, as well as the judges' press conference the following day. These recordings have been entirely transcribed in order to provide research material for this thesis project. As the Tribunal was open to the public and the testimonies continue to be publically available following the close of the Tribunal, the use of this material will provide no additional risk to Tribunal testifiers. It should be noted that some of the women's names were changed, both in the Tribunal testimony and in subsequent reports, in order to protect their safety and that of their families. The real names of these women are unknown to this researcher; therefore, the altered names are the only names that are used in this thesis report.

In addition to the Tribunal transcript, governmental documents, reports from nongovernmental organizations, news reports, and internet-based material serve as the major sources of data pertaining to the ongoing crises in Burma and to the New York Tribunal and its outcomes. In terms of data relating to the situation in Burma, I have striven to select data sources from the most objective and credible sources. These include governmental sources such as the United Nations and its agencies, as well as respected 
non-governmental organizations such as Amnesty International and Human Rights Watch. I have also worked to ensure that Burmese women's voices are represented among these sources.

Data regarding the New York Tribunal and its outcomes comes from a wide variety of sources, including relevant governmental documents, non-governmental advocacy documents (to be discussed further below), news reports and internet-based material including websites, social media and online communications. The Burma advocacy network is fairly well connected internationally, so data sources effectively 'snowballed' on one another. My own knowledge of and experiences with this advocacy network allowed me to identify a number of the major organizations involved. From there, data sources snowballed outwards. For example, one organization may have sent a communication about the Tribunal through their email newsletter. This email communication may have linked back to a news item about the Tribunal on the organization's website, which further linked to various news articles or to another organization's website. Here again I have striven to ensure that Burmese voices are included prominently. Internet-based sources were chosen based on the following criteria:

1. Relevance to the New York Tribunal and its impact.

2. Published between January 1 and July 1, 2010.

3. Reflective of type and scope of available sources regarding the New York Tribunal. 
Rubin and Babbie suggest that popular media can be an important knowledge source, so long as it is accompanied by media literacy in the researcher (2005). Madill and Gough also argue that the internet offers an important source of archival data for contemporary research (2008). In the case at hand, the internet and other technology played a crucial role in the development and execution of the New York Tribunal. Healy argues that recent technological advances provide more opportunities for international sharing and exchange (2001). Ife identifies the development of a new, network-based society as the result of increased global interdependence. He argues that "the network society will have serious consequences for inequality and social justice" (2000, p. 54). McRae, too, contends that the internet and other interactive technologies have made crucial differences for civil society movements in that they have accelerated the timescale for achieving movement objectives, and in that they offer the potential for a global support base (2001).

I agree with these researchers about the potential important contribution of internet and popular media in the promotion of social change. It should also be noted that technological advances, particularly including the internet and other communication media, are playing a growing role in the pro-democracy movement inside Burma. Most recently, during the 2007 Saffron Revolution, these technologies provided the world with images, videos and accounts of the events of the massive pro-democracy protests as well as the brutal government response. Online and other communication media tools have the potential to give voice to a wide diversity of people. They also provide an inexpensive method for the rapid dissemination of information and advocacy messaging. 
Therefore, I believe it is important to recognize the increasing role of these technologies in civil society movements and to take them into consideration in social work research.

\section{DATA ANALYSIS}

Like my data collection, the data analysis for this thesis project is entirely qualitative. I believe that this approach is more fitting for the complexity of the topics at hand. According to Yegidis, Weinbach and Morrison-Rodriguez, feminist research is “designed to bring about change in women's lives by confronting sexism and attempting to alter those social institutions that may promote or perpetuate it" and "is used to validate women's lives and experiences" (1999, p. 143). Similarly, Schwartz and van de Sande write that "just as social work is committed to social justice and social change, the aim of social work research should be the same" (forthcoming, p. 1). It is from this perspective that I approach this thesis research.

Madill and Gough describe the "instrumental method" of qualitative data analysis as distinguished by its commitment to a particular "research ethos or philosophical perspective", even as it draws on a variety of analysis methods (2008, pp. 258-259). In case study research, Yin refers to this as "analytic generalization", wherein the results of a case study are compared to a previously developed theory (2009). In this thesis project, I have conducted analyses of both the Tribunal testimonies as well as the Tribunal outcomes, while framing these methods in an over-arching theoretical commitment - to utilizing a feminist lens and to promoting social justice through research. 
Given that the voices of the women of Burma are too often marginalized, I strive to present as much of their stories as possible and to root the discussion firmly in women's experiences. As noted above, I was able to observe the New York Tribunal and transcribed recordings of the Tribunal proceedings. Part of my data analysis involves the thematic analysis of the content of this transcript (see Chapter 5). Rubin and Babbie cite Glaser and Strauss" conception of "analytic induction", wherein qualitative analysis begins with observations, then moves to finding patterns and relationships between variables $(2005$, p. 477). This is the model of analysis used in examining the Tribunal transcript. Indeed, for the purposes of this thesis, my analysis began with observation of the Tribunal itself, and then moved to a thematic analysis of the Tribunal transcript, seeking to identify themes which emerged, both within and across the three testimonial sections - violence against women; civil and political violations; and economic, social and cultural violations.

These observation notes and thematic analysis of the Tribunal testimonies complement the thematic analysis of a variety of other documents and internet-based material, the collection of which is outlined above. I explore both the political outcomes of the International Tribunal on Crimes Against Women of Burma, as well as its outcomes for civil society. Political outcomes include such things as high-level governmental meetings on Burma which arose following the Tribunal, or the fulfillment of any of the New York judges' recommendations to the regime in Burma, the United Nations, or the international community. 
I also assess the ways in which the New York Tribunal was utilized as an advocacy tool by non-governmental organizations. In order to evaluate the advocacy outcomes of the New York Tribunal, I examine a variety of documentation from the broader Burma advocacy network following the Tribunal. In this way, I aim to determine the ways in which this event has been used as an advocacy tool. Examples of the use of the New York Tribunal as an advocacy tool include the dissemination of the Tribunal webcast, findings, or final report in an organization's website or newsletters; media stories written about the Tribunal or in which the Tribunal and its findings are referenced; or civil society letters to UN or other governmental officials which reference the Tribunal and its findings. I also explore how information about the Tribunal and its findings is disseminated through a number of popular social media portals, including YouTube, Facebook, and Twitter. Indeed, each of these examples constitutes a way in which the messages of the Tribunal and the voices of the women of Burma may be spread to a broad international audience, including both governments and the public.

\section{USING A FEMINIST FRAMEWORK}

This thesis project recognizes the ongoing gender inequality in Burma, and around the world, and will therefore focus in particular on the experiences of the women of Burma. It will seek to give voice to the women of Burma and to break the silence that has been forced upon them for so long in part because they are women. Furthermore, this thesis project aims to explore the ways in which the International Tribunal on Crimes Against Women of Burma contributed to advocacy efforts for justice for the women of 
Burma, and to determine the potential role of women's tribunals in future advocacy efforts. In all of these ways, this thesis will be guided by a feminist theoretical lens. Porter argues that feminist international relations theory has provided a critique of the "masculinist limitations" of mainstream international relations, and has worked to develop alternatives to compensate for the previous marginalization of women's voices on the international stage $(2007$, p. 7$)$. Women's tribunals, such as the one forming the focus of this thesis, may offer one such alternative. In highlighting women's voices, I recognize that women know what is needed for their safety and security, as well as what is required to achieve justice for the crimes perpetrated against them. In this way, this work reflects what Porter calls "feminist ethics" (Ibid, p. 37).

Reilly emphasizes the need for a feminist framework which does not assume that women are united by a common gender identity or experience of patriarchal oppression across boundaries. She notes that gendered disadvantage is experienced differently across other boundary lines. In other words, while women may be united by the fact that they face patriarchal oppression, it cannot be assumed that they experience it the same way. It also cannot be assumed that gender is the most important factor contributing to a woman's oppression. Reilly therefore emphasizes that the content of universal human rights must resonate with the diverse experiences of women (2007). Denov and Gervais argue that, too often, images of women in war are simplified images of women as passive victims, peacemakers, mothers and wives. In these images, men are depicted as the true participants of war. However, girls and women have multi-dimensional roles in armed conflict (2007). 
Postmodernist feminist Flax emphasizes the importance of exploring not only the existence of difference, but also how those differences are reproduced and maintained. This is related to Foucault's assertion that the production of discourse is inseparable from the exercise of power (Posel D. , 2008; Fawcett \& Featherstone, 2000). Indeed, postmodern feminists stress that categories are not fixed, but are flexible and changing (Fawcett \& Featherstone, 2000). For example, Posel argues that in the case of the South African Truth and Reconciliation Commission, victimhood did not equate with passivity. Rather, the act of speaking out worked to repair damage both internally and externally (2008).

Throughout this thesis project, I am guided by a postmodern feminist framework in my aim to root the discussion in the diversity of women's experiences. I emphasize that women are not only victims, but are also agents and survivors of armed conflict. Foucault argues that power is not only situated in one place, but is instead exercised by all. He contends that power relations always contain the possibility of resistance, which may occur at multiple points (Fawcett $\&$ Featherstone, 2000). For the purposes of this thesis, it is important to recognize the power exercised in both the marginalization of women's voices in regard to human rights violations, as well as in the resistance of oppression that is at the core of the popular tribunal process.

\section{LIMITATIONS OF THIS STUDY}

While a study's limitations are often addressed in its conclusions, I believe it is important to highlight the limitations of this study from the start so that they do not 
distract my reader from the discussion at hand. First and foremost, my language abilities are limited solely to English. This was particularly a limitation to finding information about the Tribunal and its impacts in Burma. While I believe that the information I was able to document effectively answers the research questions of this thesis project, having information in other languages (particularly Burmese and Thai) would have added to the data.

Second, this thesis project was completed under a limited timeframe. This meant that the case study at hand had to be defined narrowly. Given the slow-moving nature of political outcomes, in particular, this constituted a limitation for this study. It would have been interesting, for example, to be able to include a discussion of the outcomes of the Tribunal film release in September 2010, as well as to explore the advocacy surrounding the national elections in Burma in November 2010. Again, though I believe that the data collected within the timeframe of the case study sufficiently addressed my research questions, a longer case study period would have likely led to more data.

\section{TERMINOLOGY}

Before beginning this thesis discussion, it is important to make a few points regarding the language used in this paper. First, I should specify what I mean when using the terms 'war' and 'armed conflict'. Cockburn outlines a widely agreed upon definition of war as including the following elements: the conflict is collectively organized; it involves weapons and is potentially deadly; the conflict is fought for a purpose or with a particular interest; and most importantly, the conflict is socially sanctioned so that any killing is not considered murder $(2007$, p. 232). For the purposes of this paper, I utilize 
this definition of war, and use the terms 'war' and 'armed conflict' interchangeably, as both fit this criteria. Similarly, though the ongoing conflict in Burma has not officially been deemed a "war", it is nonetheless aptly described by Cockburn's definition.

Second, it should be noted that throughout this paper I refer to the country now officially called 'Myanmar' as 'Burma'. The country's name was changed by the military regime in 1988. I use the name Burma in solidarity with the nation's pro-democracy activists, for whom the military junta's authority, and therefore its renaming of the country, remains illegitimate.

Finally, I consistently refer to those women who testified at all three women's tribunals as 'testifiers', rather than as 'witnesses'. The use of this terminology, a deliberate choice on the part of tribunal organizers, emphasizes the agency of women in their speaking out and demanding accountability, rather than painting them as passive victims of the crimes perpetrated against them. Having clarified this terminology, we can now turn to the discussion of the International Tribunal on Crimes Against Women of Burma.

As social workers dedicated to the pursuit of social justice for all, our world is getting smaller and smaller. It is my belief that interventions and advocacy which cross and transcend national boundaries will become increasingly common as our world becomes ever more deeply interconnected. Initiatives such as the International Tribunal on Crimes Against Women of Burma provide important opportunities for social justice advocates to show solidarity with oppressed peoples throughout the world. We turn now to the case study at hand for further insight into as to how this may be accomplished. 
Chapter 2: The Crises in Burma 


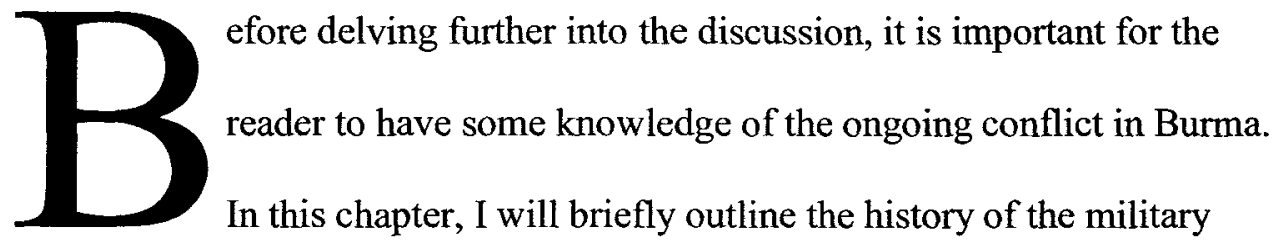

regime as well as of the massive pro-democracy protests which have taken place in opposition to the junta's rule. I will also offer some background information regarding the human rights violations addressed by testifiers at the New York Tribunal - sexual violence against women, civil and political violations and social, economic and social violations. This chapter will by no means constitute a comprehensive overview of the crises in Burma, but is meant to provide the reader with the background knowledge necessary to better understand the remainder of this thesis.

\section{BRIEF HISTORY OF MILITARY RULE \& PRO-DEMOCRACY PROTESTS}

Chinkin describes the nature of the "new wars" that are increasingly common around the globe, which she argues poses challenges to international humanitarian law:

Today's conflicts... are most frequently fought within states. Direct fighting between identified sides is rare; rather there are long-term campaigns of terror and attacks on towns and villages, typically with small arms and low technology weapons. Violence and the very goals of fighting are directed at the civilian population, predominantly women, children and elderly men. Ethnic cleansing is pursued through the commission of gross violations of human rights and the spread of terror. There is a high level of population displacement, causing disruption to the provision of essential services. Criminalization and war have become inextricably entwined, for example through the looting of humanitarian and military supplies, drug trafficking and illegal sales of the resources that maintain the conflict (2004, pp. 120-121). 
This description aptly fits the ongoing crises in Burma. Since a coup against the postcolonial democratic government in 1962, Burma has been ruled by an illegitimate military junta, the State Peace and Development Council (SPDC). The people of Burma have repeatedly called for regime change, through massive public demonstrations and numerous individual acts of resistance.

In 1988, a popular uprising began with university students and spread throughout the country before being met with a violent government crackdown in which thousands were killed and many imprisoned (Havel \& Tutu, 2005, p. 2). These protests ultimately culminated in free national elections in 1990, in which the opposition National League for Democracy party (NLD), led by Aung San Suu Kyi, won a landslide victory - about $80 \%$ of the vote. However, the junta refused to recognize the results and imprisoned Suu Kyi along with many other NLD leaders and NLD-elected Members of Parliament.

In response to a rapid increase in poverty resulting from the ongoing collapse of Burma's economy, monks and nuns led massive street demonstrations in the fall of 2007, in what became known as the "Saffron Revolution". Once again, these protests were crushed in a brutal crackdown by the military regime. In fact, in August and September 2007 alone, at least 227 demonstrations took place against the regime, across at least 66 cities. During this period, hundreds of protestors were killed and at least 3000 monks and civilians were detained and tortured (Women's League of Burma, November 2007, p. 2). According to Human Rights Watch, as of January 2010, more than 230 Buddhist monks involved in the Saffron Revolution remained imprisoned (2010, p. 2).

The situation worsened when Cyclone Nargis struck the Irrawaddy Delta in May 2008, 
leaving hundreds of thousands of people in complete devastation. In fact, Amnesty International estimates that approximately 2.4 million people were affected by Cyclone Nargis. More than 84,500 people died and more than 19,000 were injured, with thousands unaccounted for (Amnesty International, 2009). The military junta blocked the free flow of humanitarian aid to the people of Burma following the cyclone, and pressed forward on a referendum on a new draft constitution.

This new constitution effectively entrenches military power in Burma by mandating that $25 \%$ of all parliamentary seats, as well as significant portions of the executive and judiciary, must be filled by military personnel. The new constitution also requires the country's president to have military experience. These provisions significantly hinder women's representation in Burma's parliament, and effectively bar women from the presidency. The constitution itself was also only published in the majority Burmese language prior to the referendum (Ibid). Given the abuses perpetrated particularly against ethnic minority groups in Burma, this further emphasizes the junta's staunch opposition to genuine political dialogue.

The months leading up to the referendum were also rife with government corruption and repression of the people of Burma. In February 2008, the Burmese regime issued the Referendum Law for the Approval of the Draft Constitution, which provided for a prison term of up to three years and/or a substantial fine for anyone caught campaigning against the referendum. This law was used to detain many activists peacefully campaigning against the constitution or calling for a boycott. In one example, over 70 people were arrested in late April 2008 for trying to stage a peaceful demonstration (Ibid). The 
referendum on the draft constitution passed in May 2008, under circumstances which were widely thought to be corrupt. While the government claimed that 98.1 per cent of

eligible voters had voted during the constitutional referendum, and that 92.4 per cent of these were in favour of the draft constitution, their refusal of international monitors, combined with their brutal repression of the people and the devastation of Cyclone Nargis, resulted in widespread suspicion both in Burma and internationally (Amnesty International, 2009).

Similarly, the national elections held in fall 2010 are largely seen as illegitimate, both within Burma and around the world. A number of senior regime officials resigned their military posts in order to run for office as "civilians". There is great concern that the 2009 arrest and trial of Aung San Suu Kyi, widely regarded as politically-motivated, further confirms the regime's unwillingness to allow genuine political dialogue and democracy (Human Rights Watch, 2010). In May 2010, the NLD decided to disband rather than ratify election laws that they feared might put them under the regime's control.

\section{HUMAN RIGHTS VIOLATIONS IN BURMA}

Human rights violations in Burma are among the world's most severe. Despite continued pressure within Burma and recent international pressure, particularly from the United States and the United Kingdom, the military junta remains unwilling to recognize the democratically-elected government, or to address the dire human rights situation inside the country. Instead, Amnesty International reports that the Burmese 
government's development of natural gas, hydropower and oil projects in partnership with state-owned and private firms has led to a range of human rights abuses (2009).

According to the Women's League of Burma, under the pretext of "national security", the SPDC now commands almost half a million troops, which makes it one of the largest armies in Southeast Asia. The people of Burma continue to be suppressed by soldiers, riot police, special police and regular police forces (Women's League of Burma, November 2007 , p. 1). It should be noted that oppression at the hands of the military regime is not reserved only for political activists, but also consistently spreads to the civilian population across the country.

\section{SEXUAL VIOLENCE AGAINST WOMEN}

At the United Nations, the women always hear about how women in Burma are equal because they have the right to own property. But the women are being raped every day. We don't want to own property - we only want to own our own bodies. We can't even own our own bodies in Burma. - Woman activist speaking to an international delegation (Nobel Women's Initiative, 2008, p. 14)

The Women's League of Burma has noted that in Burma, "society is dominated by the army, which is made up almost entirely of men. This has reinforced the existing patriarchal system and women human rights defenders are easily targeted" (November 2007, p. 1). Indeed, women human rights defenders are more at risk for certain violences and restrictions - they face exclusion, prejudice, rape, sexual assault and public humiliation. During the brutal military crackdown on the Saffron Revolution, for example, special riot police were authorized to commit gender-based violence against protestors in various parts of Rangoon without fear of prosecution or punishment (lbid). 
As with the other human rights violations in Burma, however, sexual violence is not reserved to political dissidents, but is used as a deliberate tactic of civil war to humiliate and terrorize the civilian population as well. In June 2002, the Shan Women's Action Network and the Shan Human Rights Foundation released a report entitled License to Rape. This report documented 173 incidents of sexual violence involving 625 women and girls, committed by the Burmese army in Shan state between 1996 and 2001 alone (Shan Women's Action Network, 2009, p. 11).

Widespread sexual violence against women and girls continues to the present. Many women and girls taken by the army as porters are subjected to rape, gang rape and other sexual harassment (Karen Women's Organisation, February 2007). In his 2008 report to the UN Security Council pertaining to Security Council resolution 1820 , which condemns the use of sexual violence in armed conflict, UN Secretary-General Ban Ki-moon noted:

In Myanmar, recent concern has been expressed at discrimination against the minority Muslim population of Northern Rakhine State and their vulnerability to sexual violence, as well as the high prevalence of sexual violence perpetrated against rural women from the Shan, Mon, Karen, Palaung and Chin ethnic groups by members of the armed forces and at the apparent impunity of the perpetrators. (United Nations Security Council, 20 August 2009, p. 7)

Survivors of sexual violence at the hands of the military regime have few places to turn. As one female protestor noted in regard to the official Women's Affairs associations in Burma, "No one wants to contact them if there is a problem because they are the wives of the PDC (Peace Development Council), so they are the same feathers" (Women's League of Burma, November 2007, p. 19). However, the women of Burma have taken it upon themselves to respond to this absence of justice. Despite the threat of government 
repression, a large number of Burmese women's organizations have arisen at the grassroots level, particularly among the refugee populations in Thailand and other places, to document sexual violence against women and provide supports to survivors. The 12 member organizations of the Women's League of Burma are examples of these organizations.

\section{CIVIL AND POLITICAL VIOLATIONS}

I don't know why they came to arrest me. I just shouted 'not to kill the monks'. This is a violation of my basic rights. - Khin Mar Htwe, female protestor (Women's League of Burma, November 2007, p. 18)

As described above, the Burmese military regime has consistently responded to pro-democracy activism with brutality. The continued government repression of political dissidents in Burma has led to the detention of a large number of political prisoners. Most famous among these is Aung San Suu Kyi, who remained under house arrest for fourteen of the past twenty years. Until recently, she was the world's only imprisoned Nobel Peace Laureate, but is far from Burma's only political prisoner.

The military regime's campaign against pro-democracy activists has intensified in recent years. In fact, as of early December 2009, the Association for the Assistance of Political Prisoners (Burma) reports that there are 2173 known political prisoners in Burma (2009). This number represents more long-standing political prisoners in jail than at any other time since the pro-democracy protests in 1988; it is nearly double the number in prison in 2007 (Amnesty International, 2009). 
Since the 2007 Saffron Revolution, monasteries and the homes of protestors have repeatedly been raided. Female family members of activists have been arrested and detained, sometimes leaving children without caretakers (Women's League of Burma, November 2007). The Women's League of Burma reports that there has also been an increased criminalization of women activists following the Saffron Revolution (lbid). Many activists have been sentenced by unfair trials in closed courts, and are kept in prisons with poor health and sanitation facilities. The International Committee of the Red Cross continues to be denied access to Burmese prisons and detention facilities (Human Rights Watch, 2010).

In addition to these abuses, activists have often been the targets of military smear campaigns over state-controlled media. At times they have even been branded as terrorists. In one example, after publishing the above-mentioned License to Rape report, members of the Shan Women's Action Network were defamed regularly by the government. In state media, the authors of the License to Rape report were repeatedly called "terrorists" and "drug-trafficking insurgents" (Shan Women's Action Network, 2009 , p. 13). One 2006 SPDC publication denying the army's involvement in sexual attacks was entitled Licensed to Lie (Ibid, p. 31).

The regime also claimed that male opposition leaders had masterminded the report with the women authors as their "puppets". The Shan Women's Action Network has noted, "This was an insult not only to our own integrity and ability, but that of all women of Burma" (Ibid, p. 13). Furthermore, the Burmese regime pressured Thai authorities to take action against those involved in the publication of License to Rape. As a result, the 
Shan Women's Action Network and the Shan Human Rights Federation were forced to close their offices in September 2002. Fortunately, they later managed to re-open them (Shan Women's Action Network, 2009).

\section{SOCIAL, CULTURAL AND ECONOMIC VIOLATIONS}

Here in Burma, all people in the grassroots have been facing tremendous hardship to fulfil their basic needs: food, clothing, shelter and education... Things are OK for those who can 'pay' and bribe... Money is everything. - Khin Hnin Tha, female protestor (Women's League of Burma, November 2007, p. 19)

In addition to the abuses above, extrajudicial killings, forced labour and the confiscation of land and property are widespread in Burma (Human Rights Watch, 2010; Nobel Women's Initiative, 2009b; Nobel Women's Initiative, 2008; Amnesty International, 2009; International Human Rights Law Clinic at Harvard Law School, 2009). As a result of government oppression, the majority of ethnic groups live with limited access to food, health care and education (Nobel Women's Initiative, 2009b). According to Human Rights Watch, the military routinely targets food production and the means of civilian livelihoods in its attacks (2010).

Since 1996, the military has destroyed over 3,000 villages. In May 2009, for example, attacks by the military and its proxies displaced thousands of civilians and sent 5000 refugees into neighbouring Thailand. In July of the same year, Burmese army troops perpetrated attacks against 39 villages in Shan state, displacing approximately 10,000 civilians (Ibid, p. 2). Forced relocation is also a standard practice of the regime in 
making way for hydropower and natural gas projects, the profits of which stay with the military junta.

Forced labour is an ongoing and well-documented violation of human rights in Burma. In June 2010, the International Labour Organization (ILO) noted in its assessment of the situation in Burma "well-documented allegations that forced and compulsory labour continued to be exacted from local villagers in 2009 by military and civil authorities and to have occurred in all but one of the country's states and divisions" (International Labour Conference, 99th Session, June 2010, p. 4). This forced labour took a wide variety of forms and involved a variety of tasks, including: forced portering for military personnel; prison labour; construction and maintenance of army camps; construction of bridges and roads; confiscation of food supplies and extortion of money; forced sentry duty; and human minesweeping (Ibid). Also included among forced labourers in Burma are an estimated 70,000 child soldiers, representing $30 \%$ of the Burmese military and the largest number of child soldiers in the world. Efforts to curb the recruitment of child soldiers have been mainly cosmetic, and, as with so many human rights violations in Burma, perpetrators act with impunity (Human Rights Watch, 2010).

Widespread human rights abuses have led to massive displacement of people, both within and beyond Burma. Human Rights Watch estimates that there are half a million internally-displaced persons in eastern Burma. Despite a large resettlement program by international agencies, there are also 140,000 refugees living in nine camps along the Thailand-Burma border. More than 50,000 refugees from Chin state are still in eastern India, and 28,000 ethnic Rohingya Muslims live in refugee camps in Bangladesh (Ibid, p. 
3). Of course, these numbers do not account for the migrants, asylum seekers and refugees spread throughout Thailand, India, Bangladesh, Malaysia, and around the world. In fact, over one million refugees have fled Burma in search of asylum (Nobel Women's Initiative, 2009b, p. 14).

The situation in Burma undoubtedly constitutes a grave humanitarian and political crisis. As noted previously, this chapter has not been meant to serve as a comprehensive discussion of the human rights violations which are rampant in Burma. Instead, it has aimed to provide the reader with necessary background on these violations in the context of this discussion of the International Tribunal on Crimes Against Women of Burma. Before delving into the exploration of this and other women's tribunals, however, it is important to first ask how we understand these violations against women. I will now turn to a discussion of the theoretical framework guiding this paper. 
Chapter 3: Theoretical Notes 


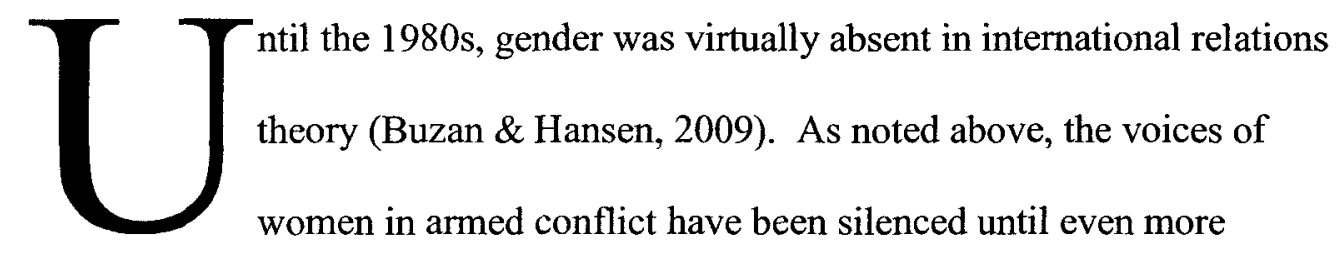

recently, and continue to be marginalized in many arenas. In this chapter, I seek to provide a deeper understanding of violations against women during wartime. I examine the nature of women's experiences of armed conflict, including the multiple violences women experience and the factors contributing to this violence, the exclusion of women from peace processes and their views of what is required for sustainable peace. Finally, this chapter will highlight women's resiliency in the face of armed conflict, such as the armed conflict in Burma.

\section{THE NATURE OF WARTIME VIOLENCE AGAINST WOMEN}

Women's bodies have actually become battle grounds...the violence is all about destroying... the inbuilt strength of a woman to build a community - Ruth Ojiambo Ochieng, Uganda, 2006 (Shepherd, 2008, p. 1).

UNICEF estimates that since World War II, 90 percent of the victims of armed conflict have been civilians, largely including women (Brunet \& Rousseau, 1998, p. 36). The UN also estimates that $70-80$ percent of the world's refugees are women (lbid., p. 40). This situation makes women and children particularly vulnerable to violence and to sexual exploitation in exchange for survival goods (Coomaraswamy, 2005, p. 59). Indeed, as has become increasingly clear, sexual violence is prominent among the violations suffered by women during wartime. Sexual violence may include rape, sexual 
slavery (including forced 'marriage'), sexualized torture, forced impregnation or sterilization, or forced prostitution.

Across boundaries of culture, religion, political ideology, foreign allies and modes of warfare, rape is perpetrated by men who view themselves as soldiers (Enloe, 2000, p. 134). In such militarized rape, the female body is a spoil of war. Rape has been used to militarize women under regimes as a measure of 'national security'. Systematic rape has also been part of campaigns of ethnic cleansing, as women are seen to have the potential to bear 'enemy sons' (Enloe, 2000). Women may also face violations in the form forced prostitution or 'voluntary' relations with a soldier, refugee camp guard or peacekeeper (Brunet \& Rousseau, 1998). Rape has been used to bring women to support certain causes and to provoke men to avenge women (Enloe, 2000).

Though Enloe identifies a number of types of military rape, including recreational rape, national security rape and systematic mass rape, she also highlights features which are common amongst them. First, she argues that in militarized rape, the militarized male rapist imposes his understandings of 'enemy', 'soldiering', 'victory' and 'defeat' on both the individual woman and on the act of sexual assault itself. Second, Enloe argues that militarized rape is harder to privatize than non-militarized rape because its rationale is drawn from the broader social context. Finally, she argues that the woman assaulted in militarized rape must relate her response to her assault to collective memory and to collective ideas regarding national destiny (Ibid, pp. 110-111).

Women in armed conflict are also subjected to forms of torture which are different from those experienced by men (Edwards, 2006; Enloe, 2000; White, 2007). Indeed, White 
argues that torture techniques have different meanings for men and women, as torturers rely on women's culturally-rooted notions of shame and honour (White, 2007). Torturers intertwine popular notions about feminine sexual purity with their own ideas about 'the enemy' and about themselves as masculinized, militarized protectors of the state. Militarized rape is often a form of torture. In torture rape, the perpetrator's purpose is to rob the woman prisoner of her self-respect, dignity, and even her identity (Enloe, 2000).

Forced prostitution provides another example of sexual violence against women in war. Enloe describes the ways in which there is a false separation of militarized rape and militarized prostitution, allowing officials to view the perpetrators and victims of these acts differently. At the same time, however, militarized prostitution is sometimes seen as a safeguard against militarized rape. Indeed, many soldiers view prostitution as a routine recreational activity. In this way, the two acts can be seen as interconnected (Ibid).

It should be noted that women are not always civilians in armed conflict, but can also be found amongst the ranks of armed forces. In these roles, women combatants may be subjected to sexual duties or forced marriage (White, 2007). Indeed, women's experiences of participation in armed groups differ significantly from those of men. The absence of men during armed conflict often heightens insecurity and risk for both women and children (Lindsey, 2005). In addition to the threat of sexual violence in their home communities or in refugee camps, girl children are also sometimes at risk of being 'recruited' to join armed groups. Children are often recruited by these groups, (including by official state militaries), specifically because they are easier to indoctrinate and intimidate, and are less likely to question those in authority over them (Baines, 2009). 
Girl children in these situations often face sexual violence. Throughout the war in Sierra Leone, for example, girls were systematically abducted by armed groups and forced into roles as combatants, wives, commanders, slave labourers, or a combination of these (Denov \& Gervais, 2007). Lindsey notes that while the number of women combatants is increasing, the majority of women still experience the impact of armed conflict as members of the civilian population (2005).

Victims of sexual violence during wartime face both limitations in access to medical care, as well as more serious health concerns. They rarely receive effective treatment immediately following their assault, and may suffer horrible wounds requiring surgery; such complications are particularly a concern for very young girls. Of course, pregnancy and sexually transmitted diseases, including HIV/AIDS pose other concerns (Coomaraswamy, 2005). It has been estimated that, between 1991 and 2001 alone, tens of thousands of children have been born as a result of mass rape or of sexual exploitation and abuse during wartime. These children, born of war, often face discrimination, stigma and even infanticide (Carpenter, 2007, p. 2).

It is important to note that war is often not over for women when formal peace accords are signed. This is especially the case for women who continue to experience violence in both the public and private spheres. Indeed, militaristic attitudes can fuel domestic abuse both during and after armed conflict (Enloe, 2000). In addition, after the cessation of the formal war, women are often expected to return to their traditional roles, regardless of the roles they may have played during the conflict (White, 2007). Many women survivors of 
sexual violence also continue to suffer intense shame and fear, and are ostracized by their own communities. Bunch and Reilly note:

Unlike men who, in times of war, are often publicly valorized for the violence they endure (or commit) for their country, the violence levied against women is either made invisible or is seen as a source of shame for the women and as a constant reminder of the conquest of the nation $(1994$, p. 38).

\section{FACTORS CONTRIBUTING TO WAR TIME VIOLENCE - UNDERSTANDING VIOLATIONS AGAINST WOMEN}

Shepherd argues that violence produces gender both as an organizing conceptual category and as a lived identity (2008). Fung notes, "Conflict exacerbates existing inequalities within societies and, as a result, has a disproportionate impact on the least powerful and most vulnerable members of society" (2005, p. 226). Women, by virtue of their disadvantaged position in society, are therefore put at disproportionate risk during times of conflict. Denov and Gervais argue that in the Sierra Leonean case, economic insecurity and corruption exacerbated women's vulnerability. They describe how insecurity in Sierra Leone was gendered through "the transposition of patriarchal power structures onto a militarized terrain", so that traditional gender roles were entrenched in the daily practices of conflict (2007, p. 894). This transposition of unequal gender relations onto armed conflict can be seen across the world, especially in regards to sexual violence. Sajor argues that violence against women cannot be understood separately from patriarchy in society. She views war as an inherently patriarchal activity, involving the domination of men over women in both public and private spheres (1998). 
Brunet and Rousseau agree that the defining characteristic of violence against women is that it is perpetrated on women by virtue of their gender and sex (1998). Indeed, violence and armed conflict have long been fought on women's bodies. McClintock argues that women were the boundary markers of imperialism and suggests that imperialism involved a long tradition of male travel as an "erotics of ravishment" (1995, p. 22). Lindsey confirms, "Women have been targeted precisely because they are women...because they are perceived as symbolic bearers of the future of their cultural and ethnic identity and as responsible for future generations of their community" (Lindsey, 2005, p. 23). In the context of this thesis, it should be noted that testimonies at all three women's tribunals have also pointed to this targeting of women as women.

Enloe argues that national security rape is an authorized public act aimed at pushing women back into traditional roles. Patriarchal ideas about what constitutes a 'respectable' woman are used both in selecting women for attack or for arrest and torture, and in deeming a woman bringing forth rape charges as believable or unbelievable. In many cases, a 'respectable' woman is one who upholds national security by refraining from political activism and guarding her sexual purity (2000). Sexual violence is thus directly connected to women's roles as women within their communities.

Radhika Coomaraswamy, the first United Nations Special Rapporteur on Violence Against Women, describes how in conflicts between ethnic groups, rape and sexual violence are also used to mark boundaries between communities: "By raping the other, one searches for purity, certainty and distance from the other, who then becomes merely the object of violence" (2005, p. 55). As mentioned above, sexual violence during 
wartime takes place across boundaries of all kinds. Furthermore, it is important to note that often the arrival of peacekeeping forces does not end, but exacerbates, sexual violence against women (Porter, 2007). These facts point to patriarchy and gender inequality as a prime contributing factor to wartime sexual violence.

Patriarchal ideology and social structures can also be seen in many nationalist and militarist discourses. In fact, White argues that most nationalisms are patriarchal in nature. She emphasizes that colonial oppression worked to diminish the status of women in complex ways so that anti-colonial nationalisms often induce nostalgia for a romanticized past in which men had control over both the land and the women (2007). Indeed, in many nationalist discourses, a woman's primary role is that of mother, reproducing both the nation and national ideals and values (Shepherd, 2008).

Of course, military forces are also not gender neutral. Military organizations and militarist discourses work to produce gender identities which are consistent with patriarchal ideology and practice (White, 2007). Enloe notes that when military institutions are largely male, as is the case in Burma, masculinity becomes tied to the state (2000). White further argues that the "narrow militaristic interpretation of equal rights paves the way for the marginalization of women after the war" $(2007$, p. 875). Therefore, the entrenchment of gender divisions during conflict may work to perpetuate inequality once the fighting has stopped. Indeed, in the post-conflict process, gender relations are often avoided as a divisive issue in the context of national security. Refrains of 'peace first, then equality' are all too common. 
In addition to patriarchy and nationalist/militarist discourses, I must acknowledge one more contributing factor to gender-based violence against women in war and armed conflict: gender-based violence against women is a deliberate weapon of war. As will be noted in Chapters 4 and 5, women's testimonies in popular tribunals in Vienna, Tokyo and New York demonstrate that women's bodies are figuratively and actually the site of combat in war time. Furthermore, these testimonies show that rape and violence against women are often integral aspects of military strategy (Bunch \& Reilly, 1994; McDonald, Argibay, Chinkin, \& Mutunga, 2001; Nobel Women's Initiative and Women's League of Burma, 2010). Indeed, Enloe writes, "The woman who endures a militarized rape has more than one man to accuse" $(2000$, p. 141).

Violations against individual women cannot be viewed in isolation from one another. Instead, these violations are often systematic occurrences which are not random but fall into a pattern. As Enloe notes in one example, "The widespread occurrence of national security rape in the Philippines...was not merely the result of amorphous, pre-political cultural tendencies. It was the product of decisions" (2000, p. 127). Indeed, militarized rape is rarely an isolated act, but occurs on a widespread basis within structured relationships (Ibid). Brunet and Rousseau confirm, "Civilians are thus targets of and pawns used in war strategies, not the accidental victims of combat" $(1998$, p. 36). The recognition that violations of women's human rights are the result of deliberate policy choices is essential as we move forward in our discussion regarding the pursuit of justice for the women of Burma. 


\section{WOMEN'S VISIONS OF SUSTAINABLE PEACE}

There is no peace without justice, and there will be no justice without democracy - Katana Gégé Bukuru, Democratic Republic of Congo, 2009 (Nobel Women's Initiative, 2009b, p. 32).

As discussed above, war is not always over for women when the formal violence ends and peace accords are signed. Women repeatedly indicate that peace must be built on more than formal negotiations and agreements. Okinawan women, for example, have long strived to critique the impact of militarization on women's lives and to make visible the connections between specific incidents of rape and broader patterns of misogyny and violence against women which are integrated into militarism (Enloe, 2000). Similarly, Chinkin argues that findings such as those of the Women's International Tribunal on Japanese Military Sexual Slavery point to important lessons regarding the continued links between militarism and sexist attitudes which contribute to the abuse of women (2001).

Porter suggests that women should be included in all stages of peace processes, not only because they are affected by conflict and peace agreements, and not only because their participation is essential to the realization of inclusive social justice, but also because women bring different kinds of issues to the table in formal peace negotiations. She explains, "How many women understand peace processes differs from the norm typically it includes attending to practical material needs that further a sense of security. It is hard to feel secure if you are starving... or your water source [has been] polluted" (2007, p. 26). Indeed, Porter argues that women tend to have an understanding of the root causes of conflict, and tend to prioritize issues such as healthcare, education, nutrition, childcare, and human welfare needs in peace negotiations (Ibid). 
Buzan and Hansen contend, "State security is supposed to provide security for all citizens, yet there is a gendered difference in how men and women are affected and what problems are considered 'proper' security problems" (2009, p. 140). Denov and Gervais similarly argue that gender shapes the way that security is envisioned, experienced and ensured (2007). In Sri Lanka, a June 2002 subcommittee on gender issues, formed jointly by the government and the Liberation Tigers of Tamil Elam, recommended a number of focus areas for conflict resolution. These included the provision of food, housing, clean water, healthcare, education, trauma counselling, the economic and social rights of women, addressing the issue of human trafficking, and addressing the needs of war widows and the families of detainees, the disappeared and of soldiers (Porter, 2007, pp. 186-187).

Moussa argues that those focusing on long-term security and stability place a higher value on economic and societal elements of development, rather than on the mere end to formal violence. She further argues that gender equality is a prerequisite for achieving security (2008). Post-conflict economies are often characterized by high rates of poverty and unemployment, as well as the disruption of production and markets (Pugh, 2007). Widows and relatives of those who are missing during and after the conflict may be left without rights to land, homes, inheritance, and social assistance (Lindsey, 2005). We will see later that the struggle to fulfil basic needs for themselves and for their families also constituted a central part of the experiences described by the women of Burma who testified at the New York Tribunal. As Porter writes, "In attending to these complexities [of modern war], the interdependence between gender equality, social justice, sustainable development and peacebuilding cannot be overstated" (2007, p. 12). 
In discussing women's views of what is required for sustainable peace, it should be noted that women are largely excluded from peace processes around the world. Anne Marie Goetz of UNIFEM describes peace negotiations as a "last bastion of exclusive decisionmaking" (Nobel Women's Initiative, 2009b, p. 16). In fact, at an international women's conference, entitled Women Redefining Democracy, Goetz demonstrated that women have made up an average of only 5.9 percent of negotiators in formal peace processes since 1992 , and an average of only 2.43 percent of signatories to these peace accords (The good, the bad and the ugly about democracy for women, 10 May 2009). Sexual violence and sexual slavery are also routinely discounted in peace settlements (Chinkin C. M., 2001). As one participant at the Women Redefining Democracy conference articulated, all too often, peace negotiations involve men forgiving men for things men have done to women (Nobel Women's Initiative, 2009b).

\section{RECOGNIZING WOMEN'S RESILIENCY}

You see the... women as victims of war and conflict. Indeed, that they are. But they also are the ones most potentially able to be the peacemakers and the developers of their country - M. Asha Samad, Somalia, 1993 (Center for Women's Global Leadership, 1994, p. 29).

As noted earlier, women's experiences of armed conflict are often simplified and marginalized. Shepherd criticizes some violence against women literature for denying women agency and representing women (and children) as a singular category made up of eternal victims. Such a conceptualization of women in war not only does not allow for women's agency, but also discounts the fact that the majority of men do not perpetrate 
violence against women (Shepherd, 2008). In fact, women and girls exercise agency and resistance both during times of armed conflict and after the formal violence has ended, as survivors. Women are indeed agents within the context of war, as they constantly work to ensure their own survival and that of their families and communities. Women also exercise agency as combatants.

White argues that military training often emphasizes the 'other-ness' of both the enemy and of women. Stories of women combatants are thus marginalized under the assumption that women are not active agents in war, but are merely victims of men's violence. Hypermasculine conceptions of soldiers often prevent women combatants from being recognized as equals. In many cases, sex workers' additional roles, such as spying, are understated while their sexual roles are overstated. Indeed, women in combat are often viewed as temporary exceptions to women's 'true' nature (2007).

Girl children also exercise agency and resistance during armed conflict. While children do not have the power to disobey their commanders outright, they are able to exercise some agency, and indeed children and youth have found some sense of empowerment in joining militarized groups (Baines, 2009). Denov and Gervais explore the agency exercised by girls formerly associated with the Revolutionary United Front (RUF) in Sierra Leone, highlighting girls' capacity for negotiation, agency, resourcefulness, resistance and mutual forms of support. They emphasize that ingenuity and creativity on the part of these girls was used strategically for survival and security. Specific strategies identified included using small arms, aligning oneself with a commander, perpetuating 
violence, and acts of both acquiescence and resistance. Girls also violently resisted sexual assault (Denov \& Gervais, 2007, p. 895).

In some cases, perpetuating acts of violence made girls more valuable within the ranks, which allowed them to become safer and gave them more privileges. Indeed, the girls Denov and Gervais interviewed associated guns with a sense of power and security (Ibid). White, too, found that women in leadership positions during war may find empowerment in the conflict, but noted that most testimonies of women indicate that partaking in violence was not key to this empowerment (2007).

I have discussed at length the ways in which violence against women in war is gendered, and the ways in which existing inequality works to further disadvantage women in war. However, Denov and Gervais found that girls were also able to use conventional gender roles to their own security advantage; one example was excelling at domestic chores in order to avoid participating in combat (2007). They note, "Although bush marriages may be perceived as a form of sexual slavery, they have also served as a site at which some girls reframe their victimization and, however minimally, transform it into a more secure space" (Ibid, p. 898). While I would argue that bush marriages are indeed a form of sexual slavery, I nonetheless find it important to note the ways in which women and girls are able to exercise resistance to their own victimization.

Finally, Denov and Gervais identified female solidarity as constituting a form of subtle resistance because the exchange of feelings and life stories was strictly forbidden in the RUF. This solidarity also helped girls to maintain their psychological and emotional well-being (Ibid). As will be discussed in Chapter 5, female solidarity was also described 
as a mode of resistance in the testimonies of Burmese women during the New York Tribunal (Nobel Women's Initiative and Women's League of Burma, 2010).

In reaching out to each other, women and girls have worked to preserve their own wellbeing in the face of atrocity and have refused to accept the isolation that the perpetrators of violence have tried to force upon them. Women's tribunals offer a particular opportunity for women to stand in solidarity with one another. I will now turn to an overview of the previous women's tribunals, held in Vienna and Tokyo, before moving forward in the discussion of the International Tribunal on Crimes Against Women in Burma. 


\section{Chapter 4: A Genealogy of Women's Tribunals}


Speaking these histories has an essentially redemptive purpose: to redeem that suffering in its telling and in the contribution of that truth to the production of a new moral order (Posel D. , 2008, p. 128).

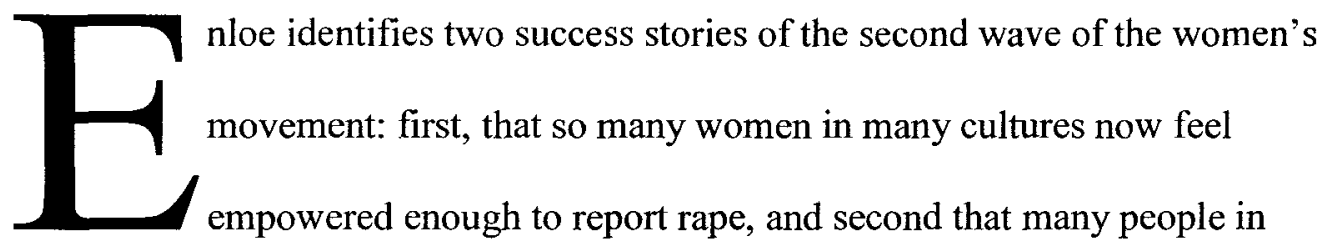
authority are now compelled to take sexual violations seriously (2000). In June 1996, eight men were charged with raping Bosnian Muslim women in an International War Crimes Tribunal. It was the first time that rape was treated separately as a crime of war. In Arusha, the International Criminal Tribunal for Rwanda handed down the first guilty verdict by an international court that included rape in the crime of genocide. Rape has also been expressly included as a war crime under the Rome Statue establishing the International Criminal Court (Ibid).

These advancements constitute significant progress and provide survivors of wartime sexual violence with opportunities to pursue justice. In some cases where the international community has been slow to act, however, civil society has stepped in to work for justice. In addition to the International Tribunal on Crimes Against Women of Burma, non-governmental women's organizations have organized two other popular tribunals in order to address violences perpetrated against women. This chapter provides a genealogy of the two previous women's tribunals - the Global Tribunal on Violations of Women's Human Rights (the Vienna Tribunal) and the Women's International Tribunal on Japanese Military Sexual Slavery (the Tokyo Tribunal). 


\section{THE GLOBAL TRIBUNAL ON VIOLATIONS OF WOMEN'S HUMAN RIGHTS, VIENNA}

The Global Tribunal on Violations of Women's Human Rights (the Vienna Tribunal) took place on June 15, 1993. The Tribunal was part of the non-governmental (NGO) parallel activities during the UN World Conference on Human Rights, the largestever human rights gathering (Rogers, 1994). The goal of the World Conference was to review and evaluate the effectiveness of the existing international human rights machinery. The Vienna Tribunal was scheduled for the second day of the World Conference in order to immediately call attention to women's human rights issues and to demand that delegates address these concerns throughout the Conference process.

The Vienna Tribunal was a key strategy of the Global Campaign for Women's Human Rights, a coalition of groups and individuals working around the world for the advancement of women's human rights. The Global Campaign viewed the World Conference as a natural site to highlight a transformative vision of human rights that would include women's rights. In the months leading up to Vienna, the regional movements within the Global Campaign worked for the application and implementation of such a human rights vision in their respective areas. These women were an active presence in the preparatory meetings for the Tribunal and strove to identify common themes that could be emphasized in Vienna (Bunch \& Reilly, 1994).

The organizers of the Vienna Tribunal determined seven objectives for the event. First, the Tribunal would demonstrate the obstacles to women's enjoyment of human rights stemming from the distinction between public and private spheres, especially regarding violence against women. Second, Vienna would expose often-ignored violations of 
female human rights in war and conflict situations. Third, the Tribunal would reassert that women's human rights are universal and indivisible, and would draw attention to the ways in which some claims to collective cultural and religious rights effectively impede the universality of women's human rights. Fourth, the Tribunal would illustrate the gender-specific dimensions of those international human rights violations that were already recognized. Fifth, Vienna would highlight the implications for women in the secondary status of social, economic and cultural rights in relation to political and civil rights. For example, even where political and civil rights are realized, women are often socially, culturally and economically marginalized. Sixth, the Tribunal would complement the goals of the World Conference through evaluation of the effectiveness of existing human rights instruments, procedures, agencies and bodies, including the effectiveness of human rights NGOs, in advocating for and protecting women's human rights. In particular, the Tribunal would evaluate the effectiveness of this machinery in regards to its implementation. Finally, the Vienna Tribunal would strive to show that violations of women's human rights occur around the globe, in both industrialized and "less developed" countries (Bunch \& Reilly, 1994, pp. 10-12).

Members of the International Coordinating Committee organized testifiers and support people in their respective regions. The testifiers at the Vienna Tribunal included 33 women from 25 countries. The Tribunal testimonies were organized into five interconnected thematic sessions: human rights abuse in the family, war crimes against women, violations of women's bodily integrity, socio-economic violations of women's human rights, and gender-based political persecution and discrimination. These themes and the cases included within them were selected in order to recognize the diversity of 
women's experiences across boundaries of all kinds. At the Tribunal's opening, organizer Charlotte Bunch reminded the audience that "behind each of these stories stand the lives of millions of women" (Rogers, 1994). Indeed, the testimonies also recalled the commonalities of women's experience across many boundaries - geography, age, class, race, religion and sexuality (Ibid).

The testimonies were delivered by the women themselves, or by their advocates. Support people accompanied testifiers to Vienna, and were available throughout the Tribunal process, including during preparation, and during and after the Tribunal. In the days before the Tribunal, testifiers attended an orientation session where they met their section moderators and each other. The moderators of the various sections were women from diverse regions who had been active in the Global Campaign (Bunch \& Reilly, 1994).

The panel of Vienna Tribunal judges worked in consultation with an advisory committee of women lawyers from Canada, Costa Rica, India and Egypt, and delivered individual responses throughout the Tribunal. The Judges also presented a final collective statement, delivered at the closing session (Ibid). This final statement called for the strengthening and reinforcing of the UN Convention on the Elimination of All Forms of Discrimination Against Women (CEDAW), for the establishment of an International Criminal Court for Women to protect and enforce women's human rights, and for the establishment of a UN Special Rapporteur with a broad mandate to investigate violations of women's human rights (Ibid, p. 85).

The Vienna Tribunal is widely recognized as a significant advocacy moment in the promotion of women's human rights. The organizers of the Vienna Tribunal were able to 
strategically shape the agenda and focus of the UN World Conference on Human Rights. Indeed, in addition to organizing NGO activities to take place during the World Conference, the women of the Global Campaign also took part in the preparation of the Conference itself. The women effectively pressed for the inclusion of text on women into the draft text that shaped the Conference agenda, which facilitated its later inclusion and passage in the final declaration at the Conference itself. The women of the Global Campaign also negotiated with the Conference Secretariat and secured time on the Conference agenda to present a report on the Vienna Tribunal. In doing so, they ensured that the Tribunal's recommendations would be officially recorded as part of the World Conference documentation (Bunch \& Reilly, 1994).

The Vienna Tribunal was quite successful in drawing international attention to a worldwide pattern of abuses of women's human rights. Bunch and Reilly write that the Global Tribunal "gave vivid expression to the life and death consequences of women's human rights violations. It provided graphic demonstration of how being female can be life threatening, subjecting some women to torture, terrorism and slavery daily" (Ibid, p. 8). Communications strategies were a key component of the Tribunal planning. When possible, testifiers were asked to submit a draft of their testimony, a brief biography and a photograph in advance so that organizers could better coordinate the Tribunal and prepare information packets for the media. Throughout the Tribunal and the rest of the UN World Conference, the Global Campaign distributed information electronically and through the media (Ibid). Bunch and Reilly articulate, "There are obstacles to getting the 'right' kind of media for women's concerns... Gaining access to the increasingly influential global media...without losing control of the message, is an even greater 
challenge" (Bunch \& Reilly, 1994, p. 97). The Vienna Tribunal received coverage in a number of major news outlets including the Washington Post, the New York Times and was featured on CNN. In order to be sure that the Tribunal's message was being disseminated, the Feminist International Radio Endeavour (FIRE) also broadcast throughout the process, including daily afternoon "Radio Tribunals" involving interviews with women who were unable to present their cases during the formal Tribunal but who still wanted their stories to be heard (Ibid).

In addition to garnering international attention, the Vienna Tribunal had real outcomes in the promotion of women's human rights in the international community. This is perhaps the most important achievement of the Tribunal, and is reflected in the creation of three new measures - the Vienna Declaration, the UN Declaration on the Elimination of Violence Against Women, and the appointment of a UN Special Rapporteur on Violence Against Women.

The final statement of the UN World Conference on Human Rights, known as the Vienna Declaration, devotes several pages to prioritizing women's human rights and equity, and calls on the UN and national governments to recognize the elimination of violence against women as a human rights concern. The Vienna Declaration was adopted by a consensus of 171 UN member states at the close of the conference, on June 26, 1993. Drawing directly on the work of the Global Campaign, it affirms other UN human rights instruments, including CEDAW and the Declaration on the Elimination of Violence Against Women. 
The impact of women can be seen throughout the Declaration. In addition to passages referring to women's rights throughout the text, there are nine paragraphs under the title "The equal status and human rights of women" (United Nations, 1993b). Most pertinent to our discussion looking forward to the New York Tribunal, in regards to conflict and war situations, the Vienna Declaration affirms that violations of women's human rights include murder, sexual slavery, forced pregnancy, and systemic rape, and that these violations require a "particularly effective response" (Ibid, Section II, paragraph 38). Indeed, the Declaration not only recognizes women's human rights as universal, but emphasizes that their promotion should be a top priority for the international community:

The human rights of women and of the girl-child are an inalienable, integral and indivisible part of universal human rights... The human rights of women should form an integral part of the United Nations human rights activities, including the promotion of all human rights instruments related to women (United Nations, 1993b, pp. Section I, paragraph 18).

The UN Declaration on the Elimination of Violence Against Women was already in the process of being drafted at the time of the Vienna Tribunal, but received additional impetus from both the Tribunal and the passage of the Vienna Declaration. It was rapidly adopted by the UN General Assembly in December 1993. In fact, the adoption of this Declaration was the first time that all UN member states agreed on a definition of violence against women (Bunch \& Reilly, 1994). Furthermore, Article 4(d) claims that states should ensure that women subjected to violence have "access to the mechanisms of justice and...to just and effective remedies for the harm they have suffered" (United Nations, 1993a). This Declaration thereby sets an important commitment for the 
international community to demand accountability and seek justice for violations of women's human rights.

In March 1994, the $50^{\text {th }}$ session of the UN Commission on Human Rights adopted a resolution including the three-year appointment of a Special Rapporteur on Violence Against Women, including its causes and consequences. The resolution requires that the Special Rapporteur report to the Commission on an annual basis (Bunch \& Reilly, 1994). The appointment of this Rapporteur was a direct demand of the final judges' statement at the close of the Vienna Tribunal. The position continues to this day.

Based on feedback from testifiers and attendees, Bunch and Reilly argue that the Vienna Tribunal was effective in three additional ways. First, it served to deepen the analysis of what constitutes women's human rights and fostered a greater consciousness of genderbased human rights abuses. Second, it was a powerful focal event, to which diverse women could point in support of their varying claims. It was also an empowering event for many who testified and for those who listened. Finally, the Vienna Tribunal became a symbol for long-neglected human rights abuses and for the growing demand for accountability (Ibid).

\section{THE WOMEN'S INTERNATIONAL TRIBUNAL ON JAPANESE MILITARY SEXUAL SLAVERY, TOKYO}

The Women's International Tribunal on Japanese Military Sexual Slavery (the Tokyo Tribunal), was convened December 8-12, 2000, in Tokyo. The Tokyo Tribunal was established to consider the criminal liability of high-ranking Japanese political and 
military officials, as well as the responsibility of the state of Japan, for the rape and sexual slavery systematically perpetrated throughout the Asia-Pacific region during the 1930s and 1940s. The Tokyo Tribunal built on the work of Vienna, noting in the preamble of its Charter the increased attention to violence against women that had arisen from the Vienna Declaration and the subsequent Beijing Platform from the 1995 Fourth World Conference on Women (McDonald, Argibay, Chinkin, \& Mutunga, 2001, p. A1).

The Tokyo Tribunal developed out of the work of various women's NGOs across Asia, particularly including the Japan-based organization Violence Against Women in War Network. Tribunal preparation was international, but remained primarily based in Asia. Indeed, an International Organizing Committee was formed to take on responsibility for research and the investigation of cases. This Committee was comprised of three groups organizations based in victimized countries, an organization based in Japan (the offending country), and an International Advisory Committee comprised of scholars and human rights activists. Prosecution teams from ten countries - North and South Korea, China, Japan, Indonesia, Malaysia, the Philippines, Taiwan, East Timor and the Netherlands - presented indictments (Chinkin C. M., 2001).

The Tokyo prosecutors argued that the trials that had taken place at the end of the Second World War regarding Japan's conduct in the war were incomplete because they had failed to adequately consider the rape and sexual slavery that had occurred, and had not brought charges for these crimes. Indeed, the Tokyo Tribunal judges began their final judgement by noting, "That a court, especially an internationally constituted court, would deliberately ignore a systematic atrocity of this dimension is unconscionable and 
profoundly discriminatory" (McDonald, Argibay, Chinkin, \& Mutunga, 2001, p. 1). The Tokyo Tribunal was thus envisioned as a continuation of previous trials.

Over 75 survivors of Japan's "comfort women" policy were present at the Tokyo Tribunal, with many providing evidence (Chinkin C. M., 2001). The judges also heard testimony from experts and from two Japanese military veterans (Violence Against Women in War Network - Japan). The Japanese government was invited to participate, but did not respond to the invitation. One major development of the Tokyo Tribunal in relation to previous prosecutions was the naming of Emperor Hirohito among those accused. Indeed, the evidence presented consistently linked both the Japanese state and the Emperor to the atrocities.

Unlike the Vienna Tribunal, the Tokyo process strictly adhered to legal procedural constraints, such as the separation of the judges and the prosecution, and the entering and recording of all evidence presented. Following the testimony, the judges' panel spent a day in deliberation, with assistance from a team of legal advisors. Together, they prepared a preliminary judgment, which was presented on the final day of the Tribunal. The final judgment, including fuller and more detailed legal analysis of more than 300 pages, was delivered at the Hague on December 4, 2001. The judges condemned the atrocities described by testifiers as sexual slavery. The judges found Emperor Hirohito guilty by reason of command responsibility; furthermore, they declared the state of Japan guilty of violating treaties and customary international law regarding slavery, forced labour, trafficking and rape (Chinkin C. M., 2001). 
The Tokyo Tribunal was established in concordance with the testifiers' belief that acknowledging and assigning responsibility for the crimes committed against them would grant them a sense of peace and greater security with which to live out the remainder of their lives. Indeed, the judges argued that the testimonies described the ways in which the denial of recognition and justice, as well as community rejection, exacerbated the suffering of survivors (McDonald, Argibay, Chinkin, \& Mutunga, 2001). Chinkin further emphasizes the importance of challenging the prevailing myths surrounding sexual offences (2004). In assigning responsibility for crimes away from the women who survived them, the Tokyo Tribunal can be seen as potentially contributing to the healing process of its testifiers, even without legal accountability (McDonald, Argibay, Chinkin, \& Mutunga, 2001).

It should be noted that, despite the findings of the Tokyo Tribunal and international pressure, to the present day, Japan continues to deny legal responsibility for the atrocities (Chinkin C. M., 2001). Even so, Chinkin argues that the Tokyo Tribunal illustrates a "striking example of the developing role of civil society as an international actor" (Ibid, p. 338). Indeed, the final judgement of the Tokyo Tribunal commends the courage of those who testified, and recognizes the inspiration they provided to many other survivors of the 'comfort women' policy to come forward and mobilize for the pursuit of justice. In bringing their stories forward, these testifiers undoubtedly paved the way for future efforts to demand accountability for these and other atrocities. The Tokyo judges write,

In an extraordinary way, the former 'comfort women' have contributed substantially to the emergence of a larger global movement to recognise and respect women's human rights, to end impunity for crimes of sexual and gender violence, and to repudiate the notion that sexual abuse of women 
is an inevitable consequence of war and conquest (McDonald, Argibay, Chinkin, \& Mutunga, 2001, p. 1).

Just as the Vienna Tribunal effectively illustrated a pattern of violations of women's human rights extending around the globe, so too the findings of the Tokyo Tribunal illustrate that rape in the 'comfort stations' was not an inevitable instrument or consequence of war, but that it instead formed part of the machinery considered necessary to the pursuit of Japan's military objectives on an international scale (Chinkin C. M., 2001). In this way, both Vienna and Tokyo look forward to a better understanding of the ways in which women are subjugated to and abused by official policy in conflict. This legacy is an important one as we turn our attention to the International Tribunal on Crimes Against Women of Burma. 


\section{Chapter 5: "This is My Witness" - The New York Tribunal}




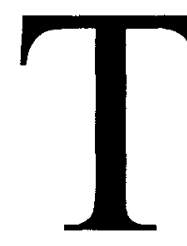

he International Tribunal on Crimes Against Women of Burma (the New York Tribunal) convened in early March 2010 in New York City, and was organized internationally by two non-governmental organizations - the

Nobel Women's Initiative and the Women's League of Burma. In summer 2009, organizers of the New York Tribunal held a meeting with women from Burma in Thailand, in order to establish objectives and expectations for the Tribunal, as well as to hear from the women of Burma how they wanted their Tribunal to be shaped. The women at the meeting discussed the models of the previous women's tribunals. They ultimately decided to form a hybrid tribunal, based mainly on the model of the 1993 Vienna Tribunal.

The more open format of the Vienna process allowed testifiers to tell their stories without having to satisfy strict legal requirements, minimizing the possibility of re-traumatization. The activists from Burma also emphasized that they want to distinguish the New York Tribunal from the mock trials continually taking place within Burma, such as the widely denounced trial of democratically-elected leader Aung San Suu Kyi in 2009 (Nobel Women's Initiative, 2009a). Hayner argues that criminal trials and truth commissions fill different roles and therefore cannot replace each other. At the same time, she argues that truth-telling processes have sometimes directly strengthened subsequent criminal prosecutions (2002). The New York Tribunal organizers wanted to be clear that the Tribunal is meant to complement and promote future International Criminal Court (ICC) prosecutions, not to replace or duplicate them. 
As mentioned previously, the day-long New York Tribunal was comprised of 12 testimonies delivered by women of Burma. Due to travel and security constraints, some testifiers appeared in person, while other testimonies were written in advance and read by trusted friends and supporters. All testifiers were accompanied by support persons throughout the entire Tribunal process. Similar to the past women's tribunals, testimonies were organized into categories in order to address a wide range of human rights violations. These categories served to underscore the systemic nature of human rights abuses in Burma. A panel of judges, including Nobel Laureates and international law experts, made closing remarks and recommendations linking the testimonies to international human rights and legal standards, and called on the Burmese regime, the international community and international civil society to take specific actions for justice in Burma. A Final Judges' Report and Tribunal film, to be widely distributed in the months following the New York Tribunal, were also produced by the organizers.

I attended the Tribunal in March 2010, and recorded all of the sessions of testimony, as well as the judges' findings and recommendations. As discussed in Chapter 1, I reviewed the transcript of the Tribunal testimony, as well as my observational notes, in order to identify themes which emerged, both within and across the three testimony sessions. In this chapter, I will examine the themes which emerged at the International Tribunal on Crimes Against Women of Burma. I will also highlight some of the judges' findings and recommendations. 


\section{THEMES FROM THE TESTIMONIES}

As noted earlier, the testimonies of the New York Tribunal were divided into three sessions, based on the category of violations discussed - sexual violence against women; civil and political violations; and social, economic and cultural violations. In each session, four women testified to abuses perpetrated against themselves, as well as against their families and communities. It should be noted that this chapter will not provide a comprehensive synopsis of each testimony. A summary of each testimony can be found in the official Tribunal Report (Nobel Women's Initiative and Women's League of Burma, 2010). The Tribunal can also be viewed in full on the archived webcast, the details of which can be found in Appendix I.

\section{SEXUAL VIOLENCE AGAINST WOMEN}

Three of the four women who were scheduled to testify in this session of testimony were unable to attend, due to last-minute visa difficulties. In order that their stories could still be brought to the world, trusted support persons and advocates read the absent women's testimony during the New York Tribunal.

Chang Chang and three of her friends were attacked and gang raped by a group of Burmese military soldiers. When news of the attack spread, she was punished for bringing shame to her family, school and community. Chang Chang was arrested by the police for 'defaming' the same soldiers who raped her, and served a prison sentence for charges of prostitution. 
Naw Ruth Tha was forced to work as a porter, carrying heavy loads for the Burmese military; she was five months pregnant at the time. Each night, despite the strenuous work days and her pregnancy, Naw Ruth Tha was repeatedly raped by the soldiers. When her father refused to allow the military to take her for a second term of portering, the soldiers shot and killed him, before burning down the entire village. "From that day," she said, "we all started running".

Ma Htu was uneducated and facing limited opportunities near the Burma-China border when a man promised her a job as a cook in China. Only when she had crossed into China without identifying documents did she find that the promised job was not available. Instead, Ma Htu and another woman were sold into arranged marriages, where they were locked up and beaten. When she finally escaped, the police provided no protection and turned Ma Htu over to the Burmese military, who charged and imprisoned her for being a trafficker. She was never granted legal assistance.

Lway Moe Kham was the oldest of seven siblings, and took over as head of the household when her father died and mother fell ill. She moved to a town on the ChinaBurma border to find better paying work, and was promised a restaurant job in China. She was taken across the border without identification, only to be held against her will by human traffickers, who tortured her into agreeing to an arranged marriage. Weakened by beatings and forcibly injected drugs, Lway Moe Kham managed to escape before the wedding, and was eventually rescued by a Burmese women's organization. 
Testimony Theme: Shame and Silence

One of the most prominent themes in this first session of testimony was the way in which the women of Burma who had suffered sexual violence were further subjected to what session moderator Lway Aye Nang called "tortures of shame" and "tortures of silence". The soldiers who raped Chang Chang and her friends threatened that they would kill her family if she told them what had happened. As she noted in her testimony, "Before and after they raped me, they threatened me. They said if I told anyone about this they would arrest me and kill me". As a result, Chang Chang was afraid to speak of being attacked for fear of brutal consequences, both for herself and for her family members. Naw Ruth Tha also spoke of how soldiers threatened to harm both her and her unborn baby if she did not remain quiet while they raped her.

This forced silence had severe consequences. Chang Chang poignantly explained the torture of silence: "I was so scared, but nobody stood for me. Nobody spoke for me". Naw Ruth Tha described the shame and silence suffered by women who were subjected to sexual violence as forced labourers:

Some young women from our village who had been raped by Burma Army soldiers got pregnant. Some felt so shameful that they did not show their face in the village. There were quite a few women who hung themselves. If the women ran away the soldiers shot after them and killed them. No one dared to run away anymore. There were many women who lost their lives in this way. And no one knew where they went or what happened to them... Every single woman stayed quiet and kept the military's secret about what happened to them. Even though they didn't talk about it, I could tell that other women were also raped, like I was, because I heard other women were screaming at night, like I had screamed when I begged the soldiers to stop.

The testifiers described shame and silence within their families and communities.

Initially, Chang Chang's family blamed her for her rape because she was outside at night. 
She explained, "I was very ashamed to talk about this experience with my family. This is not something girls in our village would tell their parents about because it is very shameful...I was also worried that my family would feel ashamed in our community". Naw Ruth Tha did not tell her mother what had happened to her while working for the military because she did not want her mother to "anguish". She said that she suspected that her mother had suffered similar violations in her time as a porter and that her mother had not told her about it for the same reason. Chang Chang and her friends were arrested and shamed in their community after the story of their rape was spread to the media. Chang Chang testified, "From the police station to the hospital we had to walk through our community with footcuffs and handcuffs. Many people were looking at us along the way...We were so embarrassed. We cried a lot".

\section{Testimony Theme: Impunity for Sexual Crimes}

Another common thread among the testimonies in the first session of testimony was the prevalence of impunity for perpetrators of sexual crimes. In the case of each testifier, justice has yet to be served. Not only were none of the soldiers who raped Chang Chang and her friends prosecuted for their crimes, the girls themselves were interrogated repeatedly by the military, and eventually were sentenced to one year in prison for prostitution. As Chang Chang explained, the soldiers who raped them then accused them of "defaming the country". Naw Ruth Tha never saw justice for the many violations perpetrated against her and her family, and was forced to flee her village. Ma Htu was not given any legal assistance whatsoever when she was charged with human 
trafficking, and was punished in place of her captors. While Lway Moe Kham managed to escape, her traffickers also escaped prosecution and punishment.

\section{Testimony Theme: Lack of Supports for Survivors}

The four testifiers in the session on sexual violence against women repeatedly pointed to the lack of supports available to women survivors of these crimes. While not surprising, it should be noted that the military does not provide such support. Naw Ruth Tha explained that many people were injured when they were working as porters for the military, but that no medical help was available to them. People were thus forced to try to treat their injuries themselves. Naw Ruth Tha's pregnancy was also not taken into account by the soldiers. She noted, "The military troops did not even care that I was pregnant. Even though I was pregnant, they still forced me to carry the heavy loads like anyone else". Rather than providing protection for Ma Htu as a survivor of human trafficking, the police in China, as well as the Burmese authorities, treated her as a criminal.

The testifiers also identified a lack of supports within their communities. Chang Chang's story provided many examples of this. Chang Chang said that the only women's organization available in her community was run by the wives of the military, so victims of military rape could not go to them for support. In fact, after Chang Chang's story was broadcast by the media, this organization took her first to the local regime office and then to the military camp, where she was interrogated. When Chang Chang and her friends were taken by the military for a forced "medical examination", the doctors sexually 
assaulted the rape victims. After that, the girls were always afraid to go to the hospital, a fear that could have dire health consequences for survivors of sexual violence.

Although they were in their teens at the time, these girls also received no support from their school community. After their story was reported by BBC Burmese, Chang Chang and her friends were caned in front of their entire school, and expelled for "tarnishing the reputation of the school". While she was unsure as to whether or not the principal of the school had connections to the military, Chang Chang reported, "No one at the school tried to protect us". Naw Ruth Tha argued, "The community doesn't support women who are raped because nobody talks about it; it is too shameful and too dangerous to talk".

\section{CIVIL AND POLITICAL VIOLATIONS}

The four testifiers in the second session of testimony brought stories of civil and political human rights violations in Burma. These violations ranged from arbitrary arrest and detention, to torture during detention and other persecution.

Saw Myat Mar was an active member of the Generation '88 pro-democracy protestors and former colleague of Aung San Suu Kyi. Both she and her husband were persecuted and arrested by the regime when they spoke out against the military's violence against civilians. While in prison, Saw Myat Mar faced a variety of sexual violations. Following their release, both she and her husband were continually harassed and interrogated by the police and were threatened with arrest. Eventually, they were forced to leave Burma.

Nengpi lived with her husband, a village leader, in a community with a significant military presence. When a soldier stationed nearby deserted from his battalion, Nengpi's 
husband and a group of other men were accused of cooperating with the deserter. They were taken to the forest and brutally tortured. The soldiers arrested Nengpi and took her to where her husband lay dying and tortured her in an attempt to make her confess to sleeping with the deserter. When she refused, she was sentenced to over a year in prison.

Daw Khin San Nwe was arrested for activities with the Generation ' 88 pro-democracy protests. She was five months pregnant when she was imprisoned and was forced to give birth in prison, without any medical assistance. As a result of the unsanitary conditions in the prison, as well as being beaten and starved, she continues to suffer a number of medical complications. When she returned to pro-democracy activism following her release from prison, Daw Khin San Nwe was again detained and was denied all outside communication.

Daw Nyunt Nyunt worked with Aung San Suu Kyi and the National League for Democracy. She was with Aung San Suu Kyi at the Depayin Massacre in 2003, when soldiers (some of whom were dressed as monks) attacked civilians supporting Suu Kyi. Daw Nyunt Nyunt was among those attacked. As a witness, she estimated that 70-80 people were killed that night; official regime reports claim that there were only four fatalities.

Testimony Theme: Lack of Justice and Persecution of Political Dissidents

The four testifiers in the testimony session on civil and political violations demonstrated clearly that the persecution of political dissidents and the absence of justice are widespread in Burma. Indeed, session moderator Thin Thin Aung noted that even the 
judiciary in Burma are part of the military regime. She reminded the audience that the four women who testified in this session of testimony represent thousands of people who have been rounded up by the regime, often for being in the wrong place, or with the wrong person, in the eyes of the military junta.

Saw Myat Mar was first sentenced to up to three years of hard labour. Her crime: distributing pamphlets informing people that a planned protest had been cancelled due to the threat of military violence. After she protested being made to carry a pot full of human feces, she was put into solitary confinement in a cell with rats and cockroaches and without light. Even after her release from prison, Saw Myat Mar was continually harassed by police. Eventually, she was forced to leave the country.

Daw Nyunt Nyunt witnessed the murder of dozens of pro-democracy supporters at the hands of the military. She described how soldiers tried to take off her clothes as they beat her: "My whole body was so bloody that my clothes stuck. They couldn't get my clothes off. They got my clothes off after dragging me 20 yards". Daw Nyunt Nyunt also saw many students who were killed and beaten. "The blood was coming out of their heads it was like water coming out of a pipe," she said. Daw Nyunt Nyunt was herself knocked unconscious by military personnel. She continues to suffer pulsating pain and compromised hearing from the head injuries she received in the crackdown.

Neither Nengpi nor Daw Khin San Nwe was ever granted access to a lawyer or any form of legal assistance. When a representative from a human rights organization came to visit the prison where she was detained, Daw Khin San Nwe and the other political prisoners 
were hidden from view. Following the Depayin Massacre, no investigations were done. Instead, the regime blamed Aung San Suu Kyi and the opposition for the event.

\section{Testimony Theme: Sexualized Torture}

The theoretical discussion in Chapter 3 noted that violence against women in armed conflict often targets women as women. The testifiers in the second session of testimony also spoke of torture which was distinctly designed to degrade, humiliate and terrify women. Nengpi said that there were many people who died or whose lives were ruined by torture. Saw Myat Mar described the conditions in the prison where she was held: "Like other prisoners, I was not allowed to eat, drink, sleep, or bathe. I was also purposely kept in unsanitary conditions. This kind of treatment poses serious health problems and causes psychological damage, especially to female political prisoners having their periods". Daw Khin San Nwe confirmed, "Especially as women, it was very unsanitary".

Both women also spoke of the terrible conditions faced by pregnant prisoners. Saw Myat Mar testified that midwives were ordered by wardens to perform abortions on prisoners. It should be noted that abortion is almost entirely illegal in Burma and the procedures are not done outside prison. Though Daw Khin San Nwe was five months pregnant when she was first imprisoned, she was forced to sit on a small chair for long hours of interrogation. When it came time to have her baby in prison, Daw Khin San Nwe was required to pay for medical assistance. As she could not pay, prisoners who were physicians offered to help, but the warden would not allow it. Daw Khin San Nwe was left to deliver her baby alone. In her weakened state, her uterus collapsed during labour, 
and she was unable to have any more children. Daw Khin San Nwe was worried for the future of her son, and so she gave him up to relatives outside the prison.

The testifiers also bore witness to sexual violence and harassment faced by female prisoners, particularly political prisoners. Daw Khin San Nwe said that it was very common for women political prisoners to be charged as prostitutes. During her time in prison, the guards repeatedly interrogated Saw Myat Mar. During one interrogation at least eight men approached her; they were naked. When she begged them not to touch her, they laughed. Saw Myat Mar also described women being forced to have invasive medical examinations:

That day the warden called us one by one. Each woman had to go separately. When she would come back she was not allowed to talk with the rest of us who were still waiting for our turn. When it was my turn, I went inside the room, there was only one women doctor $(O G)$, and there were other people in the room: men who were just watching me. The doctor told me to lie down on the bed and then started examining my vagina. I asked why they were doing this. I was told that there was a pregnant prisoner and they need to check to make sure it wasn't me because the pregnancy was a result of a rape by a guard. One of the men was taking video of the examination... They used this check up to break the women political prisoners' spirit of fighting for human rights and human justice.

\section{SOCIAL, ECONOMIC AND CULTURAL VIOLATIONS}

The final group of four testifiers told their stories of social, economic and cultural human rights violations. These violations included forced relocation, forced labour, and displacement within and outside Burma. 
Esther's village was forcefully relocated by the Burmese military. Soldiers ordered the villagers to destroy their own homes, church and cemetery to make way for a military dam project. When the soldiers brought the villagers to their new location, the villagers found they were unable to grow food on the new land and faced starvation. Though Esther and her family had gone to a different location on their own, they too lacked sufficient food and clean drinking water. Three people died in the first week after being relocated.

Naw Muhsit and her family were continually forced to move because of repeated attacks by the military regime. On her ninth birthday, Naw Muhsit left Burma for the last time. Her sister came close to death on the journey. After fleeing their village, Naw Muhsit's family lived in refugee camps along the Thailand-Burma border. They stayed there for ten years before finally immigrating to Canada.

$\mathrm{Ma} \mathrm{Pu}$ Sein was forced to labour on roads for the Burmese military government. If she stopped to rest, soldiers would beat her. Working with Ma Pu Sein were children as young as ten years old. The labourers were given little or no food, water, or shelter, and the ill and injured were not given medicine. When Ma Pu Sein became ill, her ten-yearold was forced to take her place as a labourer. Many women labourers were raped at night by the soldiers. Those who tried to escape were hunted down. After four years of forced labour, $\mathrm{Ma} \mathrm{Pu}$ Sein fled Burma, forced to leave her children behind. She has since been reunited with her two daughters, but has lost contact with her son. She fears for his safety. 
Naw Thaun Nyunt suffered a variety of abuses at the hands of the Burmese military regime. Soldiers destroyed her family's farming livelihood when they confiscated all the family's property and killed and ate their animals. Naw Thaun Nyunt's father was shot by soldiers, and her mother was killed by a landmine the soldiers laid at their door. Naw Thaun Nyunt herself was shot in the leg by soldiers at age 12. Finally, the military burnt down Naw Thaun Nyunt's entire village, which was comprised of 100 households.

\section{Testimony Theme: Loss of Home}

One clear theme in the testimonies in this third session was the loss of home experienced by the testifiers. Esther saw her entire community destroyed, and was then forced to relocate far from her home. She described her loss: "In my old village, all my siblings were born. All my siblings grew up there...We also had our plantations, which gave us life... That is why we have such sentiments toward the old village". While Naw Muhsit and her family moved back and forth over the Thai-Burma border many times, she told the Tribunal audience, "We always preferred to be in Burma. because it was where we felt was home". She also noted, "In Thailand, we were illegal, and we felt like strangers in someone else's country". Ma Pu Sein and Naw Muhsit contended that the killing and forced relocation of ethnic minority peoples also resulted in the loss of cultural heritage.

The testifiers also described ways in which this loss of home was forced upon them repeatedly by the military regime. Esther testified that villages were sometimes destroyed again after they had been rebuilt. Naw Thaun Nyunt testified that she had lost track of the number of times she had had to pick up and run from military attacks. As a 
forced labourer, Ma Pu Sein was forced to leave her home for years at a time. She noted that the only way to be able to return home was to pay the soldiers or to sign a statement committing to returning to labour. Those who did not return on time were punished.

\section{Testimony Theme: Systemic Exploitation of Women}

Another theme that emerged in the third session of Tribunal testimony was the systemic exploitation of the women and people of Burma. Esther's village was destroyed so that the military regime could complete a dam project. All of the profits of such projects remain in the hands of the junta. The villagers were given only minimal compensation. Esther testified that her family received the equivalent of \$50 USD for their home, only a fraction of the worth of their property. The money Esther's family received for their farmland was equivalent to about three bags of rice or a small bamboo hut.

Naw Thaun Nyunt testified that when the military comes to a village, they take everything of value and sell it for their own profit. Naw Muhsit described how soldiers would place landmines on the farms of villagers to encourage them to leave and not return. The troops also set up military bases in abandoned villages. Ma Pu Sein testified that many women labourers were raped by soldiers after long days of work or when the women went into the jungle to take care of their personal hygiene. Women were also forced into 'marriages' with these soldiers. In all of these ways, the testimony pointed to the exploitation of the civilian population at the hands of the Burmese military regime. 


\section{Testimony Theme: Cross-generational Impact of Violations}

Finally, the testimonies in the Tribunal session on social, economic and cultural violations illustrated that the military's violence and oppression of the people of Burma is having a significant cross-generational impact. The people in Esther's village not only lost their homes, but also their livelihoods. In the new location, people were unable to farm due to a lack of water and proper fertilizer. She estimated that it would take them 50 years to make up for what they lost. This exploitation has clear implications for future generations.

$\mathrm{Ma} \mathrm{Pu}$ Sein saw children as young as ten years old being forced into labour by the Burmese military. When she became ill, her own child was forced to take her place as a labourer. Ma Pu Sein had to leave some of her children inside Burma when she fled. Naw Thaun Nyunt noted, "From 12 years old, I have been running from the Burmese military oppression". These violations against young children will undoubtedly have consequences across generations.

Naw Muhsit is a refugee, who is also a child of refugees. Displacement across generations is a serious concern for the future of Burma. Naw Muhsit noted that a lack of education among refugees limits future opportunities and encourages them to marry when they are young. She commented, "I am deeply concerned for the next generation of refugees. I wonder how they will tell their stories". Session moderator Hseng Noung Lintner echoed the concern that forced relocation over many generations will have severe impacts on the future development of the country. 


\section{THEMES ACROSS TESTIMONIES}

We have noted above the themes which emerged from each session of testimony at the International Tribunal on Crimes Against Women of Burma. It is also important to highlight the themes which emerged across all three sessions of testimony. These are the identification of government officials as the perpetrators of human rights violations, the widespread existence of human insecurity, the ways in which the women of Burma stand in solidarity with one another, and the desire of the testifiers for international action towards justice for Burma.

\section{Testimony Theme: Government as Perpetrators}

In virtually every testimony at the New York Tribunal, Burmese military and government officials were implicated as the perpetrators of human rights violations against the women and people of Burma. Chang Chang clearly stated that she and her friends were attacked and raped by at least seven Burmese military soldiers. "Everyone in our village knows who are the police and who are the soldiers. And then they took us to the military base. Even though some of the men did not wear uniforms that night, later we found out that they were all from the Burma Army", she testified.

Naw Ruth Tha said that many troops came through her village, regularly forcing civilians to work as porters. These same troops also killed her father and destroyed her village. $\mathrm{Ma} \mathrm{Pu}$ Sein and her children were forced to work for Burmese military personnel. The people of Esther's village were forcibly removed from their homes by the military, in order to make room for a government development project. Daw Nyunt Nyunt testified to the brutal military crackdown on a civilian pro-democracy gathering, which killed 
dozens of people. Naw Muhsit's family were forced to relocate several times as the result of repeated military attacks. Naw Thaun Nyunt, too, has spent her life running from the Burmese military.

The testimonies of the women also reflected the failure of the Burmese government to work for justice for the women of Burma. Ma Htu was imprisoned by the Burmese military after surviving human trafficking. Lway Moe Kham was trafficked to China because border guards took bribes rather than protecting women. Saw Myat Mar, Nengpi, and Daw Khin San Nwe suffered arbitrary arrest and detention, sexualized torture and continued harassment, all at the hands of Burmese government officials. As discussed in Chapter 3, and echoed by the Vienna and Tokyo Tribunals, the testifiers in New York pointed to the deliberate government decisions behind the crimes committed against them.

\section{Testimony Theme: Human Insecurity}

I examined in Chapter 3 the ways in which women conceptualize notions of security, wherein ideas of peace and security are not only focused on the absence of armed conflict, but also recognize that the fulfilment of basic needs is a key component of true security. Indeed, women often cite the fulfilment of basic needs as necessary to the building of sustainable peace. This theme also emerged in the testimonies of the New York Tribunal. The women who testified at the New York Tribunal noted the human insecurity that made them more vulnerable to, and resulted from, the human rights violations they suffered. 
While her testimony was in the first session of testimony, on sexual violence against women, Chang Chang described how families in her community were forced to work for the military on a regular basis ("at least twice a week"), taking away from their own farming and subsistence efforts. She also described how the military killed and ate a number of her family's cows, without permission and without offering compensation. Like Chang Chang, Naw Ruth Tha's testimony spoke not only of sexual violence, but also of ongoing forced labour practices.

Naw Ruth Tha described the vulnerability of her community, "In my village, there were only about 20 households. Villagers depended on raising animals and farming for their survival. Children had to attend school in town, which is very far away... When there is fighting, we have to run and hide in the forest". Nengpi described soldiers eating the villagers' food in her community. Naw Muhsit also expressed a constant vulnerability to military oppression and attacks:

This became our family's reality. As the Burmese troops moved east, they killed villagers, and burned their villages. The attacks happened during any season but it was especially difficult to flee during the rainy season, because of the muddy conditions which made it very difficult to walk and have food. At harvest time, the troops came into our villages and destroyed all of the food, leaving everyone to starve.

These economic difficulties also made the women more vulnerable to other rights abuses. Ma Htu's family struggled to support themselves. When her parents died when she was young, she went to live with her grandparents. Their financial situation meant that Ma Htu could no longer attend school. She was eventually trafficked into China. Lway Moe Kham was also made vulnerable to trafficking due to the dire economic situation of her family. 
The military's attacks on the civilian population have other impacts on human security as well. In addition to losing their livelihoods and lacking sufficient food and water, many people from Esther's village got sick from drinking the dirty stream water in their new location. Naw Muhsit testified that constantly living in transit meant that her family had no access to services such as medical care. Such insecurities pose serious threats to the healthful development of communities.

Chang Chang told the Tribunal audience, "What I want the world to know is - we are imprisoned in our own country. I want the world to know this". Naw Thaun Nyunt emphasized that military attacks on villages were regularly surprise attacks. Villages thus lived in a constant state of fear and uncertainty. Nengpi, too, noted that in militaryoccupied villages such as hers, the people live in constant fear. She described how her village "fractured" in trying to run from the soldiers: "We lost our hope and our belief in ourselves", she said. The constant threat of military oppression clearly has severe consequences for communities. The testimonies of the New York Tribunal illustrate that living in a continual state of fear means that the people of Burma cannot achieve sustainable peace and security.

This insecurity is also not contained within Burma's borders, but followed the testifiers after they managed to leave the country. The refugee camps where Naw Muhsit and her family lived for ten years were vulnerable to both military attacks and natural disasters. Naw Ruth Tha also spoke about insecurities in living in a refugee camp in Thailand. As refugees in Thailand, Naw Muhsit and her family were treated as second class citizens. At one point, Thai authorities forced them to destroy their own houses to support the 
image that Thailand was moving them somewhere safer. Daw Nyunt Nyunt pointed out that if the international community continues to let the Burmese regime act as it wishes, lawless countries will pop up around the world.

\section{Testimony Theme: Women in Solidarity}

In light of my feminist focus on recognizing women's resilience and agency, it is important to note that throughout the 12 Tribunal testimonies, the women of Burma expressed solidarity with each other. In opening the Tribunal, moderator Charlotte Bunch reminded the audience and the judges that each of the testifiers represented thousands of others in Burma. This was also reflected by the testifiers themselves. Chang Chang emphasized that she wanted the judges to know that there were many women and girls suffering in the same ways that she has suffered. Naw Ruth Tha noted that many women, both single and married were subjected to rape and sexual violence while portering and said, "I could hear other women crying just like me". Both Naw Muhsit and Ma Pu Sein took the opportunity that the Tribunal afforded them to also relate the stories of some of their friends and neighbours who had suffered abuses at the hands of the military.

The testifiers also highlighted ways in which they stood in resistance to their victimization by the military regime, including speaking out about what happened to them. As Naw Ruth Tha said, "I decided to testify because I believe that sharing my story can help protect other girls and women from what I have suffered". Daw Khin San Nwe described a women's resistance movement inside prison walls. Prisoners were provided with very little water, which had to be used for both drinking and bathing. This 
was an attempt to keep the women prisoners extremely dirty. In resistance, the women prisoners made special efforts to keep themselves as clean as possible.

After being forced by prison guards into having invasive vaginal exams, Saw Myat Mar and the other women prisoners tried to prevent the same thing from happening to the teenage girls in the same prison. They tried to pull the girls away from the prison wardens, but their resistance was met with heavy beatings. Saw Myat Mar was beaten unconscious and woke up in solitary confinement. Saw Myat Mar also described another example of women joining together in resistance while in prison:

One night, we were kicked out of the medical center by drunken guards who tried to harass a pregnant woman. I saw the guards look at her vagina and put their fingers in her. In response, some of the other prisoners and I went into the medical center and fought against the guards. We threatened to tell the high officer what we had witnessed. The guards begged us not to tell on them. After that night, the guards did not violate pregnant women anymore.

The testifiers further expressed solidarity with other women after surviving human rights violations. Naw Ruth Tha reflected, "I have gained strengths from women I trust, in my community and other safe places. They always encourage me and give me counselling... When I meet women who understand me and encourage me I feel more relief". Lway Moe Kham was rescued from human trafficking in China by a Palaung women's organization, of which she is now a part. She noted, "When I met the two women that came to help me at the Burmese home, I felt that they were giving me back my life". Naw Muhsit said that as a Karen woman, she has a responsibility to work for justice for the Karen people. 
The solidarity among the testifiers was obvious during the Tribunal as well. Each testifier had a support person who came up on the stage with her, and who came and stood beside her when giving testimony became especially difficult. More than once, after a testifier returned to her seat, she was embraced and encouraged by her sisters. In this way, the women stood in solidarity with one another in resistance to the oppression thrust upon them by the Burmese military regime.

\section{Testimony Theme: Women Want Action}

Finally, across all three sessions of testimony, it was clear that the women of Burma want their stories to prompt action. Saw Myat Mar noted, "I'm not a born politician. I became a politician because I see injustice everywhere in Burma and I want to help in bringing freedom to our country". The other Tribunal testifiers echoed this call for justice for the women and people of Burma.

The very first Tribunal testifier, Chang Chang, concluded her testimony by calling for punishment for the soldiers who perpetrated the crimes against her, and for the world to boycott the military regime and take action for justice in Burma. Naw Ruth Tha called on the international community to guarantee the safety of women and girls and to punish the Burmese regime. Esther urged the international community to pressure the Burmese regime to stop the practice of forced relocation. She also called for the junta to be ousted from power. Nengpi, too, called on the world community, particularly including China and India, to push for justice. Naw Muhsit said that if the Burmese regime does not act to protect its people, then the international community must intervene. 
The women also noted actions needed beyond the prosecution of perpetrators. Lway Moe Kham called for justice and action to protect the women of Burma. She also called for support to stop human trafficking, including supports for the education of women.

"We need to have education and jobs so we can support ourselves, and our families. And we want to say we know what our rights are even if they are denied to many of our women", she emphasized. Daw Khin San Nwe called for the international community to support the Burmese democracy movement. Naw Ruth Tha called on audience members to tell her story to other to increase awareness of what is happening in Burma.

In spite of all they have endured, the testifiers still expressed hope for change in their country. Chang Chang reflected that she foresees a bright future for Burma. Naw Thaun Nyunt, too, looked to the future, and dreamed of a peaceful Burma. In all of these ways, the testifiers at the International Tribunal on Crimes Against Women of Burma advocated for action towards justice for Burma. We will now turn to an overview of the Tribunal judges' findings and recommendations, which also focus on promoting action for justice.

\section{THE JUDGES' FINDINGS AND RECOMMENDATIONS}

In her testimony, Naw Muhsit reflected, "I share with you a common story that in its commonness has, in time, become normal". However, Naw Muhsit emphasized that while the stories of the testifiers are all too common in Burma, they must not be thought of as normal or acceptable. The Tribunal judges - Shirin Ebadi, Vitit Muntarbhorn, Heisoo Shin and Jody Williams - also made clear from their findings that the ongoing 
persecution and violation of the rights of the people of Burma is neither acceptable nor legal.

The judges noted that the Tribunal highlighted "the crimes and violations committed against women as part of the larger attack on democracy and the human rights, peace and security of civilian populations in Burma". They also pointed out that the testimonies illustrated a longstanding and ongoing tradition of impunity for perpetrators, particularly for perpetrators of gender-based violations. The judges further emphasized that women must be empowered to participate fully in the building of peace and legitimate democracy in Burma.

Based on treaty and declared obligations of Burma, as well as on customary international law, the judges found the Burmese military regime responsible, both individually and as a state, for the crimes and human rights violations recounted by the testifiers. They noted that Burma is also responsible due to its failure to act for justice or to prevent these violations through the investigation, prosecution and punishment of perpetrators, as well as its failure to protect and provide reparations to the victims of these crimes.

The judges of the International Tribunal on Crimes Against Women of Burma found that the actions of the Burmese military regime amount to "war crimes, crimes against humanity, crimes subject to universal jurisdiction, the failure of the regime to exercise its Responsibility to Protect and human rights violations". Under the Geneva Conventions and the Rome Statute which created the International Criminal Court, attacks against civilian populations - including the cases of sexual violence, forced labour, torture, forced displacement, and the destruction and pillage of property identified by the 
testifiers - amount to war crimes. Similarly, crimes against humanity refer to specific crimes committed as part of a widespread or systematic attack against a civilian population, such as the ongoing Burmese military attacks against civilians across Burma. The judges noted, "The fact that similar crimes have been committed against Burmese women in different parts of the country is evidence that the regime has a policy to actively commit and/or passively permit these attacks".

The judges also explained that under international human rights law, Burma has an obligation to protect all of its people, and to ensure that their human rights are both respected and protected. They further pointed out that in addition to violations of customary human rights law, the Tribunal testimonies pointed to violations of human rights treaties to which Burma is a party, including the Convention on the Elimination of All Forms of Discrimination Against Women, the Convention on the Rights of the Child, and the International Labour Organization Forced Labour Convention.

In light of these findings, and in order to promote action towards justice for Burma, the Tribunal judges made a large number of recommendations. These recommendations fell into four categories: recommendations to Burma's military regime; recommendations to the Asia-Pacific region, including the Association of Southeast Asian Nations (ASEAN) and bilateral and other channels; recommendations to the international community, particularly the United Nations; and recommendations to civil society. Given the large number of recommendations, I will list only the major recommendations here. The entire list of recommendations can be found in the official Tribunal report (Nobel Women's Initiative and Women's League of Burma, 2010, pp. 20-21). 
Recommendations to Burma's military regime:

- Stop all forms of violence against women. End the harassment, intimidation, arbitrary arrest, unlawful detention, torture and degrading treatment against women. Respect and adhere to the principles and norms of international criminal and human rights standards, particularly the Convention on the Elimination of All Forms of Discrimination Against Women.

- Stop attacks and persecution against ethnic nationalities and groups. Release immediately and unconditionally all political prisoners.

- Grant access to United Nations agencies and non-governmental humanitarian groups to ensure that women, in particular, are assisted effectively.

- Abide by rules of customary international law, such as the prohibitions against torture, slavery and violence against women and children.

- Establish an effective process for dialogue between different stakeholders including democracy groups, ethnic minorities and nationalities, and concerned authorities with emphasis on women's participation in the pursuit of democracy.

- Establish effective judicial mechanisms and other processes to establish accountability and provide adequate remedies for international crimes and human rights violations to end impunity.

Recommendations to the Asia-Pacific region:

- Call upon ASEAN through its Summit of Heads of Government to impel Burma to apply effective and time-limited measures to comply with the ASEAN Charter and international legal obligations and human rights standards.

- Call upon the various partners of ASEAN and other regional bodies and states engaging with Burma to influence constructive changes in the country.

- Prohibit trade with Burma involving goods produced through forced labour, as well as oil, gas and electricity generated as a result of forced relocations.

- Take effective cross-border measures to prevent and punish human trafficking, in particular that of women and children, and to offer gender and child sensitive measures to protect and assist those victimized by trafficking.

- Respect the rights of refugees and internally displaced persons, protect them from violence, abuse, exploitation and forced repatriation....and ensure the application of basic standards of international law.

Recommendations to the international community:

- Urge States to take collective action to ensure the implementation of Security Council resolutions $1325,1820,1888$ and 1889, which guarantee women's full participation in post-conflict reconstruction and freedom from all forms of sexual violence. 
- Strongly urge the UN Security Council to refer Burma to the International Criminal Court. (It should be noted that when this recommendation was announced, the testifiers burst into spontaneous applause).

- Call upon United Nations member States to fulfill their obligations to exercise universal jurisdiction and to prosecute through their national tribunals perpetrators of the crimes against the civilian population of Burma, including women.

- Urge the United Nations system to take measures to ensure that the Burmese authorities comply with international human rights standards and international humanitarian law.

Recommendations to civil society:

- Continue to engage with the people of Burma in and outside of the country to mobilize public pressure at the international, regional and national and local levels by raising awareness of the crimes and violations being committed by the Burmese military regime against the peoples of Burma, especially women and children.

- Demand that their governments and the relevant organs of the United Nations, including the Security Council, take action to implement the recommendations of this Tribunal - and others - to ensure the transition of Burma to genuine democracy and to ensure human rights, peace and sustainable human- and women-centred development.

On behalf of the Tribunal judges, Jody Williams noted, "We hope this Tribunal will amplify your cries, the cries of thousands of people, for justice". The International Tribunal on Crimes Against Women of Burma undoubtedly provided an important opportunity for the women of Burma to tell their stories to the world. It also served to articulate the many ways in which the Burmese regime continues to act illegally in regard to the civilian population of Burma. As the women themselves indicated, however, it is crucial that awareness should be accompanied by action. With this thought in mind, we turn now to the outcomes of the New York Tribunal. 


\section{Chapter 6: Amplifying Women's Voices - The Outcomes of the New York Tribunal}


$\mathrm{n}$ this chapter, we turn to the impact and outcomes of the International Tribunal on
Crimes Against Women of Burma. As indicated earlier, given that people's
tribunals are not legally enforceable, their effectiveness may be measured most accurately by not only accounting for their outcomes in the international (governmental) community, but also their outcomes in international civil society. This chapter will therefore explore both the political and civil society outputs and outcomes of the New York Tribunal. I will begin with a discussion of how the New York Tribunal was disseminated in the media. The diagram on the following page, introduced in Chapter 1, provides an outline of the outputs and outcomes to be explored in this chapter.

\section{MEDIA OUTPUTS AND OUTCOMES}

One of the major objectives of the New York Tribunal was to raise international visibility and awareness of crimes against women of Burma. Over 1000 people attended the Tribunal, either live in New York or via an online webcast (Nobel Women's Initiative, 2010a). While this audience count is in itself an achievement, in exploring the outcomes and impact of the Tribunal, it is essential to also examine how the Tribunal was spread to the broader public. This section will specifically speak to the presence of information regarding the Tribunal in news media.

I have documented 62 print news articles, as well as three radio broadcasts referencing the New York Tribunal. These news stories come from sources which span across the globe. A full 20 of the articles were printed in news sources which are internationally 


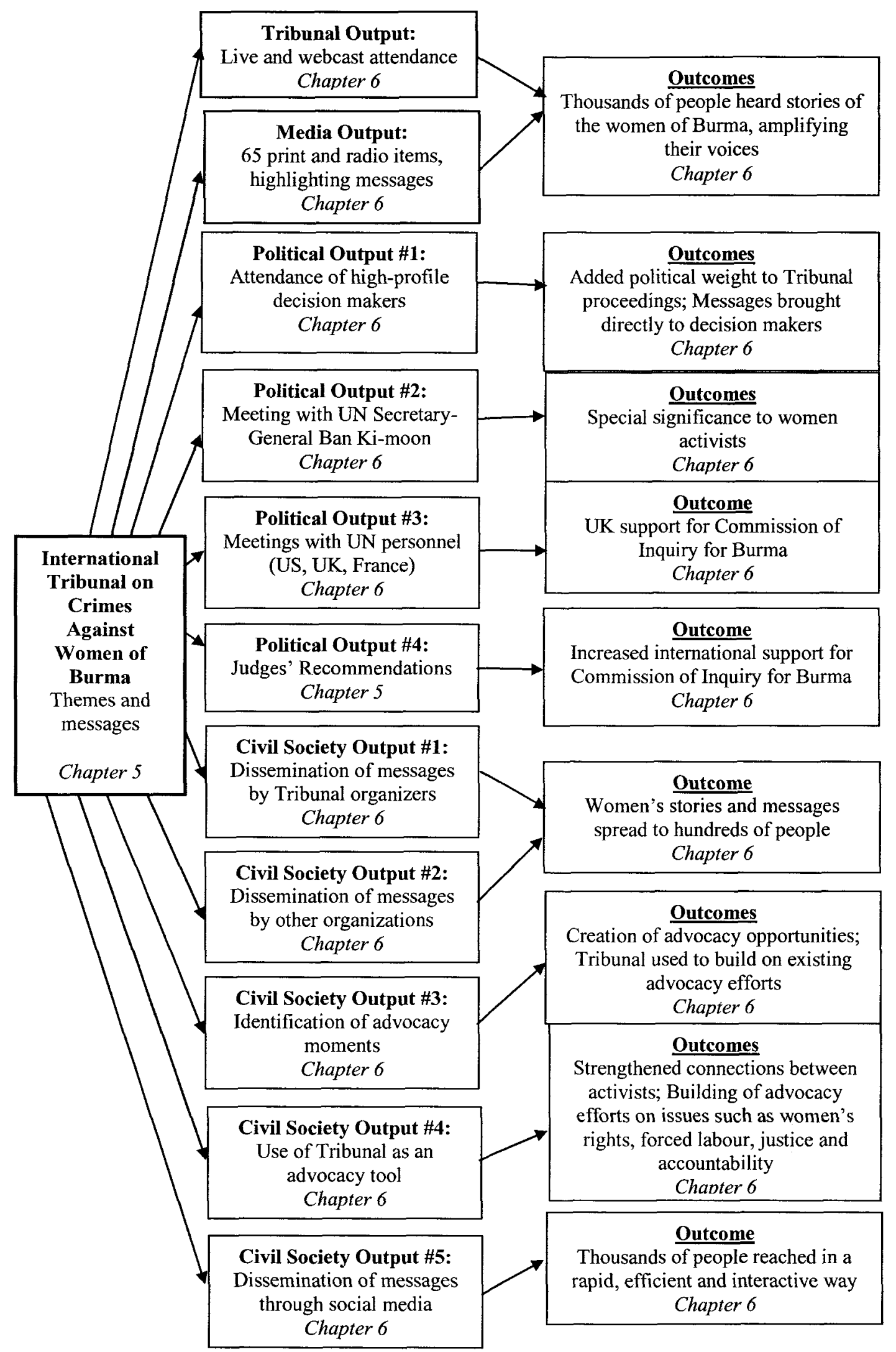


based, eight were printed in European sources, seven were printed in or broadcast from Australian sources, and six were found in North American news outlets. Of particular importance in the interest of amplifying the voices of the women of Burma, 24 of the documented news items were printed in or broadcast from Asian sources; at least six of these came from news sources with contributors in Burma - The Irrawaddy and Mizzima News. The full details of these media stories have been outlined in Appendix I.

As noted in Chapter 1, the collection of this data was limited to items available in English. Therefore, the 65 news items collected may not constitute a comprehensive representation of all the media published which made reference to the New York Tribunal. However, the data collected here did involve a broad and exhaustive online search. I would therefore argue that the collected data does constitute a comprehensive list of English-language media concerning the New York Tribunal.

In addition to spanning the globe, the media dissemination of the New York Tribunal spread over almost the entire period of interest in this case study. Media attention began well before the day of the Tribunal actually arrived. Indeed, articles referencing the Tribunal appeared as early as February 8, 2010, announcing the upcoming event. Following the release of the Tribunal Report in mid-May, news articles referencing the New York Tribunal continued to appear as late as June 28, 2010. It should be noted that news items may have appeared earlier or later than these dates, but for the purposes of this case study, I have only documented news items appearing between January 1 and July 12010 . Of the 65 print and radio media items documented, six appeared in February, 48 appeared in March, three appeared in April, two appeared in May, and 
another two items appeared in June. The exact publishing date of the final four news items was unknown, but I feel confident including them here because they refer to the New York Tribunal as having already happened, and were found before the July 1 end date of this case study.

It was not surprising that the vast majority of these news items were published or broadcast in March 2010. Media personnel from a variety of outlets were in attendance in New York, and the Tribunal judges discussed their findings and related recommendations with the media following the close of the Tribunal (Nobel Women's Initiative, 2010a). The judges also held a press conference on March 3, 2010, in a building across from the United Nations. At that press conference, the judges read the same statement of findings and recommendation with which they had closed the Tribunal. In this way, the media in attendance at the press conference heard the same message from the judges as those in attendance at the Tribunal itself, without any omissions. This consistency resulted in the media regularly referencing the judges' finding that the Burmese regime is guilty of gross human rights violations, crimes against humanity and war crimes. They also consistently refer to the judges' strong recommendation that the UN Security Council refer Burma to the International Criminal Court through the creation of a Commission of Inquiry.

It is important to note that a large number of the news items documented refer specifically to one or more of the stories of the Tribunal testifiers, or even quote the testifiers. For example, an article entitled "Nobel winners push for Myanmar regime to face court", initially published by Reuters and then reprinted in 11 other news outlets 
(including the New York Times and the Washington Post), begins with the following: "Rutha was pregnant when she was forced to serve as a porter at a military camp in Myanmar. There, she was raped nightly and her father killed when he refused to allow soldiers to take his 22-year-old daughter." The article later directly quotes Naw Ruth Tha's testimony (Nichols, 2010). Another article, entitled "Burmese Rape Survivors Speak Out", is comprised entirely of the stories of two of the Tribunal testifiers, with contextual analysis from Women's League of Burma Secretary-General Lway Aye Nang, one of the key organizers and session moderators of the Tribunal (Zaccaro, 2010). The article was initially published through the international news outlet IPS, and was then reprinted in three other sources, two of which are based in the Burma-Thailand region. This level of media attention granted explicitly to the voices of women of Burma works to significantly amplify their voices in the international arena and to increase awareness about the crimes committed against them.

Also found in a number of the media articles collected were some of the Tribunal themes identified in the previous chapter. An article entitled "Junta Should Go Before ICC, Nobel Laureates Tell Ban" pointed to the ways in which Burmese women activists have stood in solidarity with one another to demand action for justice in Burma. Reporter Lawi Weng writes, "Burmese women activists started their campaign to bring the junta before the ICC on charges of crimes against humanity in 2008. Since then, several ethnic women's organizations... have been collecting evidence of sexual violence, extrajudicial killings, torture and other abuses" (Lawi Weng, 2010). The article later quotes Khin Ohmar, the vice chairwoman of the Burmese Women's Union: "“Women's organizations and human rights groups along the Thai-Burmese border have collected enough evidence. 
Now we want the Security Council to set up an investigation commission to decide whether this evidence can be sent to the ICC or not"' (Lawi Weng, 2010).

Another article, an interview with Women's League of Burma leader and Tribunal organizer/moderator Hseng Noung published by the internationally-based IPS, also highlights Burmese women standing in solidarity with one another and demanding international action for justice. It begins, "Women who fled conflict and oppression in military-ruled Burma have become a potent political force during their lives in exile" (Macan-Markar, 2010). Later in this article, Hseng Noung articulates some of the work done by Burmese women activists to work for justice in their country:

'We have also proved ourselves by making people in the international community aware of the problems in Burma through our international networks. Before this people didn't know much about what the military regime was doing, using sexual violence and rape as a weapon of war. But we changed that view through the documentation work done by our member organisations, producing reports to expose these human rights violations. This helped to counter the propaganda of the regime' (Ibid).

In this same interview, Hseng Noung spoke to the need for peace to address human security needs, another of the cross-cutting themes from the New York Tribunal. She told the interviewer, “"The women talk the same language, that we want peace. But what kind of peace? Not just the absence of war. We want peace that offers better opportunities for all ethnic groups, for different people and different genders"' (Ibid). Similarly, in an April opinion piece arguing for further sanctions against the Burmese regime, reporter Eva Sundari wrote:

The benefits of foreign investment and trade have not reached the ordinary people of Burma. Instead poverty has increased and health spending has fallen, while the human rights crisis has peaked and so has sexual violence, torture and murder of women by military forces armed 
with newer weapons (Sundari, 2010).

It should also be noted that virtually all 65 of the print and radio media items collected articulate that the Burmese government are the perpetrators of gross human rights violations against the women and people of Burma. This is arguably the major theme of the International Tribunal on Crimes Against Women of Burma, and so it is significant that this message was echoed so widely and so often by the media. In successfully amplifying the voices and messages of the women of Burma to a wide attendee and media audience, the Tribunal thus contributed greatly to the advocacy efforts of the women of Burma.

\section{POLITICAL OUTPUTS AND OUTCOMES}

Teitel notes that there is a growing understanding that state persecution transcends national boundaries, and thereby implies international accountability (2000). The testimonies of the International Tribunal on Crimes Against Women of Burma illustrated that human rights violations are widespread both throughout Burma, and reaching beyond its borders. The testifiers, organizers and judges of the International Tribunal on Crimes Against Women of Burma thus sought to push for action from the Burmese military regime, from the United Nations and the international community, and from civil society. In holding the Tribunal in New York, the seat of the United Nations, organizers strove to reach out to a broad audience of powerful decision makers. An internal "After Action Report" of the Nobel Women's Initiative confirms, "It was definitely a strategic success to bring the message to where the policy makers are. An intangible but apparent factor 
was also the cache of New York City and its association with international and particularly UN decision making" (Nobel Women's Initiative, 2010a, p. 6).

The live audience in New York included some important political and high-profile political personnel, such as Thein Sein, Prime Minister in exile of Burma and head of the National Coalition Government of the Union of Burma; Melanne Verveer, US Ambassador-at-Large for Global Women's Issues; representatives from the Permanent Missions to the United Nations of the US and the Netherlands; and representatives from UN agencies and departments, including the Office of the Special Advisor on the Prevention of Genocide (Nobel Women's Initiative, 2010a). Having such high-profile decision makers in attendance added political weight to the Tribunal proceedings and brought the testifiers' stories and messages directly to those with significant power to affect change. While the presence of these leaders is indeed a significant achievement for the organizers of the New York Tribunal, it is important to examine what happened after the Tribunal was over. In this section, we will examine the political outputs and outcomes of the New York Tribunal.

\section{MEETING WITH UN SECRETARY-GENERAL BAN KI-MOON}

One particularly significant political outcome of the International Tribunal on Crimes Against Women of Burma occurred on March 3, the day following the Tribunal. Tribunal judges Jody Williams and Shirin Ebadi, along with Women's League of Burma presidium board member and Tribunal organizer Thin Thin Aung, met with UN Secretary-General Ban Ki-moon. The group brought to Secretary-General Ban the findings and recommendations of the Tribunal. They emphasized that sexual violence and 
other abuses against women in Burma are systematic and widespread, and that they can only be effectively addressed by referring the matter to the ICC. They asked the Secretary-General for his help in moving this process forward (Lawi Weng, 2010). For his part, Secretary-General Ban expressed strong support for ending violence against women in Burma. He indicated that he had sent a letter to General Than Shwe (head of the SPDC), urging him to make the upcoming elections "credible, inclusive and transparent" and to release all political prisoners - including Aung San Suu Kyi. Secretary-General Ban also noted that he was looking for a new Special Advisor on Burma (Nobel Women's Initiative, 2010b).

While the UN Secretary-General has yet to take tangible public action to push for a Commission of Inquiry for Burma, this meeting provided an important contribution to Burmese women's advocacy efforts. The meeting with Ban Ki-moon was the first meeting ever between a member of the Burma movement and a UN Secretary-General. The internal After Action Report of the Nobel Women's Initiative notes that the fact that this representative was a woman was "tremendously important to and meaningful for the woman activists" (Nobel Women's Initiative, 2010a, p. 3). Indeed, the chance to meet with the Secretary-General directly conveyed to the activists a new level of international interest in their movement, as well as a promise of sincere and tangible action (lbid).

\section{MEETINGS WITH UN SECURITY COUNCIL MEMBERS}

In addition to their meeting with UN Secretary-General Ban Ki-moon, Tribunal judges Jody Williams and Shirin Ebadi, as well as Burmese women activists, met with representatives from the Permanent Missions to the United Nations of the United States, 
the United Kingdom and France. As permanent members of the UN Security Council, these countries are considered key influential actors in global action on Burma. The Tribunal organizers also attempted to arrange a meeting with the UN Mission of Vietnam, then Chair of ASEAN, but the meeting was denied. Nonetheless, the meetings with UN Mission personnel provided the activists with an opportunity to speak privately with powerful leaders about Burma and about their willingness to condemn the Burmese regime and to take action towards a Commission of Inquiry. The Nobel Women's Initiative After Action Report also notes that these meetings were "an opening for women activists of Burma...to demand action personally and directly from international policy makers" (Nobel Women's Initiative, 2010a, p. 3).

It should also be noted that at least one of these meetings had a tangible outcome. Later in March 2010, the government of the United Kingdom became one of the first public supporters of a UN Commission of Inquiry on Burma. Mark Lyall Grant, British Ambassador to the UN, backed the recommendation by the UN's Special Rapporteur to Burma for a Commission of Inquiry to be established, and stated that the UK would support the referral of Burma to the International Criminal Court. Given the length of time such developments often take on the international scene, the public support of the UK for a Commission of Inquiry is a significant achievement. It should be noted that, since the close of the case study period, the US and France have also voiced public support for a Commission of Inquiry. 


\section{OTHER POLITICAL OUTCOMES}

On March 15, the UN Human Rights Commission Special Rapporteur on the situation of human rights in Myanmar, Tomás Ojea Quintana, presented his report, which had been published online a few days earlier. In this report, he documented a pattern of systematic, gross violations of human rights, which had been in place for many years and continue to the present. Among the human rights violations documented were forced labour and relocation, sexual violence and rape, the failure of due process in the Burmese justice system, and the abuse and torture of political prisoners, including sexual abuse (Quintana, 2010). In addition, just as the testifiers at the New York Tribunal emphasized that human insecurity acted as a barrier to women fully realizing their human rights, so too the Special Rapporteur noted, "For far too many of Myanmar's people their basic rights to food, shelter, health and education, which are not only human rights in and of themselves, but are also essential for the exercise of other human rights, are denied" (Ibid, p. 2).

Special Rapporteur Quintana also noted the "prevailing culture of impunity" aiding the perpetrators of these human rights violations and perpetuating the abuse of the civilian population in Burma (Ibid, p. 7). The report concludes that these human rights violations were the "result of a state policy that originate from decisions by authorities in the executive, military and judiciary at all levels" (Ibid, pp. 2-3). Quintana further concluded that these violations may constitute war crimes or crimes against humanity under international law, and recommended that the UN Security Council consider setting up a Commission of Inquiry in regard to international crimes in Burma (Ibid). 
This recommendation by a high-profile $\mathrm{UN}$ official is a significant step forward in the pursuit of justice in Burma. It should be noted that Special Rapporteur Quintana was sent the findings and recommendations of the New York Tribunal shortly after the conclusion of the Tribunal, and before the release of his report. Tribunal judge Vitit Muntarbhorn was also able to discuss the situation in Burma with Quintana prior to the release of the latter's report, when they were both at a meeting of the UN Human Rights Council (Nobel Women's Initiative, 2010a). In addition to his findings echoing those of the New York Tribunal, Special Rapporteur Quintana also acknowledged calls from "Nobel Laureates and other leaders" for action towards justice, particularly for the release of Aung San Suu Kyi and the other political prisoners of Burma (2010, p. 5). It is therefore likely that the findings and recommendations of the International Tribunal on Crimes Against Women of Burma directly contributed to the Special Rapporteur's endorsement of referring Burma to the International Criminal Court.

Following the release of Special Rapporteur Quintana's report, a number of countries have voiced public support for the creation of a Commission of Inquiry for Burma. The first to do so was the government of Australia, which took the international lead on March 17 by agreeing to investigate options for the establishment of a Commission of Inquiry; the decision was passed unanimously by the Australian senate (Nobel Women's Initiative, 2010a). One week earlier, Senator Scott Ludlum of the Green Party introduced a motion calling for this government action in which he cited two of the Tribunal's recommendations, noting, "an International Tribunal on Crimes against Women in Burma... recommended that the United Nations Security Council refer Burma to the 
International Criminal Court and that countries in the Asia-Pacific not invest in Burma's oil and gas industry" (Ludlum, 2010).

As mentioned above, the government of the United Kingdom followed Australia's lead in supporting a Commission of Inquiry later in March 2010. Two other countries have voiced public support for a Commission of Inquiry during the period of this case study. On April 8, the government of the Czech Republic announced: "The Czech Republic remains concerned at continuous grave human rights violations in Burma/Myanmar...We believe that the possibility of establishing a Commission of Inquiry should be seriously examined" (US Campaign for Burma, 2010). During a debate of the UN Human Rights Council on June 8, Slovakia became the fourth government to support a UN Commission of Inquiry (Mizzima News, 2010). Other countries have since added their support to the creation of a Commission of Inquiry, but these actions do not fall within the scope of this case study. Given the broad dissemination of the Tribunal findings and recommendations in the media and in civil society advocacy (discussed later in this chapter), it can be argued that the findings and recommendations of the Tribunal contributed to an increase in international support for a UN Commission of Inquiry for Burma.

As we have seen, there have been a number of political outcomes following the International Tribunal on Crimes Against Women of Burma. It is true that these outcomes cannot be linked solely to the Tribunal itself - advocacy efforts for Burma have been ongoing for years. However, it can be argued that the Tribunal has contributed to these results, as both Tribunal judges and organizers have taken the messages of the 
Tribunal to policy-makers and action has followed. In these ways, the New York Tribunal has contributed to the pursuit of justice for the women of Burma.

\section{CIVIL SOCIETY OUTPUTS AND OUTCOMES}

While the political outcomes discussed above are certainly important contributions of the New York Tribunal, they do not reflect its only impacts. The Tribunal audience was not only comprised of political officials. Indeed, as noted earlier, over 1000 people heard the women's testimony either live or via the webcast. Live audience members included students and professors from Cornell University, New York University, the City University of New York, the University of Melbourne, the University of San Diego, Rutgers University, York University, the University of Ottawa, the University of Toronto, Williams College, Chulalangkorn University in Thailand, and Harvard Law School. Also in attendance were members of major international human rights organization, including Rights and Democracy, WITNESS, the International Coalition for the International Criminal Court, the Open Society Institute, Amnesty International, and the International Campaign for Human Rights in Iran (Nobel Women's Initiative, 2010a).

We will now turn to the discussion of the outcomes and impact of the International Tribunal on Crimes Against Women of Burma within international civil society. I will begin by outlining the ways in which both the Tribunal organizers and other civil society groups spread information about the Tribunal and its findings. I will then examine the ways in which the organizers used the Tribunal as an advocacy tool for Burma, and in 
which other civil society groups used the Tribunal as a tool within their own advocacy efforts. Finally, I will discuss the important role played by online social media tools, including YouTube, Facebook and Twitter, in spreading the messages of the women of Burma and the New York Tribunal to the broader public.

\section{DISSEMINATING THE MESSAGE}

The Organizers: Nobel Women's Initiative and the Women's League of Burma

I have already outlined the extensive media attention garnered by the International Tribunal on Crimes Against Women of Burma. While media coverage undoubtedly played an important role in getting information about the women of Burma and about the Tribunal to the public, the Tribunal organizers did not rely solely upon the media for this purpose. Indeed, the Nobel Women's Initiative and the Women's League of Burma disseminated information about the New York Tribunal as well as the testifiers' stories through a range of internet-based tools.

First, both organizations posted news and information about the Tribunal on their websites, throughout the case study period. The Women's League of Burma website posted an announcement about the Tribunal, as well as links to the Tribunal report and to further information on the Nobel Women's Initiative site. Between the two organizing partners, the Nobel Women's Initiative website was the main site used for the purpose of publicizing information about the Tribunal. The organization posted five news stories about the Tribunal on its website, dated from February 12 to May 13, 2010. The earlier three stories announced the details of the upcoming Tribunal, and linked readers to further background information on the situation of the women of Burma, as well as to the 
Tribunal webcast. The later stories addressed some of the outcomes of the Tribunal, including the meeting with UN Secretary-General Ban Ki-moon and the May publishing of the Tribunal report, which was made available electronically on the website.

Second, the organizers set up a Tribunal blog, housed on the Nobel Women's Initiative website. The organizers made a total of 14 blog posts, between February 25 and May 18, 2010. While the stories on the main Nobel Women's Initiative website were formatted as news stories, the Tribunal blog post entries were more informal, and were particularly focused on allowing the public to get a more inside view of the Tribunal proceedings. The blogs posted prior to the Tribunal told the stories of the women of Burma and included photographs and a video. During the Tribunal itself, I was asked by the organizers to write a number of observational blog posts to bring the testimonies of the women to the public as the Tribunal was happening. All of these posts - four in total linked readers to the live Tribunal webcast. Following the Tribunal, blog posts provided the public with videos of the Tribunal and its testifiers, as well as with links to media coverage of the Tribunal and to the electronic Tribunal report. The Tribunal blog also linked to a Tribunal photo gallery, to the Nobel Women's Initiative YouTube channel, and to the main Nobel Women's Initiative website.

Third, the organizers of the New York Tribunal alerted their supporters to information about the Tribunal through newsletters distributed via email. Four email communications were sent to supporters by the Nobel Women's Initiative between February 26 and May 18, 2010. The first email announced the details of the Tribunal and invited supporters to watch the Tribunal in person or via the webcast. The second email, sent on the day of the 
New York Tribunal, reminded supporters to watch the Tribunal, and provided necessary details for attending the Tribunal in person or to connect to the live webcast. The third email was a regular newsletter sent to supporters of the Nobel Women's Initiative. It provided a summary of the Tribunal, linked supporters to further information about the Tribunal, and reminded them to look for the full report in the future. The fourth email communication alerted Nobel Women's Initiative supporters that the full Tribunal report was available and connected them to the electronic version.

As we have seen, the Nobel Women's Initiative and the Women's League of Burma used a variety of internet-based tools to spread the stories of the women of Burma, as well as information about the International Tribunal on Crimes Against Women of Burma, to a broad audience. With the exception of the email newsletters to supporters, all of this material, including the Tribunal webcast, remains available to the public. The full details of these online materials are included in Appendix I. It should also be noted that throughout all of the communications outlined above, the Tribunal organizers consistently linked the public to a variety of popular social media tools, including YouTube, Facebook, and Twitter. The use of these tools will be discussed in detail later, but first I will address the dissemination of information about the New York Tribunal by other civil society groups.

\section{Other Civil Society Organizations}

It is clear that the organizers of the International Tribunal on Crimes Against Women of Burma - the Nobel Women's Initiative and the Women's League of Burma made great efforts to spread information about the Tribunal, as well as the stories of the 
women of Burma, to the broader public. However, they were not the only organizations to do so. In this section, I will highlight the ways in which other organizations disseminated information about the New York Tribunal.

The New York Tribunal received a great deal of attention from organizations based around the world. In addition to the Nobel Women's Initiative and the Women's League of Burma, I was able to document 33 organizations that made reference to the Tribunal at least once in their online communication. Of these organizations, 13 were based in North America, 11 were internationally-based, five were based in Asia, and two organizations each were based in Europe and Australia. Two of the organizations documented also had a presence inside Burma. The organizations documented consistently provided information on how to watch the Tribunal and linked the public to more information at the Nobel Women's Initiative website. In this way, the stories and messages of the Tribunal testifiers were spread to a broad audience around the globe. The Tribunal also had a significant presence on a number of popular social media sites, including YouTube, Facebook and Twitter, which will be discussed in further detail below.

It should be noted here again that perhaps the major limitation of my research was my inability to speak or read languages other than English. This was particularly limiting in my search for information about the Tribunal broadcast or published in Asia. I must therefore emphasize here that the organizations I have documented may not be a complete list of those that disseminated information about the Tribunal. Even so, I feel that the list of organizations I was able to document illustrates that both the stories of the women of Burma and information about the New York Tribunal were available around 
the world. This spread of information on a global scale undoubtedly worked to contribute to advocacy efforts for Burma.

\section{CHOOSING MOMENTS: THE NEW YORK TRIBUNAL AS AN ADVOCACY TOOL}

The Organizers: Nobel Women's Initiative and the Women's League of Burma

We can see from our discussion above that the Nobel Women's Initiative and the Women's League of Burma have utilized the International Tribunal on Crimes Against Women of Burma as a tool in their broader advocacy efforts for Burma. Of course, getting the voices of the women of Burma out to the public is an important part of this advocacy. However, it is also important to note that in addition to disseminating information about the New York Tribunal, the Tribunal organizers have used Tribunal 'advocacy moments' to create other advocacy opportunities.

For example, the Tribunal organizers capitalized on the advocacy moment created by the release of the final Tribunal report. The organizers always intended to send this final report to a broad range of audiences - to supporters and funders of the Tribunal, to the organizations' close partners on Burma advocacy, and to a number of international leaders considered influential on Burma. These leaders included UN Secretary Ban Kimoon, the heads of state of the countries in the Association of Southeast Asian Nations (ASEAN), the members of the UN Security Council, US President Barack Obama and other US government officials, and UN Mission personnel from several countries. However, rather than send only the Tribunal report, the Tribunal organizers decided to take the opportunity to send cover letters advocating for some of the Tribunal judges' recommendations, particularly the referral of Burma to the International Criminal Court. 
These letters were meant to increase the chances that these leaders would be made aware of the messages and recommendations of the New York Tribunal, even if they did not take the time to read the Tribunal report itself.

The advocacy letters were made specific to their recipients. For instance, the letters sent to the UN Secretary-General and the UN Missions to the US, the UK and France, sought to follow up on the meetings that the Tribunal judges and activists had taken with these leaders in New York following the Tribunal. The letter to the UK Ambassador commended his country on its public support of a Commission of Inquiry and urged the UK to continue to take leadership on action for justice for Burma. The letters to the Ambassadors from the US and France thanked them for meeting with the Tribunal judges and activists, and asked that they turn these discussions into tangible action by joining the UK in supporting a Commission of Inquiry. The advocacy letter to UN SecretaryGeneral Ban Ki-moon has been included here in Appendix II.

Letters to partners, supporters and funders of the Tribunal emphasized the judges' recommendations to civil society. In particular, letters to Secretary-General Ban Kimoon, President Barack Obama, US Secretary of State Hillary Clinton, and to the heads of state of the ASEAN nations, were signed by the Nobel Peace Laureates who sat as New York Tribunal judges - Jody Williams and Shirin Ebadi. The other letters were signed jointly by Lway Aye Nang, Secretary-General of the Women's League of Burma, and Liz Bernstein, Executive Director of the Nobel Women's Initiative.

The Women's League of Burma has also used the New York Tribunal to create further advocacy opportunities. As noted above, the Women's League of Burma joined the 
Nobel Women's Initiative in sending advocacy letters to UN, ASEAN and other international decision-makers. They also built on the momentum created from the New York Tribunal to organize a second tribunal. This second tribunal was held on June 27, 2010 in Tokyo, Japan, and was also broadcast live on the internet via webcast. Japanese judges and lawyers heard testimony of women of Burma who have suffered violence at the hands of the Burmese military regime (Women's League of Burma, 2010).

It should be noted that one important advocacy moment occurred outside of the time period covered in this case study. In September 2010, the Nobel Women's Initiative and the Women's League of Burma released a documentary film about the International Tribunal on Crimes Against Women of Burma in New York City at the Paley Center for Media. The event - entitled "Burma and the Media: Amplifying Voices for Democracy" - also included a panel discussion on the role of global and social media in fuelling the pro-democracy movement in Burma (The Paley Center for Media, 2010). While this event falls beyond the scope of this case study, the Tribunal organizers used the advocacy moment created ahead of the upcoming national elections by the release of the Tribunal film to bring further public awareness to, and shape the conversation regarding, the ongoing political and humanitarian crises in Burma. In this way, the event provides another example of the Tribunal organizers utilizing the New York Tribunal in their ongoing advocacy efforts for Burma.

\section{Other Civil Society Organizations}

Just as the organizers of the International Tribunal on Crimes Against Women of Burma used the Tribunal as a tool in their broader advocacy efforts for Burma, so too did 
a number of other organizations use the New York Tribunal to build on their own advocacy efforts. As noted in the Nobel Women's Initiative After Action Report:

The timing of the Tribunal during the Commission on the Status of Women and the week before International Women's Day made it easy for women from all over the world to attend, meet and support the women of Burma as well as to draw linkages between the Tribunal to International Women's Day.

(Nobel Women's Initiative, 2010a, p. 3).

Indeed, the Global Fund for Women, Isis International, the Unrepresented Nations and Peoples Organization, the Pacific Gender Action Portal and the Pixel Project all reflected on the New York Tribunal in the context of the Commission on the Status of Women, connecting the Tribunal to their advocacy messaging around the need to advocate for justice and equality for women.

The Global Fund for Women reflected that "the voices of women rarely heard in these spaces stood out... the International Tribunal of Crimes Against Women of Burma was a unique opportunity for the testimonies of Burmese refugee women to be heard and shared internationally" (Arutyunova, Mukenge, \& Sengupta, 2010). Blogging for Isis International and the Pacific Gender Action Portal, Carole Shaw described the Tribunal as showing the strength and resilience of women, and argued for the promotion of safety, security and peace for all women (Shaw, 2010a; Shaw, 2010b). The Pixel Project highlighted the event in its violence against women-themed electronic newsletter, and encouraged readers to think about ways to end abuses against women (The Pixel Project, 2010). The Unrepresented Nations and Peoples Organization noted the ongoing human rights violations against Burma's ethnic minority populations and echoed the Tribunal judges' call for the international community to "actively engage with the peoples of 
Burma inside and outside the country" (Unrepresented Nations and Peoples Organization, 2010).

Other organizations focused on specific human rights violations discussed at the Tribunal. Burma Campaign Australia made reference to testifiers' accounts of forced labour and to the Tribunal judges' recommendation that countries should prohibit trade with Burma involving goods produced through forced labour and forced relocations. They issued a press release highlighting this particular recommendation as part of their advocacy for divestment from Burma. The March $4^{\text {th }}$ press release noted:

An International Tribunal on Burma called on countries in the Asia-Pacific region to avoid Burma's oil and gas industry, which use slave labour and forcibly relocates people... Australian company Twinza Oil is investing in Burma's lucrative oil and gas industry. Twinza Oil's project will earn the military regime an estimated US\$2.5 billion (Burma Campaign Australia, 2010).

The press release also highlighted that the New York Tribunal had heard testimony from 12 women who suffered rape, torture and other crimes at the hands of Burmese regime, and directed readers to Nobel Women's Initiative personnel for more information (Ibid).

Similarly, Burma Partnership and Threat to the Peace each used references to the New York Tribunal to build their advocacy case for UN Security Council action in their campaigns for accountability for crimes against humanity. In addition to publishing news items regarding the convening of the Tribunal and the publishing of its report, the Burma Partnership website page on its Crimes Against Humanity Campaign links to the Tribunal report (under Resources), as well as to the Nobel Women's Initiative and Women's League of Burma websites. The organization Threat to the Peace also drew attention to the Tribunal and its recommendation for a Commission of Inquiry under the "Updates" 
section of the organization's Criminal Accountability Campaign. In this way, these organizations used the messages and recommendations of the New York Tribunal to enhance their own advocacy campaigns on related Burma issues.

The US Campaign for Burma and the Alternative ASEAN Network on Burma (AltSEAN) also referenced the New York Tribunal in their campaigns for criminal accountability for crimes against humanity. In fact, the US Campaign for Burma created an entire web page dedicated to the New York Tribunal which is linked to their web page educating the public about crimes against humanity in Burma. Both organizations also used information about the Tribunal in communications sent out to supporters. AltSEAN included information regarding the Tribunal and Special Rapporteur Quintana's endorsement of a Commission of Inquiry in the thirty-ninth issue of their regularly distributed Burma Bulletin. The US Campaign for Burma sent three emails to supporters which made reference to the Tribunal. The first two invited supporters to watch the Tribunal testimony either in person or via webcast and provided them with the necessary details to do so. The third email was sent after the end of the Tribunal; it cited the Tribunal and its findings and recommendations, and asked supporters to build on this momentum by taking part in a US Campaign for Burma advocacy effort called "Arrest Yourself for Aung San Suu Kyi and Burma". The full details of the documented organizations using the New York Tribunal in their own advocacy efforts can be found in Appendix I.

In addition to its use in building on Burma advocacy campaigns, the Nobel Women's Initiative notes that the Tribunal process worked to strengthen the networks of those 
working on advocacy efforts for Burma. The Tribunal helped to raise awareness of the ongoing documentation work being done by the members of the Women's League of Burma and others as a resource for other international advocates. Activists working on Burma were connected with activists working on the International Criminal Court. Diaspora communities were connected to activists and to each other (Nobel Women's Initiative, 2010a). The New York Tribunal process thereby bolstered advocate connections for future efforts.

As we have seen, then, the International Tribunal on Crimes Against Women of Burma was not only used in advocacy efforts by its organizers, but was also used by organizations around the world to build on advocacy efforts for the people of Burma. The Tribunal process also served to strengthen the broader Burma advocacy networks around the world. In these ways, the Tribunal contributed significantly to the pursuit of justice for the women of Burma.

\section{SPREADING THE MESSAGE: SOCIAL MEDIA}

As I have noted throughout this chapter, the International Tribunal on Crimes Against Women of Burma had a significant presence on a number of popular social media sites. These included YouTube, Facebook and Twitter, the details of which can be found in Appendix I. These technologies are still new, and therefore the examination of their use in advocacy work is still in its infancy. However, given the increasing importance of these tools in popular media and in advocacy work, I feel it is important to address them here. 


\section{YouTube}

YouTube is an internet site which allows the public to view videos which have been posted by its users. It also allows anyone to post their own videos so that they can be viewed around the world. News media and advocacy organizations are increasingly utilizing YouTube to bring their work to the broader public. I have documented seven videos on YouTube which make reference to the International Tribunal on Crimes Against Women of Burma, and which were posted over the course of this case study. It should be noted that while all of the video titles were published in English, two of the videos are actually in Burmese. Five of the videos were posted by users in North America, while two were posted by users in Asia.

The Nobel Women's Initiative has its own channel on YouTube, and posted three of the videos found on the social media site. In the first of these videos, actress and activist Mia Farrow speaks about her experiences meeting Burmese women on an international delegation in 2008, and emphasizes the importance of the New York Tribunal in bringing attention to the stories of these women. This video has been viewed more than 1000 times. In the second video posted by the Nobel Women's Initiative, one of the Tribunal testifiers speaks about the courage of the women of Burma and the importance of the Tribunal in achieving justice for these women. This second video has been viewed over 2000 times. Finally, the third video the Nobel Women's Initiative posted was put together following the close of the Tribunal, and serves as a background video on the Tribunal itself, a sort of mini-documentary. This video has been viewed more than 150 times. 
The remaining four YouTube videos making reference to the New York Tribunal were posted by two sections of Voice of America News - its English and Burmese sections. Footage of the Tribunal, along with interviews with testifiers and judges, provide the viewer with an inside look at the event. The significance of having these stories also available in Burmese cannot be understated. While the webcast of the Tribunal was available in Burma, and was broadcast in Burmese as well as English, having Burmese news outlets bring attention to the Tribunal spreads the stories and the messages of the Tribunal to a wider public in Burma and in the Burmese diaspora. Indeed, the two Burmese Voice of America videos have been viewed over 1900 and over 2600 times, respectively. The two English news videos have been viewed over 60 and over 300 times, respectively.

While there may be some overlap in viewership of the YouTube videos, this does not undermine the fact that YouTube provided an important tool in the civil society impact of the International Tribunal on Crimes Against Women of Burma. There were still thousands of people who viewed the YouTube videos. Indeed, these videos provided an additional way for the public to hear the stories of the women of Burma from the women themselves, thereby amplifying the voices of the testifiers.

\section{Facebook}

Facebook provided another tool for disseminating the stories and messages of the International Tribunal on Crimes Against Women of Burma. Facebook is a social networking site that connects people and allows them to share information with one another. It is also increasingly used by advocacy campaigns to bring people's attention to 
various issues and to encourage them to take action. For example, the Nobel Women's Initiative maintains a page on Facebook where it posts news stories, event information and action items. These posts are shared with the page's followers, who totalled 804 on January 1, 1390 on March 1 and 2264 on July 1, 2010. These followers come from at least 20 countries, such as Canada, the US, the UK, Thailand, Burma, Indonesia, Australia, India, Mexico, Norway and South Africa. While these numbers do not reflect people following the New York Tribunal specifically, any information about the Tribunal posted on the Nobel Women's Initiative Facebook page would have been shared with all of the organization's Facebook followers. Facebook thus provides organizations with a way to reach a large number of people, across geographical boundaries, quickly and efficiently.

Including the Nobel Women's Initiative Facebook page, I have documented 15 Facebook pages on which the New York Tribunal was mentioned at least once over the course of this case study. These include both organizational Facebook pages and the individual Facebook pages of Nobel Women's Initiative Laureates and staff. The complete details of these Facebook pages have been included in Appendix I. The organizations that referenced the Tribunal on their Facebook pages included Burma Campaign Australia, Burma VJ (Norway), the International Tribunal on Crimes Against Women of Burma Event Page, the Nobel Women's Initiative, Support the Monks' Protest in Burma (Burma Global Action Network), and the US Campaign for Burma. Pages for Aung San Suu Kyi, Jody Williams, Shirin Ebadi and six current and former Nobel Women's Initiative employees were also documented. 
With the exception of Nobel Women's Initiative, I was unable to document where each page's followers or 'friends' came from, but I was able to document their numbers. Of particular note, the pages for Aung San Suu Kyi and for Support the Monks' Protest in Burma had over 200,000 and over 440,000 followers, respectively. The page for Shirin Ebadi had more than 21,000 followers. Even the individual pages of Nobel Women's Initiative staff had the potential to reach a large number of people - their pages averaged over 250 'friends'.

The information posted about the Tribunal was wide ranging. Organizations and individuals posted the Tribunal logo, news stories, videos and links to the Tribunal webcast and blog. The Nobel Women's Initiative page itself had 23 entries posted. These included information on how to view the Tribunal, repeated links to the webcast and Tribunal blog, as well as the videos posted on YouTube. The Nobel Women's Initiative also created a dedicated event page for the New York Tribunal. This page provided information on how to view the testimony, as well as links to the webcast, the Nobel Women's Initiative website and the Tribunal blog. The event page was used to send invitations to over 500 people on Facebook, further increasing the visibility of the event. While there may have been overlap among the follower of these various Facebook pages, it can safely be argued that thousands of people from around the world were connected to the stories and messages of the New York Tribunal over Facebook.

A few notes should be made here. First, Facebook users are able to set a variety of privacy settings which put limits on who can see the things that they post. This means that the Facebook pages documented here may not represent a complete list of those 
which made reference to the New York Tribunal, as I may simply be unable to view all of these pages. Second, Facebook is available to users in a large number of languages all over the world. Given that my language abilities are limited to English, there may well be pages in other languages that referenced the Tribunal without my being able to document them. In particular, pages by Burmese individuals or organizations were difficult to document. Third, while I posted information about the Tribunal on my own Facebook page, I have not included it in my documentation for this study. In this way, I aim to refrain from creating a conflict of interest.

Even given all of these considerations, however, it is clear that Facebook constituted an important tool in bringing the International Tribunal on Crimes Against Women of Burma to the public. Thousands of people around the world were exposed to the stories of the testifiers through this social networking site. There is no doubt, then, that Facebook contributed significantly to the civil society impact of the New York Tribunal.

\section{Twitter}

Twitter is the most recent social networking site to become an international phenomenon. Twitter users are able to build a network of those they are 'following' and of their 'followers'. The site is designed to allow users to post short updates (140 characters or less), on a frequent basis, thereby connecting to their followers in an up-tothe-minute way. An increasing number of non-governmental organizations have added Twitter to the communication tools they employ to engage the public. 
In addition to spreading information via website, email, YouTube and Facebook, the organizers of the International Tribunal on Crimes Against Women of Burma also reached out to the public on Twitter. While the Women's League of Burma does not have a Twitter page, the Nobel Women's Initiative maintains a Twitter account that has close to 1200 followers. Over the course of this case study, the Nobel Women's Initiative posted 41 updates or 'tweets' pertaining to the New York Tribunal, dated between February 17 and May 13, 2010. These tweets consistently linked users to the Tribunal blog, the Nobel Women's Initiative website, or to the webcast of the Tribunal itself. Particularly important to note, during the Tribunal itself, the Nobel Women's Initiative posted 20 live tweets. These tweets often quoted the testifiers or the judges, bringing the voices of the Tribunal directly to the broader public in an up-to-the-minute way.

As was the case with Facebook, the Tribunal organizers were not the only ones to spread the stories of the women of Burma on Twitter. In fact, I documented to references to the New York Tribunal on 49 other Twitter pages. These pages were based across the globe, in North America, Asia, Europe, Australia and Egypt, and included pages belonging to both organizations and individuals. A complete list of the documented Twitter pages can be found in Appendix I. A total of 17 Twitter users posted their own tweets regarding the New York Tribunal. Those posting their own tweets about the Tribunal had an average of 1495 followers. Another 33 Twitter users 're-tweeted' the Twitter updates of the Nobel Women's Initiative, literally spreading the messages of the New York Tribunal and the stories of the women of Burma. 
Like Facebook, then, Twitter allowed for information about the Tribunal and the stories of the women to be spread to thousands of people, across geographical boundaries, in an interactive and efficient manner. In this way, it contributed significantly to the civil society impact of the New York Tribunal. While Twitter is a relatively new communication tool, and the research exploring its impact is still young, it is clear that such social media sites may have a significant role in future advocacy efforts.

In this chapter, I have examined the outcomes and impact of the International Tribunal on Crimes Against Women of Burma - both political and in civil society. I reviewed the ways in which the Tribunal's messages were brought to powerful international leaders through the use of advocacy moments. I also highlighted the outcomes of these advocacy efforts, including international support for one of the judges' key recommendations: a Commission of Inquiry for Burma.

In addition to these political outcomes, this chapter examined the outcomes of the Tribunal in civil society. It is clear that the New York Tribunal was not only used in advocacy efforts by its organizers, but that the stories of the testifiers were also distributed by a network of advocacy organizations, spread across the world. Furthermore, this network of organizations used the New York Tribunal and its findings to build upon their own advocacy initiatives for Burma. In both its political and civil society outcomes, then, the International Tribunal on Crimes Against Women of Burma made an important contribution in amplifying the voices of women of Burma, and to the pursuit of justice for Burma. 
The examination of the use of social networking sites in advocacy provided a particularly interesting part of this case study. With their popularity on the rise, social media tools like YouTube, Facebook and Twitter connected thousands of people to the stories of the women of Burma, who may not have otherwise heard them. Social media was used both by the Tribunal organizers, as well as by other organizations and individuals, and enhanced the civil society impact of advocacy efforts for justice for Burma. Furthermore, social media sites connect people both to causes and to each other, helping to build and strengthen advocacy networks across boundaries. There is reason to believe that online social networking sites will play an important role in social justice advocacy as we look to the future. 


\section{Conclusion: Looking to the Future - Women Redefining Justice}




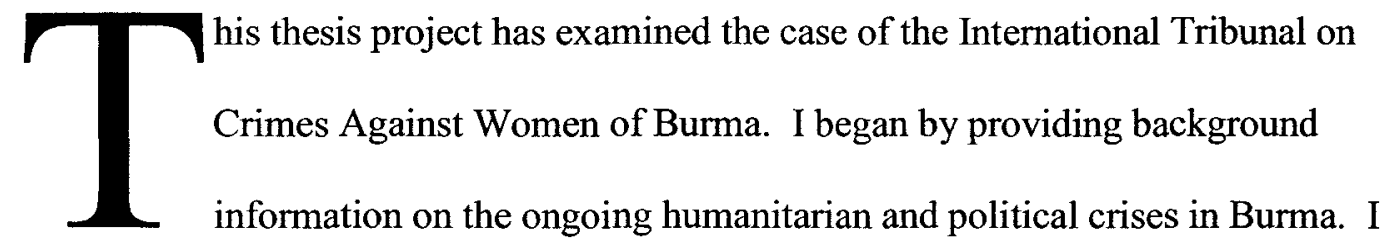
then developed a feminist framework through which to understand the human rights violations perpetrated against women of Burma. I highlighted women's differential experiences of armed conflict, their visions of what is required for peace, and the ways in which they show resilience and exercise agency, even in the face of violence and oppression. I examined the genealogy of women's tribunals in Vienna and Tokyo. In particular, I explored the testimonies of the New York Tribunal, and identified themes which emerged from these testimonies. Finally, I outlined the political and civil society outputs and outcomes of the International Tribunal on Crimes Against Women of Burma, especially highlighting the role of internet-based material and social media. The diagram on the following page, seen in Chapters 1 and 6, illustrates the chain of evidence employed in this thesis. In this chapter, I return to the research questions with which I began this thesis project. I will explore each of these in turn, drawing conclusions from the findings of this study, and will close by identifying recommendations for future research.

\section{CONTRIBUTION TO ADVOCACY EFFORTS}

I began this thesis project by asking how the International Tribunal on Crimes Against Women of Burma contributed to advocacy efforts for justice in Burma. In particular, I sought to identify the political outcomes of the New York Tribunal, as well as its civil society outcomes. I sought to discover how non-governmental organizations 


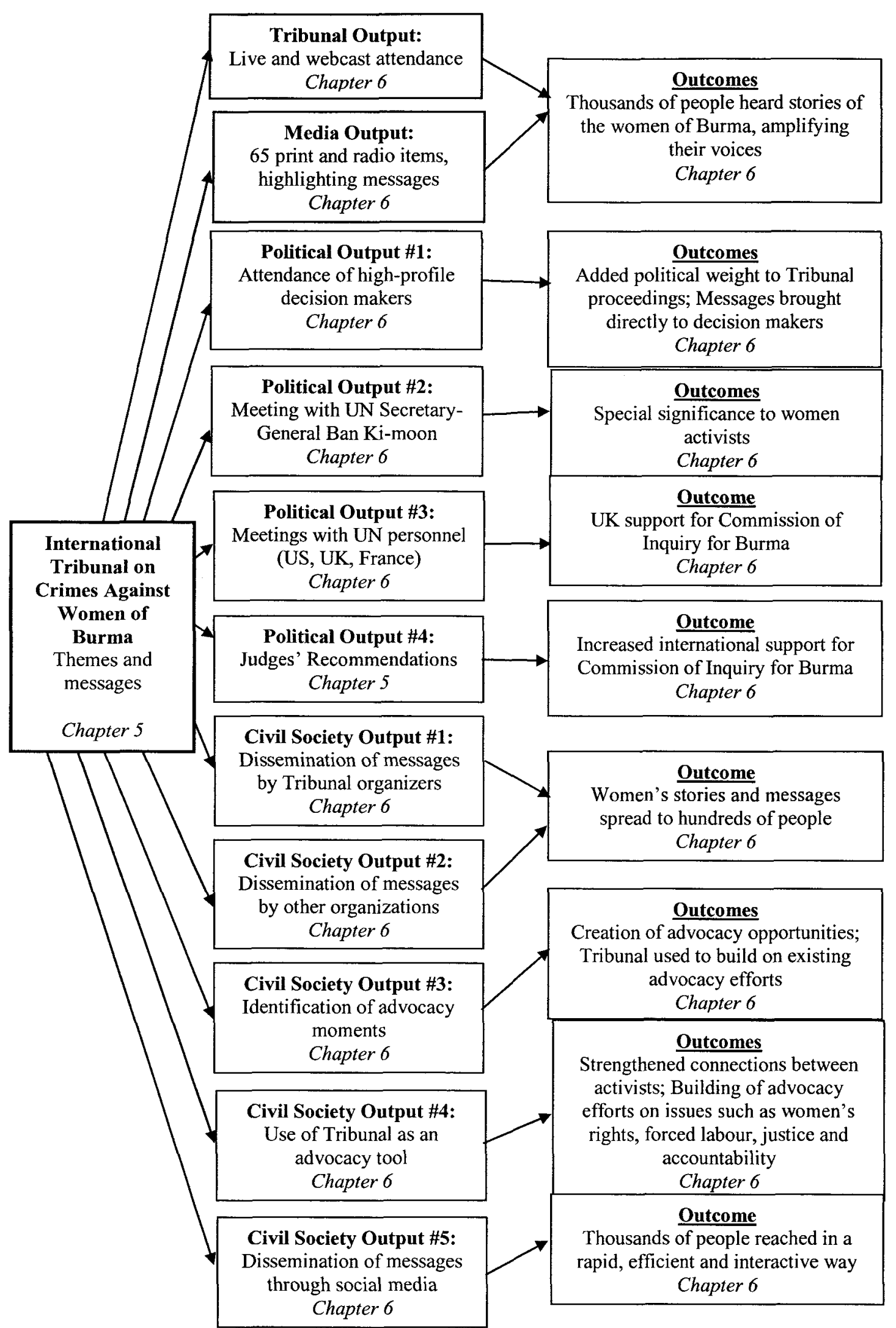


used the Tribunal to advance their own advocacy efforts. Finally, I inquired how the New York Tribunal contributed to women's advocacy efforts in particular.

As we have seen, the New York Tribunal had a number of political outcomes. To begin with, the live audience in New York included some important political and high-profile political personnel, such as Thein Sein, Prime Minister in exile of Burma and head of the National Coalition Government of the Union of Burma; Melanne Verveer, US Ambassador-at-Large for Global Women's Issues; representatives from the Permanent Missions to the United Nations of the US and the Netherlands; and representatives from UN agencies and departments, including the Office of the Special Advisor on the Prevention of Genocide. Having these powerful decision makers in attendance added political weight to the proceedings, and ensured the messages of the Tribunal testifiers were heard directly by those with the power to enact change.

Second, Tribunal judges Jody Williams and Shirin Ebadi, along with Women's League of Burma presidium board member and Tribunal organizer Thin Thin Aung, met with UN Secretary-General Ban Ki-moon. This group presented the Secretary-General with the findings and recommendations of the Tribunal. The meeting with Ban Ki-moon was the first meeting ever between a member of the Burma movement and a UN SecretaryGeneral. The fact that this representative was a woman was incredibly meaningful for the women activists, and conveyed a new level of international interest in their movement, as well as a promise of earnest, tangible action. 
Third, Tribunal judges Jody Williams and Shirin Ebadi, as well as Burmese women activists, met with representatives from the UN Missions of the United States, the United Kingdom and France. These meetings with UN Mission personnel provided an opportunity to speak privately with powerful leaders about Burma and their willingness to condemn the Burmese regime and to take action towards a Commission of Inquiry. It is particularly important to remember that the meeting with UK Ambassador Mark Lyall Grant had a tangible outcome: the UK declared their support for a Commission of Inquiry for Burma later in March 2010.

Finally, in the months following the New York Tribunal, there was increased support for the creation of a UN Commission of Inquiry for Burma, one of the Tribunal's key recommendations. On March 15, the UN Human Rights Commission Special Rapporteur on the situation of human rights in Myanmar, Tomás Ojea Quintana, presented his report, documenting a pattern of systematic, gross violations of human rights in Burma. Special Rapporteur Quintana recommended that the UN Security Council consider setting up a Commission of Inquiry in regard to international crimes in Burma. The Special Rapporteur was sent the findings of the Tribunal immediately after its close, discussed the Tribunal with judge Vitit Muntarbhorn, and in his report cited a number of the human rights violations described by the testifiers of the New York Tribunal. It is therefore likely that the International Tribunal on Crimes Against Women of Burma directly contributed to Special Rapporteur Quintana's endorsement of referring Burma to the International Criminal Court. 
Following the release of Special Rapporteur Quintana's report, a number of countries voiced public support for the creation of a Commission of Inquiry for Burma, including Australia, the UK, the Czech Republic and Slovakia. The short time between the New York Tribunal and the announcement of UK support for a Commission of Inquiry, as well as the fact that the Australian Senator Scott Ludlum cited the Tribunal in his motion calling for Australia's support for an International Criminal Court referral, point to the New York Tribunal as a contributing factor in these actions. Thus, we can see that the International Tribunal on Crimes Against Women of Burma had real political outcomes.

I have also explored above a number of civil society outcomes resulting from the International Tribunal on Crimes Against Women of Burma. Over 1000 people heard the women's testimony either live or via the webcast. Among the members of the live Tribunal audience were students and professors from a large number of universities, as well as members of major international human rights organizations. In addition, I documented 62 print news articles and three radio broadcasts which mention the New York Tribunal and which come from sources spanning across the globe.

A large number of the news items documented refer specifically to one or more of the stories of the Tribunal testifiers, or even quote the testifiers. Also found in a number of the media articles collected were a number of the themes which emerged from the Tribunal testimony, including the ways in which Burmese women activists have stood in solidarity with one another to demand action for justice in Burma, the need for peace to address human security needs, and the identification of Burmese regime personnel as the perpetrators of gross human rights violations against the women and people of Burma. It 
is clear, then, that the stories of the women of Burma reached a large number of people across a broad geographical area, significantly amplifying their (too often marginalized) voices in the international arena and increasing awareness about the crimes committed against them. In this way, the New York Tribunal contributed to the advocacy efforts of the women of Burma.

I also outlined the civil society outcomes related to the use of the New York Tribunal as an advocacy tool. These included both outcomes of the work of the Tribunal organizers, as well as outcomes in the broader Burma advocacy network, through the dissemination of the messages of the Tribunal and through the use of the Tribunal as a tool in advocacy efforts. Also important to note were the civil society outcomes related to relatively new advocacy tools - social media sites such as YouTube, Facebook and Twitter.

The New York Tribunal organizers - the Nobel Women's Initiative and the Women's League of Burma - disseminated information about the New York Tribunal and the testifiers' stories through a range of internet-based tools. These tools included the organizations' websites, as well as a dedicated Tribunal blog and email-based newsletters. The New York Tribunal also received a great deal of attention from organizations around the world. In addition to the Nobel Women's Initiative and the Women's League of Burma, I was able to document 33 organizations, based across the globe, which made reference to the Tribunal at least once in their online communication.

The Tribunal organizers also identified opportunities created by advocacy moments, and used the messages of the New York Tribunal as a tool in their advocacy efforts. In one example, the Tribunal organizers capitalized on the advocacy moment created by the 
release of the final Tribunal report. The Tribunal organizers took the opportunity to send letters, along with copies of the Tribunal report, to a large number of decision-makers, advocating for some of the Tribunal judges' recommendations, particularly the referral of Burma to the International Criminal Court. The Women's League of Burma also built on the momentum created from the New York Tribunal to organize a second tribunal, held in June 2010 in Tokyo, Japan.

Just as the organizers of the International Tribunal on Crimes Against Women of Burma used the Tribunal as a tool in their broader advocacy efforts for Burma, so too did a number of other organizations use the New York Tribunal to build on their own advocacy efforts. The scheduling of the Tribunal to coincide with the UN Commission on the Status of Women allowed a number of organizations to connect the Tribunal to their advocacy messaging around the need to advocate for justice and equality for women. Other organizations used the Tribunal as a reference point in their advocacy for measures related to forced labour, as well as for UN Security Council action regarding accountability for crimes against humanity in Burma, including the establishment of a Commission of Inquiry.

Furthermore, the Tribunal process strengthened the networks of those working on advocacy efforts for Burma by connecting activists and Burmese diaspora communities from around the world, and raising awareness of the work being done by Burmese women on the ground. These bolstered connections will provide women with greater opportunities for effective advocacy in the future. In all of these ways, the Tribunal contributed significantly to the pursuit of justice for women of Burma. 
Finally, social media sites including YouTube, Facebook and Twitter, played an important role in the civil society outcomes of the International Tribunal on Crimes Against Women of Burma. Thousands of people have viewed the seven videos available on YouTube which bring the voices of the testifiers directly to the viewers. While the webcast of the Tribunal was available in Burma, and was broadcast in Burmese as well as English, having Burmese news outlets bring attention to the Tribunal likely spread the stories and messages of the Tribunal to a wider public in Burma and in the Burmese diaspora.

Including the Nobel Women's Initiative Facebook page, I have documented 15 Facebook pages on which the New York Tribunal was mentioned at least once over the course of this case study. Organizations and individuals posted the Tribunal logo, news stories, videos and links to the Tribunal webcast and blog. The dedicated Tribunal event page was used to send invitations to over 500 people on Facebook, further increasing the visibility of the event. It can safely be argued that thousands of people from around the world were connected to the stories and messages of the New York Tribunal over Facebook, constituting a major contribution to advocacy efforts for Burma.

I also documented to references to the New York Tribunal on 50 Twitter pages, again based across the globe. Like Facebook, Twitter allowed information about the Tribunal and the stories of the women to be spread to thousands of people, across geographical and other boundaries, in an interactive and efficient manner. As we have seen, these social media sites contributed significantly to the civil society impact of the New York Tribunal. Given that women's voices are largely marginalized around the world, it can 
be argued that these more 'democratic' tools also contribute to women's advocacy in particular.

\section{POSSIBILITIES FOR WOMEN REDEFINING JUSTICE}

In beginning this thesis project I also asked, based on the analysis of the single case of the New York Tribunal, what potential role popular tribunals might have in future advocacy efforts. In particular, I asked how popular tribunals might contribute to the pursuit of justice for women. I also sought to discover how civil society, including social workers, might contribute to these efforts. Finally, I sought to identify some lessons learned for the future.

Posel writes that truth commissions work to write and present public histories in a way that puts the pursuit of truth in the centre of brokering peace and transcending brutal pasts (2008). Indeed, Minow argues that tribunals look both into the past and towards the future (1998). In other words, these initiatives acknowledge past violations, while recognizing that this acknowledgement is a key component of sustainable peace in the future. While both of these authors are writing about official tribunals and truth commissions, I would argue that popular tribunals can serve the same purpose. Indeed, the testifiers at the International Tribunal on Crimes Against Women of Burma made it clear that the recognition of the wrongs done to them is necessary for sustainable peace and security moving forward.

Popular tribunals in particular can also serve another purpose: they can provide a space for testimony about human rights violations when the political peace process is stalled or 
non-existent. In many cases, prosecution has been seen as both a hindrance to peace negotiations and a threat to fragile peace (Minow, 1998). Although the ongoing and systemic human rights violations in Burma have been well documented, the military regime remains resistant to international pressure for change. UN Security Council action has so far been blocked by the regime's political and economic partners, Russia and (in particular) China. However, the International Tribunal on Crimes Against Women of Burma acted both as a space for women to have their stories heard and acknowledged, and as a catalyst for future action. Indeed, a Commission of Inquiry for Burma has received increasing support from influential decision-makers. It can be argued, then, that popular tribunals can be a useful complement to official prosecutions, as well as important advocacy tools.

The case of the International Tribunal on Crimes Against Women of Burma also illustrated that popular tribunals can serve as important tools in women's advocacy in particular. I explored at the outset of this thesis the ways in which women's voices are often marginalized in the international arena. The New York Tribunal provided a way for the voices of the women of Burma to be heard by thousands of people around the world. Gardam notes that "the major underlying cause of the particular vulnerability of women in armed conflict - namely the endemic discrimination that exists against women in all societies - is consistently overlooked in any discussion of international humanitarian law and is not addressed in its provisions" (2005, p. 118). In their Tribunal testimonies, the women of Burma were able to articulate the ways in which gender discrimination manifested in the human rights violations they suffered, including in sexual violence. They were also able to speak about the experiences of their 
communities, and the human insecurity that made them more vulnerable to, and resulted from, human rights abuses.

Furthermore, the International Tribunal on Crimes Against Women of Burma effectively amplified the voices of women exercising agency and acting in resistance to their oppression. The widespread dissemination of the Tribunal messages therefore worked to mitigate the marginalization of women's voices and promoted the reality of women's agency and resiliency. Kelly argues that it is important to emphasize women's agency, not only in taking up arms, but also in resistance and coping (2000). Popular tribunals can provide a space for women's stories to be heard and allow women to shape the international discourse regarding human rights, peace and security. In all of these ways, I would argue, popular tribunals can contribute to women's advocacy efforts in the future.

Of course, at the core of any popular tribunal is civil society. Indeed, individuals and organizations have an important role to play in future advocacy efforts involving popular tribunals. Non-governmental organizations may have a particularly important role in collecting information on violence against women, including the collection of testimonies about atrocities (Pickup, Williams, \& Sweetman, 2001). Minow, too, sees nongovernmental organizations as an important factor in creating a demand for truth and justice (1998). Cubilié argues that "testimony and the responsibilities of justice and ethics are...about what we are willing do as witnesses to the witnesses" $(2005$, p. 3$)$. In the case of the International Tribunal on Crimes Against Women of Burma, civil society designed and implemented the Tribunal; recruited and acted as testifiers, audience members and judges; and spread the messages of the Tribunal through media, internet- 
based material and related advocacy efforts, significantly amplifying the voices of the women of Burma.

Such work can make important contributions. Indeed, civil society work has already had great impact on the international law and international human rights discourses. Durham notes: "The decentralization of the authority of the state has facilitated the growth of NGOs pursuing goals that transcend national and local identities... The lofty aim of changing the culture of impunity to a culture of accountability will not be achieved without the carefully considered assistance of NGOs" (2004, p. 183). In addition to the achievements of the Vienna Tribunal, discussed earlier, it should also be noted that nongovernmental organizations acted as a significant catalyst in the creation of the International Criminal Tribunal for the Former Yugoslavia, the International Criminal Tribunal for Rwanda, and the International Criminal Court (Ibid). In the case of Burma, UN Security Council action on an ICC referral has never been more likely than it is following the New York Tribunal.

There is another role for civil society as well - as active audience members in the testimonial process. Cubilié emphasizes that witnesses to acts of atrocity cannot be alone in the testimonial act - they need an audience of some kind (2005). Madam Justice and former UN High Commissioner for Human Rights, Louise Arbour contends, "More even than the punishment of the perpetrator, it is the process itself, from beginning to end, that speaks the language of peace. The integrity of the criminal justice system...tells us about who we are and how we live" (2002, p. 32). Minow, too, asserts, "Living after genocide, mass atrocity, totalitarian terror...makes remembering and forgetting not just about 
dealing with the past. The treatment of the past through remembering and forgetting crucially shapes the present and future for individuals and entire societies" (Minow, 1998, p. 119). In other words, civil society, including both individuals and organizations, must engage with truth-telling processes about the past in order to move forward and build sustainable peace and human security in the future. The case of the International Tribunal on Crimes Against Women of Burma points to popular tribunals, created and organized by civil society, as important opportunities for this engagement, particularly in cases where governments have been slow to act for justice.

The need for civil society engagement in justice processes also has implications for social work. Social workers are a significant force in civil society around the world. In the past 20 to 30 years, the discourse on international social work has come to revolve closely around the idea that globalization has changed the reality of the world in such a way that subsequent change is required in the social work profession in order to respond to this reality. Indeed, in a globalized world, social problems at the local or national level may have international factors contributing to them. The ongoing conflict in Burma could certainly be described in this way, as international actors fund and protect the Burmese regime against international pressure. Hokenstad and Midgley argue that the realities of global interdependence demand an increased emphasis on the international dimension of social work and human services (1997).

Others contend that if problems exist in an international pattern, adequate solutions to these problems may require international action (Wagner, 1997; Ife, 2000). Ife argues that as social workers we must move away from what he calls the "global/local dialectic" 
and instead link the two areas, potentially by drawing the connection between human rights and human needs (Ife, 2000, p. 59). Like these authors, I see an important role for social workers in international social justice advocacy. Indeed, our commitment to the pursuit of social justice for all cannot be limited to a national context. This is particularly the case in regard to human rights violations and threats to peace and human security, which both impact upon and result from international factors.

Torczyner argues that there is a clear link between globalization, inequality, and the escalation of violent conflicts within and between countries. Furthermore, he points out that war and violence are of greater threat to the poor than they are to other segments of society, making conflict a relevant concern for social workers (2000). Mehta also sees a responsibility for social workers in peacebuilding. She argues that "peace is everybody's concern. Social workers, who stand for human dignity, freedom and justice, have a professional obligation to contribute to global security and international cooperation" (1997, p. 107). As we have seen in the case of the International Tribunal on Crimes Against Women of Burma, the conflict in Burma indeed poses an increased threat to the more disadvantaged sectors of society, including ethnic minorities, the poor and women. Mehta identifies several levels for potential social work intervention, including the world community, nation states, regions, districts, communities, families and individuals. Furthermore, she argues that intervention strategies must be versatile (Ibid). From the example of this case study, I would argue that popular tribunals pose an opportunity for such versatile intervention. 
Before I conclude by identifying recommendations for future research, it is important to note a number of key lessons learned for future advocacy efforts in my examination of the case of the International Tribunal on Crimes Against Women of Burma. First, the case of the New York Tribunal illustrates that bringing an advocacy event to decision makers, rather than holding it far away, can be effective in moving one's messages forward. The Tribunal organizers themselves noted that holding the Tribunal in New York, near the United Nations, and coinciding with the Commission of the Status of Women significantly increased the amount of attention the event received, and provided added political weight to the proceedings. Furthermore, holding the Tribunal in New York meant that the judges and activists could arrange face-to-face meetings with powerful political figures immediately following the Tribunal. We have seen above that these meetings had tangible outcomes towards justice for the women and people of Burma: increased support for a UN Commission of Inquiry.

Second, the case of the International Tribunal on Crimes Against Women of Burma has demonstrated the importance of identifying and taking advantage of advocacy moments. As seen in the example of the Vienna Tribunal, the utilization of these advocacy moments can have significant impacts. The timing of the Vienna Tribunal to coincide with the UN World Conference on Human Rights led to the creation of the Vienna Declaration and the appointment of a Special Rapporteur on Violence Against Women by the UN Commission on Human Rights. In the case of the New York Tribunal, both the Tribunal organizers and the broader Burma advocacy network utilized the Tribunal as a tool to build upon their advocacy efforts for the people of Burma. The Tribunal event itself, as well as the release of the Tribunal report, provided opportunities for advocates to 
amplify the voices of the women of Burma, as well as their own advocacy messages. Identifying and making use of important advocacy moments should be a key strategy in future advocacy efforts.

Third, the case of the New York Tribunal highlighted the growing impact of online social media tools, such as YouTube, Facebook and Twitter. Indeed, these social media sites brought the stories and messages of the Tribunal to thousands of people across the globe. I would argue that many of these people may not have otherwise been connected to the Tribunal at all. Social media tools therefore allow advocates to reach out to more people, quickly and efficiently. As interactive tools, these sites also allow the public to become involved in advocacy in new ways. While social media sites are relatively new, and their use in advocacy is still in its infancy, their increasing popularity indicates that they will be important tools in future advocacy efforts.

Finally, the International Tribunal on Crimes Against Women of Burma demonstrated that women's advocacy efforts can effectively challenge hierarchical social relations, even in the face of atrocity. I have noted throughout this paper the many ways in which women's voices and stories of armed conflict are often marginalized in the international arena. Lamb argues that sharing women's experiences is a way of bringing a fuller range of accounts of reality, thereby challenging male authority as arbiters of history (1999). Broadhead further notes:

The central point of any feminist analysis is not merely about 'adding' women to the list of important subjects to be considered and still less about merely offering platitudes about the importance of women in society; it is instead about looking at the hierarchical social relations (including gender relations) which lead to the injustices so prevalent in 
our world and the institutions and organizations that, either inadvertently or by design, perpetuate them (Broadhead, 2000, p. 31).

Not only did the New York Tribunal highlight women's voices and experiences, it also pointed to the inequality that contributed to and perpetuated the violations they suffered. Furthermore, the Tribunal and its subsequent publicity challenged the image of women as solely victims in male-dominated conflict by emphasizing women's solidarity, resiliency and resistance. Hannah Arendt wrote that "a trial resembles a play in that both begin and end with the doer, not with the victim" (Nikolic-Ristanovic, 2005, p. 285). Minow argues that the trial's focus on the offender, rather than on the victim, may work to impede the emergence of truth (1998). The case of the New York Tribunal has demonstrated that it is possible, through creative advocacy efforts, to re-focus the attention of justice processes and to make them survivor-centred. This lesson has particular significance for women's advocacy moving forward.

\section{RECOMMENDATIONS FOR FURTHER RESEARCH}

This case study on the International Tribunal on Crimes Against Women of Burma has been exploratory in nature, due to the fact that women's tribunals, and the research done on them, are relatively new. While it is my hope that this thesis has made some contribution to the literature, there is certainly more work to be done. In particular, the completion of this thesis has led me to recommend further research in three areas. To begin, there is a need for further research regarding popular tribunals, especially women's tribunals. Much of the literature I found pertains to official tribunals and truth commissions. While in many cases these are similar in nature to popular tribunals, they 
are nonetheless distinguished by their legal enforceability. Popular tribunals also provide unique opportunities for civil society engagement in the pursuit of justice. More research should be done on the potential impacts, outcomes and contributions to justice of popular tribunals.

Second, following from one of the limitations of this study, further research should be done on the International Tribunal on Crimes Against Women of Burma. In particular, further research should be done to include data collection in a broader range of languages. Research in which data was collected in Burmese or Thai would be especially useful, as such research would speak more directly to potential Tribunal outcomes within Burma and across the southeast Asian region. Such research would contribute to knowledge of how Burmese women's voices were disseminated into the world through the New York Tribunal.

Finally, the case of the International Tribunal on Crimes Against Women of Burma made clear that internet-based tools, especially including social media, are becoming increasingly important in international social justice advocacy. As noted above, these tools and their use in advocacy efforts are still in their infancy. Further research should be conducted on the uses and impacts of these internet-based tools in advocacy efforts around the world. 


\section{Bibliography}

(2009, December 2). Retrieved December 5, 2009, from Association for the Assistance of Political Prisoners (Burma): http://www.aappb.org/

Amnesty International. (2009). Human Rights in Union of Myanmar - Report 2009. Retrieved June 18, 2010, from Amnesty International: http://www.amnesty.org/en/region/myanmar/report2009

Arbour, L. (2002). War Crimes and the Culture of Peace. Toronto: University of Toronto Press.

Arutyunova, A., Mukenge, M., \& Sengupta, A. (2010). Looking Back, Moving Forward:

Reflections on the 54th Session of CSW and Beijing +15. Retrieved June 15, 2010, from Global Fund for Women: http://www.globalfundforwomen.org/what-we-

do/publications/newsletters/spring-2010/1658-looking-back-moving-forward-reflections-on-the54th-session-of-csw-and-beijing 15

Baines, E. K. (2009). Complex political perpetrators: reflections on Dominic Ongwen. Journal of Modern African Studies , 47 (2), 163-191.

Brandell, J. R., \& Varkas, T. (2010). Narrative Case Studies. In B. Thyer (Ed.), The Handbook of Social Work Research Methods, 2nd Edition (pp. 376-396). Thousand Oaks, CA: Sage

Publications, Inc.

Broadhead, L. (2000). Re-packaging Notions of Security: A Sceptical Feminist Response to Recent Efforts. In S. Jacobs, R. Jacobson, \& J. Marchbank (Eds.), States of Conflict: Gender, Violence and Resistance (pp. 27-44). London: Zed Books.

Brunet, A., \& Rousseau, S. (1998). Acknowledging Violations, Struggling Against Impunity: Women's Rights, Human Rights. In I. L. Sajor (Ed.), Common Grounds: Violence Against Women in War and Armed Conflict Situations (P. Feldstein, Trans., pp. 33-60). Quezon City, Philippines: Asian Center for Women's Human Rights (ASCENT).

Bunch, C., \& Reilly, N. (1994). Demanding Accountability: The Global Campaign and Vienna Tribunal for Women's Human Rights. New York: UNIFEM.

Burma Campaign Australia. (2010, March 4). BCA Media Release: International Tribunal: Avoid Burma's oil and gas industry - it uses slave labour. Retrieved April 10, 2010, from Burma Campaign Australia: http://www.aucampaignforburma.org/BCANews.htm

Buzan, B., \& Hansen, L. (2009). The Evolution of International Security Studies. New York: Cambridge University Press. 
Carpenter, R. C. (2007). Gender, Ethnicity, and Children's Human Rights: Theorizing Babies Born of Wartime Rape and Sexual Exploitation. In R. C. Carpenter (Ed.), Born of War:

Protecting Children of Sexual Violence Survivors in Conflict Zones (pp. 1-20). Bloomfield, CT:

Kumarian Press, Inc.

Center for Women's Global Leadership. (1994). Testimonies of the Global Tribunal on Violations of Women's Human Rights at the United Nations World Conference on Human Rights. Highland Park, New Jersey: Plowshares Press.

Chinkin, C. (2004). Gender-related crimes: A feminist perspective. In R. Thakur, \& P. Malconent, From sovereign impunity to international accountability (pp. 116-134). Tokyo: United Nations.

Chinkin, C. M. (2001). Women's International Tribunal on Japanese Military Sexual Slavery. The American Journal of International Law, 95 (2), 335-341.

Cockburn, C. (2007). From Where We Stand: War, Women's Activism and Feminist Analysis. London: Zed Books.

Coomaraswamy, R. (2005). Sexual Violence during Wartime. In H. Durham, \& T. Gurd (Eds.), Listening to the Silences: Women and War (pp. 53-66). Leiden, The Netherlands: Martinus Nijhoff Publishers.

Cubilié, A. (2005). Women witnessing terror: Testimony and the cultural politics of human rights. New York: Fordham University Press.

Denov, M., \& Gervais, C. (2007). Negotiating (In)Security: Agency, Resistance, and Resourcefulness among Girls Formerly Associated with Sierra Leone's Revolutionary United Front. Signs: Journal of Women in Culture and Society, 32 (4), 885-910.

Durham, H. (2004). We the people: The position of NGOs in gathering evidence and giving witness at international criminal trials. In R. Thakur, \& P. Malcontent (Eds.), From Sovereign Impunity to International Accountability: The Search for Justice in a World of States (pp. 169. 186). Tokyo: United Nations University Press.

Edwards, A. (2006). The 'Feminization' of Torture under International Human Rights Law. Leiden Journal of International Law , 19, 349-391.

Enloe, C. (2000). When soldiers rape. In C. Enloe, Maneuvers: The international politics of militarizing women's lives (pp. 108-152). Berkeley: University of California Press.

Fawcett, B., \& Featherstone, B. (2000). Setting the scene: An appraisal of notions of postmodernism, postmodernity and postmodern feminism. In B. Fawcett, B. Featherstone, J. Fook, \& A. Rossiter (Eds.), Practice and Research in Social Work: Postmodern feminist perspectives (pp. 5-23). London: Routledge. 
Fung, L. (2005). Engendering the Peace Process: Women's Role in Peacebuilding and Conflict Resolution. In H. Durham, \& T. Gurd (Eds.), Listening to the Silences: Women and War (pp. 225241). Leiden, The Netherlands: Martinus Nijhoff Publishers.

Gardam, J. (2005). Women and Armed Conflict: The Response of International Humanitarian Law. In H. Durham, \& T. Gurd (Eds.), Listening to the Silences: Women and War (pp. 109-123). Leiden, The Netherlands: Martinus Nijhoff Publishers.

Goetz, A. M. (10 May 2009). The good, the bad and the ugly about democracy for women. Nobel Women's Initiative 2nd International Conference: Women Redefining Democracy. Antigua, Guatemala.

Havel, V., \& Tutu, D. (2005). Threat to the Peace: A Call for the UN Security Council to Act in Burma. Washington, DC: DLA Piper Rudnick Gray Cary US LLP.

Hayner, P. (2002). Truth versus justice: Is it a trade off? In P. Hayner, Unspeakable truths: Facing the challenges of truth commissions (pp. 86-106). New York: Routledge.

Healy, L. M. (2001). International Social Work: Professional Action in an Interdependent World. New York: Oxford University Press.

Hokenstad, M. C., \& Midgley, J. (1997). Realities of Global Interdependence: Challenges for Social Work in a New Century. In M. C. Hokenstad, \& J. Midgley (Eds.), Issues in International Social Work: Global Challenges for a New Century. Washington, D.C.: NASW Press.

Human Rights Watch. (2010, January). World Report Chapter: Burma. Retrieved June 18, 2010, from Human Rights Watch: http://www.hrw.org/en/node/87392

Ife, J. (2000, July). Localized Needs and a Globalized Economy: Bridging the Gap with Social Work Practice. Canadian Social Work (Special Issue), pp. 50-64.

International Human Rights Law Clinic at Harvard Law School. (2009). Crimes in Burma. Cambridge, MA: International Human Rights Law Clinic at Harvard Law School.

International Labour Conference, 99th Session. (June 2010). Committee on the Application of Standards: Special sitting to examine developments concerning the question of the observance by the Government of Myanmar of the Forced Labour Convention, 1930 (No. 29). Geneva: International Labour Organization.

Karen Women's Organisation. (February 2007). State of Terror: the ongoing rape, murder, torture and forced labour suffered by women living under the Burmese Military Regime in Karen State. Mae Sot, Thailand: Karen Women's Organisation.

Kelly, L. (2000). Wars Against Women: Sexual Violence, Sexual Politics and the Militarised State. In S. Jacobs, R. Jacobson, \& J. Marchbank (Eds.), States of Conflict: Gender, Violence and Resistance (pp. 45-65). London: Zed Books. 
Lamb, S. (1999). New Versions of Victims: Feminists Struggle with the Concept. New York: New York University Press.

Lawi Weng. (2010, March 6). Junta Should Go Before ICC, Nobel Laureates Tell Ban. Retrieved from The Irrawaddy: http://www.irrawaddy.org/article.php?art_id=17969

Lindsey, C. (2005). The Impact of Armed Conflict on Women. In H. Durham, \& T. Gurd (Eds.), Listening to the Silences: Women and War (pp. 21-35). Leiden, The Netherlands: Martinus Nijhoff Publishers.

Ludlum, S. S. (2010, March 11). Senate Motion - The Situation in Eastern Burma. Retrieved from Senator Scott Ludlum - The Australian Green Party: http://scottludlam.greensmps.org.au/content/situation-eastern-burma

Macan-Markar, M. (2010, February 26). Our Movement is Unique for Women from Burma. Retrieved March 10, 2010, from IPS: http://ipsnews.net/news.asp?idnews=50466

Madill, A., \& Gough, B. (2008). Qualitative Research and Its Place in Psychological Science. Psychological Methods, 13 (3), 254-271.

McClintock, A. (1995). Imperial Leather: Race, Gender and Sexuality in the Colonial Contest. New York and London: Routledge.

McDonald, J. G., Argibay, J. C., Chinkin, J. C., \& Mutunga, J. W. (2001). Judgement on the Common Indictment and the Application for Resitution and Reparation - The Women's International War Crimes Tribunal for the Trial of Japan's Military Sexual Slavery. The Hague: International Organising Committee for the Women's International War Crimes Tribunal.

McRae, R. (2001). Human Security, Connectivity and the New Global Civil Society. In R. McRae, \& D. Hubert (Eds.), Human Security and the New Diplomacy: Protecting People, Promoting Peace (pp. 236-249). Montreal and Kingston: McGill-Queen's University Press and Foreign Affairs and International Trade Canada.

Mehta, V. (1997). Ethnic Conflict and Violence in the Modern World: Social Work's Role in Building Peace. In M. C. Hokenstad, \& J. Midgley (Eds.), Issues in International Social Work: Global Challenges for a New Century. Washington, D.C.: NASW Press.

Minow, M. (1998). Between vengeance and forgiveness: facing history after genocide and mass violence. Boston: Beacon Press.

Mizzima News. (2010, June 10). Commission of inquiry inches closer to realization. Retrieved July 31, 2010, from Mizzima News: http://www.mizzima.com/news/world/4019-commission-ofinquiry-inches-closer-to-realization-.html

Moussa, G. (2008). Gender aspects of human security. In M. Goucha, \& J. Crowley (Eds.), Rethinking Human Security (pp. 81-100). Blackwell Publishing and UNESCO. 
Nichols, M. (2010, March 3). Nobel winners push for Myanmar regime to face court. Retrieved from Reuters: http://www.reuters.com/article/idUSTRE62259P20100303

Nikolic-Ristanovic, V. (2005). Sexual Violence, International Law and Restorative Justice. In D. Buss, \& A. Manji (Eds.), International Law: Modern Feminist Approaches (pp. 273-293). Portland, OR: Hart Publishing.

Nobel Women's Initiative and Women's League of Burma . (2010, March 2). International Tribunal on Crimes Against Women of Burma. New York.

Nobel Women's Initiative. (2009a, August 14). Burma Planning Debrief Meeting. Ottawa, ON, Canada: Internal meeting.

Nobel Women's Initiative. (2010a, March). International Tribunal on Crimes Against Women of Burma: After Action Report. Ottawa, ON: Internal document.

Nobel Women's Initiative. (2010b, March 5). Laureates Meet with UN Secretary-General Ban Kimoon. Retrieved from Nobel Women's Initiative:

http://www.nobelwomensinitiative.org/news/burma/article/laureates-meet-with-un-secretarygeneral-ban-ki-moon

Nobel Women's Initiative. (2008). Women for Peace: Nobel Women's Initiative Delegation to the Thai-Burma border, South Sudan, and the Chadian Border with Darfur. Ottawa, ON.

Nobel Women's Initiative. (2009b). Women Redefining Democracy for Peace, Justice and Equality. Nobel Women's Initiative 2nd International Conference: Women Redefining Democracy. Ottawa, ON: Author.

Pickup, F., Williams, S., \& Sweetman, C. (2001). Ending Violence Against Women: A Challenge for Development and Humanitarian Work. Dorset, UK: Oxfam Great Britain.

Porter, E. (2007). Peacebuilding: Women in international perspective. New York: Routledge.

Posel, D. (2008). History as confession: the case of the South African Truth and Reconciliation Commission. Public Culture, 20 (1), 119-141.

Pugh, M. (2007). Normative values and economic deficits in postconflict transformation. International Journal , 62 (3), 479-493.

Quintana, T. O. (2010). Progress Report of the Special Rapporteur on the situation of human rights in Myanmar. United Nations Human Rights Council, 13th Session.

Reilly, N. (2007). Cosmopolitan feminism and human rights. Hypatia , 22 (4), 180-198.

Rogers, G. (Director). (1994). The Vienna Tribunal: Women's Rights are Human Rights [Motion Picture]. Montréal, Canada.

Rubin, A., \& Babbie, E. R. (2005). Research Methods for Social Workers, 5th Edition. Belmont, CA: Thomson Learning, Inc. 
Sajor, I. L. (1998). Our Common Grounds. In I. L. Sajor (Ed.), Common Grounds: Violence Against Women in War and Armed Conflict Situations (pp. 1-18). Quezon City, Philippines: Asian Center for Women's Human Rights (ASCENT).

Schwartz, K., \& van de Sande, A. (forthcoming). Introduction. In K. Schwartz, \& A. van de Sande, Social Work Research: A Structural Perspective.

Shan Women's Action Network. (2009). SWAN: A ten-year journey. Chiangmai, Thailand: Shan Women's Action Network.

Shaw, C. (2010a, March 9). CSW Reports: March 2, 3, 4 and 5. Retrieved April 5, 2010, from Isis International:

http://www.isiswomen.org/index.php?option=com_content\&view=article\&id=1380:csw-reportsmarch-2-3-4-and-5\&catid=22: movements-within\&Itemid $=229$

Shaw, C. (2010b, March 7). Reflections @ CSW: Where did the week go? Retrieved April 5, 2010, from Pacific Gender Action Portal: http://www.pacificgap.info/2010/03/reflectionscswwhere-did-week-go.html

Shepherd, L. J. (2008). Gender, Violence \& Security: Discourse as Practice. London: Zed Books.

Sundari, E. (2010, April 21). Sanctions will force Burmese junta to negotiate. Retrieved May 12, 2010, from Sydney Morning Herald: http://www.smh.com.au/opinion/politics/sanctions-willforce-burmese-junta-to-negotiate-20100421-suj0.html

Teitel, R. (2000). Criminal justice. In R. Teitel, Transitional justice (pp. 27-67). Oxford: Oxford University Press.

The Paley Center for Media. (2010, August). Burma and the Media: Amplifying Voices for Democracy. Retrieved August 13, 2010, from The Paley Center for Media:

http://www.paleycenter.org/2010-burma-and-the-media-the-building-of-a-democracy-movement

The Pixel Project. (2010, April 3). The Pixel Project's Violence Against Women e-News Digest Edition Eight. Retrieved April 6, 2010, from The Pixel Project:

http://www.thepixelproject.net/2010/04/03/the-pixel-project\%E2\%80\%99s-violence-againstwomen-e-news-digest-edition-eight/

Torczyner, J. (2000, July). Globalization, Inequality and Peace Building: What Social Work Can Do. Canadian Social Work (Special Issue), pp. 123-146.

United Nations. (1993a, December 20). Declaration on the Elimination of Violence Against Women. Retrieved December 1, 2009, from United Nations:

http://www.unhchr.ch/huridocda/huridoca.nsf/(symbol)/a.res.48.104.en

United Nations Security Council. (20 August 2009). Report of the Secretary-General pursuant to Security Council resolution 1820 (2008). New York: United Nations. 
United Nations. (1993b, June 25). Vienna Declaration and Programme of Action. Retrieved December 1, 2009, from United Nations:

http://www.unhchr.ch/huridocda/huridoca.nsf/(symbol)/a.conf.157.23.en

Unrepresented Nations and Peoples Organization. (2010, March 8). International Women's Day: Women Fighting for Democracy in Burma. Retrieved March 30, 2010, from Unrepresented Nations and Peoples Organization: http://www.unpo.org/article/10821

US Campaign for Burma. (2010). Countries Supporting a UN-led Commission of Inquiry on Burma. Retrieved July 31, 2010, from US Campaign for Burma:

http://uscampaignforburma.org/countries-supporting-commission-of-inquiry-on-burma

Violence Against Women in War Network - Japan. (n.d.). Participants. Retrieved November 24, 2009, from Women's Tribunal 2000: http://www1.jca.apc.org/vaww-netjapan/english/womenstribunal2000/participants_japanese.html

White, A. M. (2007). All the men are fighting for freedom, all the women are mourning their men, but some of us carried guns: A raced-gendered analysis of Fanon's psychological perspectives on war. Signs , 32 (4), 857-884.

Women's League of Burma. (November 2007). Courage to Resist: Women Human Rights Defenders of Burma. Chiang Mai, Thailand: Women's League of Burma.

Women's League of Burma. (2010, June 27). Peoples' Tribunal on the Crimes against Women of Burma (Japan). Retrieved August 9, 2010, from Women's League of Burma: http://www.womenofburma.org/

Yegidis, B. L., Weinbach, R. W., \& Morrison-Rodriguez, B. (1999). Research Methods for Social Workers, 3rd Edition. Needham Heights, MA: Allyn and Bacon.

Yin, R. K. (2009). Case Study Research: Design and Methods, 4th Edition. Thousand Oaks, CA: Sage Publications, Inc.

Zaccaro, S. (2010, March 8). Burmese Rape Survivors Speak Out. Retrieved from IPS/TerraViva: http://ipsnews.net/news.asp?idnews $=50588$ 


\title{
APPENDIX I: Online Representation of the International Tribunal on Crimes Against Women of Burma
}

\author{
NEWS MEDIA
}

\section{PRINT}

Ebadi, Shirin and Jody Williams, (28 June 2010), "Dispatch Online: Burma poll will entrench brutality", Burma News Net, Available online at:

http://www.burmanet.org/news/2010/06/28/dispatch-online-burma-poll-will-entrenchbrutality-shirin-ebadi-and-jody-williams/

Farrelly, Nicholas, (1 March 2010), "International Tribunal on Crimes Against Women of Burma", The New Mandela, Available online at:

http://asiapacific.anu.edu.au/newmandala/2010/03/01/international-tribunal-on-crimesagainst-women-of-burma/

Free Burma Coalition - Philippines Women, (9 March 2010), "End all forms of violence against women in Burma!", The New York City Independent Media Center, Available online at: http://nyc.indymedia.org/en/2010/03/109917.html

Henander, Brandon, (17 March 2010), "International Burma Tribunal Releases Judgment Regarding War Crimes and Crimes Against Humanity", Foreign Policy Association, Available online at: http://warcrimes.foreignpolicyblogs.com/2010/03/17/iniernationalburma-tribunal-releases-judgment-regarding-war-crimes-and-crimes-against-humanity/

- Also appeared in: Burma Digest, 18 March 2010, Available online at: http://burmadigest.info/2010/03/18/burma-related-news-march-18-2010/

"International Tribunal on Crimes Against Women of Burma - March 2, NY", (26 February 2010), IPS, Available online at: http://www.ips.org/mdg3/international-tribunalon-crimes-against-women-of-burma- $\%$ E2\%80\%93-march-2-ny/

- Also appeared in: "International Tribunal on Crimes Against Women of Burma", World Pulse, 2 March 2010, Available online at: http://www.worldpulse.com/pulsewire/exchange/events/17976 
"International Tribunal on Crimes Against Women of Burma, Report Available", (26 May 2010), IPS, Available online at: http://www.ips.org/mdg3/report-for-theinternational-tribunal-on-crimes-against-women-of-burma-released/

"It's Taken Root in My Heart", (March 2010), Exclusive Living, Available online at: http://exclusiveliving.exclusiveresorts.com/content/2010_March_Members_Speak

"Invitation: International Tribunal on Crimes Against Women of Burma", (8 February 2010), Burma Digest, Available online at: http://burmadigest.info/2010/02/08/invitationinternational-tribunal-on-crimes-against-women-of-burma/

"Invitation to the International Tribunal on Crimes Against Women of Burma", (24 February 2010), Burma Digest, Available online at:

http://burmadigest.info/2010/02/24/invitation-to-the-international-tribunal-on-crimesagainst-women-of-burma/

Kafcaloudes, Phil, (3 March 2010), "Burma War Atrocities: Women Speak Up", Radio Australia Today Editorial, Available online at:

http://blogs.radioaustralia.net.au/today/burma-war-atrocities-women-speak-up

Lawi Weng, (6 March 2010), "Junta Should Go Before ICC, Nobel Laureates Tell Ban", The Irrawaddy, Available online at: http://www.irrawaddy.org/article.php?art id=17969

- Also appeared in: Asia Pacific Solidarity Network, 6 March 2010, Available online at: http://asia-pacificsolidarity.net/southeastasia/burma/news2010/ irrawaddy_burmesejuntashouldgobefor_060310.htm

Also appeared in: Indymedia-Letzebuerg, 7 March 2010, Available online at:

http://www.indymedialetzebuerg.net/index.php?option $=$ com_content\&task $=$ view \&id $=45145 \&$ Itemid $=28$

"L'histoire des femmes Birmanes", (4 March 2010), Au Feminin, Available online at: http://blog.aufeminin.com/blog/see_442707_2/En-direct-de-New-York 
Lipes, Joshua and Ingjing Naing, (8 March 2010), “Tribunal calls for Criminal Court”, Radio Free Asia, Available online at: http://www.rfa.org/english/news/burma/violationsagainst-women-03082010162007.html

- Also appeared in: UN Refugee Agency (UNHCR) - Refworld, 8 March 2010, Available online at: http://www.unhcr.org/refworld/docid/4bab813117.html

- Also appeared in: Uyghur News, 8 March 2010, Available online at: http://www.uyghurnews.com/radiofreeasia/Read.asp?RadioFreeAsia=tribu $\underline{\text { nal-calls-for-criminal-court\&ItemID }=Y M-3122010114741010195661}$

Macan-Markar, Marwaan with Hseng Noung, (26 February 2010), "Our Movement is Unique for Women from Burma", IPS, Available online at: http://ipsnews.net/news.asp?idnews $=50466$

- Also appeared in: "Our Movement is Unique for Women", The Irrawaddy, 26 February 2010, Available online at: http://www.irrawaddy.org/article.php?art id=17899\&page=1

"Mock Tribunal to Highlight Crimes against Women in Burma", (8 February 2010), Chinland Guardian, Available online at: http://www.chinlandguardian.com/news2009/896-mock-tribunal-to-highlight-crimes-against-women-in-burma.html

Mungpi, (4 March 2010), "Burmese junta must be referred to ICC: Nobel Laureates", Mizzima, Available online at: http://www.mizzima.com/news/world/3605-junta-must-bereferred-to-icc-nobel-laureates-.html

Nan Kham Kaew, "Burmese women testify at the UN", (5 March 2010), Democratic Voice of Burma, Available online at: http://www.dvb.no/news/burmese-women-testify-atthe-un/7275

Nichols, Michelle, "Nobel winners push for Myanmar regime to face court", (3 March 2010), Reuters, Available online at:

http://www.reuters.com/article/idUSTRE62259P20100303

- Also appeared in: Reuters AlertNet, 3 March 2010, Previously available online at: http://www.alertnet.org/thenews/newsdesk/N0393436.htm 
- Also appeared in: Washington Post, 3 March 2010, Previously available online at:

http://www.washingtonpost.com/wp-dyn/content/article/2010/03/03/AR2 $\underline{010030302973 . \mathrm{html}}$

- Also appeared in: New York Times, 3 March 2010, Previously available online at:

http://www.nytimes.com/reuters/2010/03/03/world/international-usmyanmar-crimes.html? $\mathrm{r}=3 \& \mathrm{scp}=6 \& \mathrm{sq}=$ burma\&st $=\mathrm{cse}$

- Also appeared in: News Daily, 3 March 2010, Previously available online at: http://www.newsdaily.com/

- Also appeared in: Taungzalat News, 3 March 2010, Available online at: http://taungzalatnews.blogspot.com/2010/03/nobel-winners-push-formyanmar-regime.html

- Also appeared in: Radio Television Brunei, 4 March 2010, Available

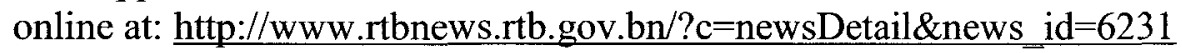

- Also appeared in: The Star Online, 4 March 2010, Available online at: http://thestar.com.my/news/story.asp?file=/2010/3/4/worldupdates $/ 2010$ 03-04T030822Z 01 NOOTR_RTRMDNC 0 _-466354$1 \& \mathrm{sec}=$ Worldupdates

- Also appeared in: The Morung Express, 4 March 2010, Available online at: http://www.morungexpress.com/international/44533.html

- Also appeared in: Burma Net News, 4 March 2010, Available online at: http://www.burma-network.com/index.php?option=com_wrapper\&Itemid=47

- Also appeared in: VietNam Daily News, Previously available online at: http://dailynews.vn/news/vietnam-society/vietnamsociety/38020-Nobelwinners-push-for-Burma-regime-to-face-courthtml

- Also appeared in: intellasia.net, 5 March 2010, Available online at: http://dailynews.vn/frame/index.php?url=aHR0cDovL3d3dy5pbnRlbGxhc 2lhLm5ldC9uZXdzL2FydGlibGVzL3NvY2lldHkvMTExMjg4NDQzLnN odGls

"Pressing HR charges against Myanmar a dream", (5 March 2010), The News

International, Previously available online at:

http://www.thenews.com.pk/daily_detail.asp?id=227353 
Roughneen, Simon, (3 March 2010), "Nobel Laureates Urge Inquiry into Junta Crimes", The Irrawaddy, Available online at: http://www.irrawaddy.org/article.php?art id=17937

- Also appeared in: Worldpress.org, 5 March 2010, Available online at: http://www.worldpress.org/Asia/3509.cfm

- Also appeared in: Network for Human Rights Documentation - Burma, Available online at: http://www.nd-burma.org/news/41-top-headlines/236nobel-laureates-urge-inquiry-into-junta-crimes-.html? fontstyle=f-larger

Roughneen, Simon, (11 March 2010), "Quintana Recommends UN War Crimes Commission on Burma", The Irrawaddy, Available online at: http://www.irrawaddy.org/article.php?art id=18013

Stokes, Emily, (5 March 2010), "This is my witness", OpenDemocracy, Available online at: http://www.opendemocracy.net/5050/emily-stokes/this-is-my-witness

- Also appeared in: "Burma Women's Tribunal Testimony", World Pulse, 13 March 2010, Available online: http://www.worldpulse.com/node/18627

- Also appeared in: The Morung Express, Available online at: http://www.morungexpress.com/analysis/44772.html

- Also appeared in: India Times, March 2010, Available online at: http://iplextra.indiatimes.com/article/0h0jbTpeoAeYk?q=Iran

Sundari, Eva, (21 April 2010), "Sanctions will force Burmese junta to negotiate", Sydney Morning Herald, Available online at: http://www.smh.com.au/opinion/politics/sanctionswill-force-burmese-junta-to-negotiate-20100421-suj0.html

- Also appeared in: The Age, 21 April 2010, Available online at: http://www.theage.com.au/opinion/politics/sanctions-will-force-burmesejunta-to-negotiate-20100421-suj0.html

- Also appeared in: ASEAN Inter-Parliamentary Myanmar Caucus, 22 April 2010, Available online at: http://www.aseanmp.org/?p=2483

Terzieff, Juliette, (5 March 2010), "Nobel Women Push for ICC Myanmar Changes", World Politics Review, Available online at: http://www.worldpoliticsreview.com/trendlines/5227/nobel-women-push-for-icc-myanmar-charges 
- Also appeared in: India Times, March 2010, Available online at: http://iplextra.indiatimes.com/article/08FifVAloDfjg?q=Iran

"The Nobel Women's Initiative: Amplifying the Voice of Women in Burma", (22 October 2009), IPS, Available online at: http://www.ips.org/mdg3/the-nobelwomen $\% \mathrm{E} 2 \% 80 \% 99$ s-initiative-amplifying-the-voice-of-women-in-burma/

Turnbull, Lucy, (8 March 2010), "UN must step up for the women of Burma", Sydney Morning Herald, Available online at: http://www.smh.com.au/opinion/politics/un-muststep-up-for-the-women-of-burma-20100307-pqhv.html

- Also appeared in: Burma Net News, 8 March 2010, Available online at: http://www.burma-network.com/index.php?option=com_wrapper\&Itemid $=47$

Weiss, Cora, (4 March 2010), "Burma may save its tigers and not its women", OpenDemocracy, Available online at: http://www.opendemocracy.net/5050/coraweiss/burma-may-save-its-tigers-and-not-its-women

- Also appeared in: Democracy for Burma, 4 March 2010, Available online at: http://democracyforburma.wordpress.com/2010/03/04/burma-maysave-its-tigers-and-not-its-women-by-open-democracy/

- Also appeared in: Global Sisterhood Network, 4 March 2010, Available online at: http://www.global-sisterhoodnetwork.org/content/view/2418/59/

- Also appeared in: India Times, March 2010, Available online at: http://iplextra.indiatimes.com/article/05H17h42tSd4z?q=Iran

"What We're Watching: The International Tribunal on Crimes Against Women of Burma Report", (25 May 2010), World Pulse, Available online at:

http://www.worldpulse.com/about/blog/what-we-re-watching-the-international-tribunalon-crimes-against-women-of-burma-

Williams, Jody, (17 June 2010), "Women in Burma will not be silenced", World Pulse, Available online at: http://www.worldpulse.com/magazine/columns/visionaryleaders/women-in-burma-will-not-be-silenced 
Zaccaro, Sabina, (8 March 2010), "Burmese Rape Survivors Speak Out", IPS/TerraViva, Available online at: http://ipsnews.net/news.asp?idnews $=50588$

- Also appeared in: The Irrawaddy, 9 March 2010, Available online at: http://www.irrawaddy.org/article.php?art id=17989

- Also appeared in: TerraViva Beijing +15, 7 March 2010, Available online at: http://www.ips.org/TV/beijing15/burmese-rape-victims-speak-out/

- Also appeared in: Network for Human Rights Documentation - Burma, Available online at: http://www.nd-burma.org/news/41-top-headlines/237burmese-rape-survivors-speak-out-html

\section{RADIO}

Lam, Sen, "Australian companies urged to stop investing in Burma", (10 March 2010), Radio Australia - Connect Asia, Podcast available online at: http://www.radioaustralia.net.au/connectasia/stories/201003/s2841621.htm

Lam, Sen, "International court calls for more action to help Burmese women", (4 March 2010), Radio Australia - Connect Asia, Podcast available online at: http://www.radioaustralia.net.au/connectasia/stories/201003/s2836226.htm

- Also appeared in: India Times (March 2010), Available online at: http://iplextra.indiatimes.com/article/0gHTbXVbP5bMn?q=Iran

\section{SOCIAL MEDIA}

\section{FACEBOOK}

Aung San Suu Kyi: http://www.facebook.com/aungsansuukyi

Burma Campaign Australia: http://www.facebook.com/pages/Burma-CampaignAustralia/256066414355

Burma VJ (Norway): http://ko-kr.connect.facebook.com/burmamovie?filter=2

Ellen Morgan: http://www.facebook.com/people/Ellen-Morgan/622165580

Erin Simpson: http://www.facebook.com/people/Erin-Simpson/711255704 
International Tribunal on Crimes Against Women of Burma - Event Page:

http://www.facebook.com/event.php?eid $=346932466656$ \&index $=1$

Jody Williams:

http://www.facebook.com/nobelwomen\#!/profile.php?id=1806316930\&ref=ts

Kieran Bergmann: http://www.facebook.com/people/Kieran-Bergmann/81012004

Kim Mackenzie: http://www.facebook.com/people/Kim-MacKenzie/518776544

Liz Bernstein: http://www.facebook.com/people/Liz-Bernstein/592897100

Nadia Kalinchuk: http://www.facebook.com/nadia.kalinchuk

Nobel Women's Initiative : $\underline{\text { http://www.facebook.com/pages/Nobel-Womens- }}$ $\underline{\text { Initiative/95360261736 }}$

Shirin Ebadi:

http://www.facebook.com/group.php?gid=2223818300\#!/group.php?gid=2223818300\&v

$=$ wall

Support the Monks' Protest in Burma (Burma Global Action Network): http://www.facebook.com/BurmaGlobalActionNetwork

US Campaign for Burma: http://www.facebook.com/pages/US-Campaign-forBurma/115691890947

\section{TWITTER}

www.twitter.com/AllysonNeville

www.twitter.com/bgan

$\underline{\text { www.twitter.com/BPWAustralia }}$

www.twitter.com/BurmaCampaignA

$\underline{\mathrm{U}}$

$\underline{\text { www.twitter.com/Burmakomite }}$

www.twitter.com/burmapartners

www.twitter.com/catchmaite
www.twitter.com/CdnJoops

www.twitter.com/civicresistance

www.twitter.com/CrookdRiverWmn

www.twitter.com/Dion_JesusGirl

www.twitter.com/eco4life

www.twitter.com/emilywgoose

www.twitter.com/Fempeace

www.twitter.com/GlobalFundWomen 


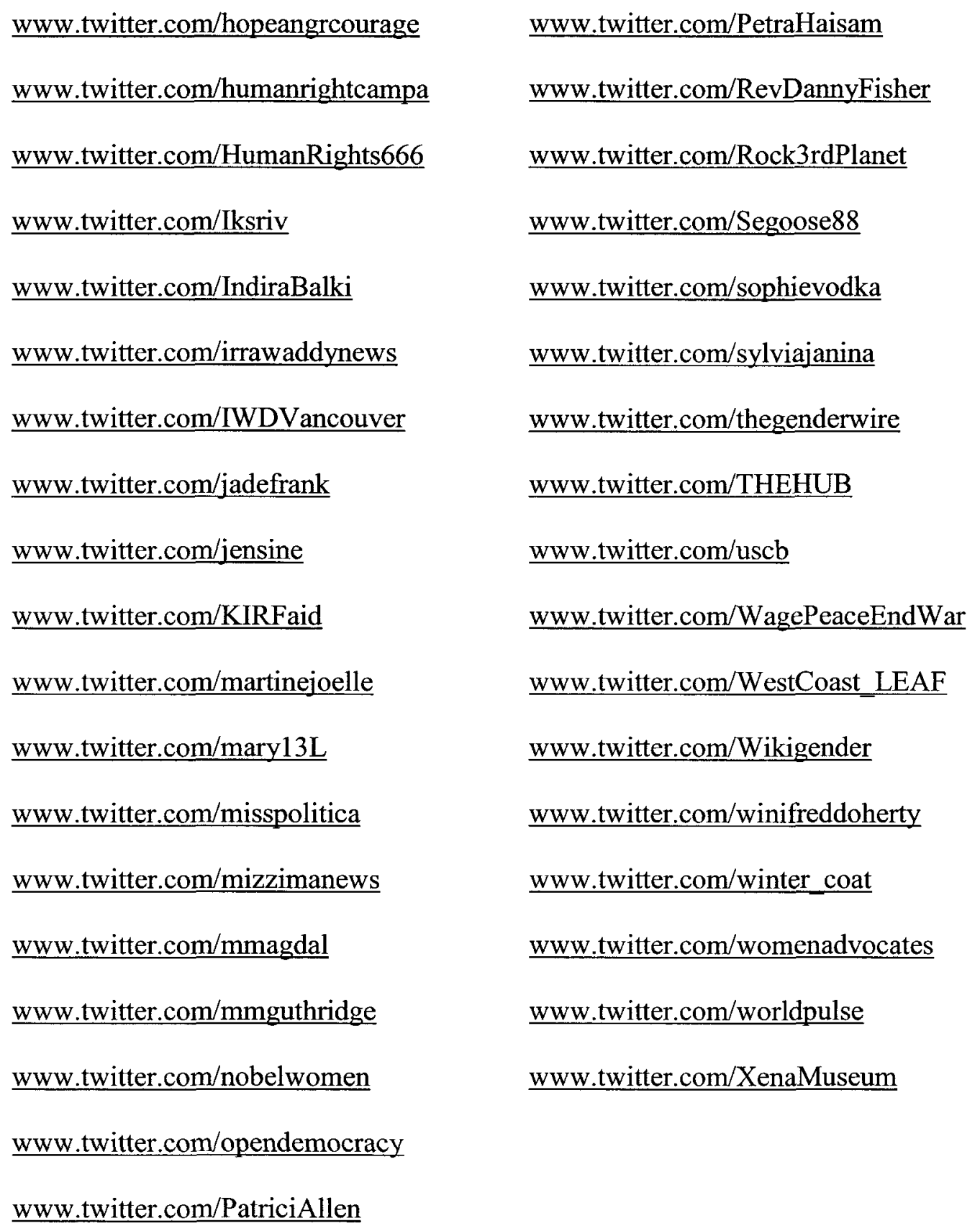

\section{YOUTUBE}

"Crimes Against Women in Burma", Voice of America Burmese News, 5 March 2010

Available online at: http://www.youtube.com/watch?v=xtidTK196a0, 1915 views

"Crimes Against Women of Burma", Voice of America English News, 9 March 2010 
Available online at: $h \mathrm{http}: / / \mathrm{www}$.youtube.com/watch?v=vMUlt hDbbU, 62 views "International Tribunal on Crimes Against Women of Burma", Nobel Women's Initiative, 12 March 2010, Available online at:

http://www.youtube.com/watch?v= rpSIGOHHDg, 155 views

"Mia Farrow on the Women of Burma", Nobel Women's Initiative, 22 February 2010, Available online at: http://www.youtube.com/watch?v=oTMKtkiBt o, 1021 views

"Stories of the Women of Burma: Saw Speaks About Courage", Nobel Women's Initiative, 3 March 2010, Available online at: http://www.youtube.com/watch?v=iNyY5m0PNI, 2145 views

“The International Tribunal (English)", Voice of America, 8 March 2010, Available online at: http://www.youtube.com/watch?v=4EeWGpsajYA, 327 views

"TV Magazine Program - March $2^{\text {nd }}$ Week (Part 1)", Voice of America Burmese News, 5 March 2010, Available online at:

http://www.youtube.com/watch?v=rp NtWHoJm8\& feature=related, 2602 views

\section{CIVIL SOCIETY ORGANIZATION SITES AND COMMUNICATIONS}

8888 Faces to Free Daw Aung San Suu Kyi, (8 March 2010), "End all forms of violence against women in Burma!', Available online at:

http://www.8888faces.org/index.php?option=com content\&task=view\&id=45\&Itemid=2

Alternative ASEAN Network on Burma, (March 2010), "Human Rights - Ojea Quintana calls for criminal accountability", Burma Bulletin, Issue 39, Available online at:

http://www.altsean.org/Docs/PDF\%20Format/Burma\%20Bulletin/March\%202010\%20B urma\%20Bulletin.pdf

American University Student Campaign for Burma, (24 February 2010), "The Burma News Café!", Available online at: http://auburma.blogspot.com/2010/02/burma-newscafe.html 
Association for Women's Rights in Development (AWID), (2010), "Int'l Tribunal on Crimes Against Women in Burma", Available online at: http://www.awid.org/eng/Issuesand-Analysis/Library/Int-1-Tribunal

- (3 March 2010), “A New Resource: Nobel Women's Initiative: International Tribunal on Crimes Against Women of Burma”, Available online at: http://www.awid.org/eng/Issues-and-Analysis/Library/A-NewResource-Nobel-Women-s-Initiative-International-Tribunal-on-CrimesAgainst-Women-of-Burma

- (19 May 2010), “A New Resource: Nobel Women's Initiative: Report of the International Tribunal on Crimes Against Women of Burma", Available online at: http://www.awid.org/eng/Issues-andAnalysis/Library/A-New-Resource-Nobel-Women-s-Initiative-Report-ofthe-International-Tribunal-on-Crimes-Against-Women-of-Burma

Burma Campaign Australia, (2010), "Home Page", linked to media release about Tribunal, Previously available online at: http://www.aucampaignforburma.org/

- (4 March 2010), "BCA Media Release: International Tribunal: Avoid Burma's oil and gas industry - it uses slave labour", Available online at: http://www.aucampaignforburma.org/BCANews.htm

Burma Global Action Network, (1 March 2010), "Nobel Women's Initiative: Nobel laureates to host international tribunal on crimes against women of Burma", Available online at: http://www.burma-network.com/index.php?option=com wrapper\&Itemid $=47$

Burma Partnership, (3 March 2010), "International Tribunal on Burma Calls for End to Impunity of Military Regime", Available online at:

http://www.burmapartnership.org/2010/03/international-tribunal-on-burma-calls-for-endto-impunity-of-military-regime/

- (27 February 2010), "International Tribunal on Crimes Against Women of Burma - March $2^{\text {nd }}, 2010 "$, Available online at:

http://www.burmapartnership.org/2010/02/international-tribunal-oncrimes-against-women-of-burma-march-2nd-2010/

- (14 May 2010), "Report on the International Tribunal on Crimes Against Women of Burma", Available online at: http://www.burmapartnership.org/2010/05/report-on-the-internationaltribunal-on-crimes-against-women-of-burma/ 
- "Campaigns: Crimes Against Humanity", links to Tribunal report and to Nobel Women's Initiative and Women's League of Burma websites, Available online at: http://www.burmapartnership.org/campaigns/crimesagainst-humanity!

Burmese Voice from Bay Area, "Invitation: International Tribunal on Crimes Against Women of Burma", Available online at:

http://www.baymyanmar.com/2010/02/invitation-international-tribunal-on.html

Center for Women's Global Leadership, (2010), "Beijing $+15-54^{\text {th }}$ Session of the Commission on the Status of Women - March 1-12, 2010: CWGL Co-Sponsored Events", Available online at:

http://www.cwgl.rutgers.edu/globalcenter/policy/b15/index.html

Eastern Oregon University, (19 March 2010), "Student learns art of advocacy at United Nations", Available online at: http://www.eou.edu/ua/news/hill un.html

Feminist Law Professors, (March 2010), "Video Stream - International Tribunal on Crimes Against Women of Burma", Available online at:

http://feministlawprofessors.com/?p=15205

Global Fund for Women, (Spring 2010 Newsletter), "Looking Back, Moving Forward: Reflections on the $54^{\text {th }}$ Session of CSW and Beijing +15", Available online at: http://www.globalfundforwomen.org/what-we-do/publications/newsletters/spring-2010/1658looking-back-moving-forward-reflections-on-the-54th-session-of-csw-and-beijing 15

- (26 May 2010), "New Report on International Tribunal on Crimes Against Women of Burma", Available online at: http://www.globalfundforwomen.org/what-we-do/the-issues/analysis/1679-newreport-on-international-tribunal-on-crimes-against-women-of-burma

Global Justice Center, "International Tribunal on Crimes Against Women of Burma", Available online at: http://globaljusticecenter.net/news-events/events/2010/internationaltribunal-burma-nwi.html

- (5 May 2010), "GJC News at the UN", Available online at: http://www.globaljusticecenter.net/news-events/news/2010/GJC-CSWenews-5.5.10.html 
International Coalition for the Responsibility to Protect, (24 February 2010), "Listserv Related Events", Available online at:

http://www.responsibilitytoprotect.org/index.php/component/content/article/136-latestnews/2718-crimes-against-humanity-in-guinea-conference-on-rtop-and-civilianprotection-in-cameroon

International Women's Development Agency, Inc., (23 February 2010), "WLB to give testimonials at International Tribunal on Crimes Against Women of Burma", Available online at: http://www.iwda.org.au/au/2010/02/23/wlb-to-give-testimonials-atinternational-tribunal-on-crimes-against-women-of-burma/

- (3 June 2010), "Nobel Women's Initiative: Report of the International Tribunal on Crimes Against Women", Available online at: http://www.iwda.org.au/au/2010/06/03/nobel-womens-initiative-report-ofthe-international-tribunal-on-crimes-against-women-of-burma/

Isis International, (9 March 2010), "CSW Reports: March 2, 3, 4 and 5", Available online at:

http://www.isiswomen.org/index.php?option=com_content \&view $=$ article\&id $=1380: \mathrm{csw}$ reports-march-2-3-4-and-5\&catid=22: movements-within\&Itemid=229

Karen People in Ottawa, (2 March 2010), "International Tribunal on Crimes Against Women of Burma", Available online at:

http://karenottawa.blogspot.com/2010/03/international-tribunal-on-crimes.html

- (3 March 2010), "Press Release From International Tribunal on Crimes Against Women of Burma", Available online at: http://karenottawa.blogspot.com/2010/03/international-tribunal-oncrimes 03.html

Koskie Minsky LLP, (17 May 2010), "KM Sponsors the International Tribunal on Crimes Against Women of Burma", Available online at:

http://www.koskieminsky.com/About-Us/News/News-Item/?list=News\&rid=55

MADRE, (2 March 2010), "International Tribunal on Crimes Committed Against Women in Burma", Available online at:

http://madreblogs.typepad.com/mymadre/2010/03/-international-tribunal-on-crimescommitted-against-women-in-burma.html 
Nobel Women's Initiative, (12 February 2010), "International Tribunal on Crimes Against Women of Burma", Available online at:

http://www.nobelwomensinitiative.org/news/event-news/article/international-tribunal-oncrimes-against-women-of-burma\#system-readmore

- (25 February 2010), "Mia Farrow Highlights Upcoming Burma Tribunal", Available online at:

http://www.nobelwomensinitiative.org/news/burma/article/mia-farrowhighlights-upcoming-burma-tribunal\#system-readmore

- (25 February 2010), "International Tribunal on Crimes Against Women of Burma - March $2^{\text {nd }} 2010$ ", Available online at:

http://www.nobelwomensinitiative.org/news/burma/article/burma-tribunal

- (25 February 2010), "Burma Tribunal Blog: Mia Farrow on the Women of Burma", Available online at:

http://www.nobelwomensinitiative.org/blogs/burmatribunal/post/miafarrow

- (25 February 2010), "Burma Tribunal Blog: Stories of the Women of Burma - Day 1", Available online at:

http://www.nobelwomensinitiative.org/blogs/burmatribunal/post/learnmore-about-our-first-testifiers-story

- (26 February 2010), "Burma Tribunal Blog: Stories of the Women of Burma - Day 2", Available online at:

http://www.nobelwomensinitiative.org/blogs/burmatribunal/post/storiesof-the-women-of-burma-day-2-

- (28 February 2010), "Burma Tribunal Blog: Stories of the Women of Burma - Day 3", Available online at:

http://www.nobelwomensinitiative.org/blogs/burmatribunal/post/storiesof-the-women-of-burma-day-3

- (1 March 2010), "Burma Tribunal Blog: Stories of the Women of Burma Day 4", Available online at:

http://www.nobelwomensinitiative.org/blogs/burmatribunal/post/storiesof-the-women-of-burma-day-4

- (2 March 2010), "International Tribunal on Crimes Against Women of Burma - Live Webcast", Archived and available online at: http://www.nobelwomensinitiative.org/blogs/burmatribunal/webcast 
- (2 March 2010), "Burma Tribunal Blog: Anticipation", Available online at:

http://www.nobelwomensinitiative.org/blogs/burmatribunal/post/tribunala nticipation

- (2 March 2010), "Burma Tribunal Blog: Tortures of Shame and Silence Reflections on the first session of testimony", Available online at: http://www.nobelwomensinitiative.org/blogs/burmatribunal/post/torturesof-shame-and-silence

- (2 March 2010), "Burma Tribunal Blog: 'It broke my heart, once and for all' - Reflections on the second session of testimony", Available online at: http://www.nobelwomensinitiative.org/blogs/burmatribunal/post/it-brokemy-heart-once-and-for-all

- (2 March 2010), "Burma Tribunal Blog: Common, but not normal Reflections on the third session of testimony", Available online at: http://www.nobelwomensinitiative.org/blogs/burmatribunal/post/commonbut-not-normal

- (3 March 2010), "Burma Tribunal Blog: Stories of the Women of Burma Courage", Available online at:

http://www.nobelwomensinitiative.org/blogs/burmatribunal/post/storiesof-the-women-of-burma-courage

- (4 March 2010), "Burma Tribunal Blog: The World is Watching-Media Coverage of Tribunal", Available online at:

http://www.nobelwomensinitiative.org/blogs/burmatribunal/post/theworld-is-watching

- (5 March, 2010), "Laureates Meet with UN Secretary-General Ban Kimoon", Available online at:

http://www.nobelwomensinitiative.org/news/burma/article/laureates-meetwith-un-secretary-general-ban-ki-moon\#system-readmore

- (12 May 2010), "Burma Tribunal Blog: Video - Watch the Tribunal Unfold", Available online at:

http://www.nobelwomensinitiative.org/blogs/burmatribunal/post/videowatch-the-tribunal-unfold

- (13 May 2010), "Now Available: Report of the International Tribunal on Crimes Against Women of Burma", Available online at: http://www.nobelwomensinitiative.org/news/burma/article/now-availablereport-of-the-international-tribunal-on-crimes-against-women-ofburma\#system-readmore 
- (18 May 2010), "Burma Tribunal Blog: Report - International Tribunal on Crimes Against Women of Burma", Available online at:

http://www.nobelwomensinitiative.org/blogs/burmatribunal/post/report

- (2010), "International Tribunal on Crimes Against Women of Burma Photo Gallery", Available online at:

http://www.nobelwomensinitiative.org/blogs/burmatribunal/burmatribunal-gallery

- (26 February 2010), "International Tribunal on Crimes Against Women of Burma: Follow us Virtually!", Email to supporters inviting them to watch the Tribunal in person or via webcast and linking them to other social media portals

- (2 March 2010), "International Tribunal on Crimes Against Women of Burma: Follow us Virtually!", Reminder email to supporters inviting them to watch the Tribunal in person or via webcast and linking them to other social media portals

- (1 April 2010), "Nobel Women's Initiative Update - March 2010", Enewsletter to supporters providing brief summary of Tribunal, linking supporters to further information about the Tribunal, and reminding them to look for the full report in future

- (18 May 2010), "Now Available: Burma Tribunal Report", Email to supporters linking them to the electronic version of the Tribunal Report, as well as other related links

Online Burma/Myanmar Library, (28 February 2010), "International Tribunal on Crimes Against Women in Burma - March 2, 2010", Available online at: http://www.burmalibrary.org/show.php?cat $=642 \& l o=\& s l=1$

Pacific Gender Action Portal, (7 March 2010), "Reflections @ CSW: Where did the week go?", Available online at: $\underline{\text { http://www.pacificgap.info/2010/03/reflectionscsw-where-did- }}$ week-go.html

Partners Relief and Development, (10 March 2010), "International Tribunal on Burma Calls for an End to Violence against Women", Available online at: http://blog.partnersworld.org/? $\mathrm{p}=521$ 
Peace Women Across the Globe, (18 May 2010), "Report on the International Tribunal on Crimes Against Women of Burma", Available online at:

http://www.1000peacewomen.org/eng/aktuell news detail.php?IDNews=186

Rev. Danny Fisher, (3 March), "International Tribunal on Burma Calls for End to Impunity of Military Regime", Available online at:

http://dannyfisher.org/2010/03/03/international-tribunal-on-burma-calls-for-end-toimpunity-of-military-regime/

Rights and Democracy, (26 May 2010), "Launch of the Report of the International Tribunal on Crimes Against Women of Burma", Available online at: http://ddrd.net/cms/site/node/863

South Asia Citizens Web, (6 March 2010), "Press Release From International Tribunal on Crimes Against Women of Burma", Available online at: http://www.sacw.net/article1368.html

The Pixel Project, (3 April 2010), "The Pixel Project's Violence Against Women e-News Digest Edition Eight", Available online at: http://www.thepixelproject.net/2010/04/03/the-pixel-project $\% \mathrm{E} 2 \% 80 \% 99$ s-violenceagainst-women-e-news-digest-edition-eight//

Threat to the Peace - Support the Call for UN Security Council Action on Burma!, (2010), "Criminal Accountability: Updates", Available online at:

http://www.unscburma.org/Crimes $\% 20 \mathrm{in} \% 20$ Burma/ICC/Updates.php?Submit=Updates

Unrepresented Nations and Peoples Organization, (8 March 2010), "International Women's Day: Women Fighting for Democracy in Burma", Available online at: http://www.unpo.org/article/10821

US Campaign for Burma, (2 March 2010), "International Tribunal on Crimes Against Women in Burma takes place today - watch live", Available online at http://doiyeh.wordpress.com/2010/03/02/

- (25 February 2010), "Historic Event Spotlights Crimes in Burma", Email to supporters inviting them to watch the Tribunal in person or via webcast 
- (4 March 2010), "International Tribunal on Crimes Against Women in Burma - Part 2", Available online at: http://doiyeh.wordpress.com/2010/03/04/international-tribunal-on-crimesagainst-women-of-burma-part-2/

- (25 March 2010), "Arrest Yourself for Aung San Suu Kyi and Burma", Email to supporters citing the Tribunal and its judgment, and asking supporters to build on this momentum by taking part in a different advocacy effort

- "Crimes Against Humanity in Burma", page dedicated to information regarding crimes in Burma, links to dedicated Tribunal page, Available online at: http://uscampaignforburma.org/crimesagainsthumanityinburma

- "International Tribunal on Crimes Against Women of Burma", page dedicated to the Tribunal and its findings, Available online at: http://uscampaignforburma.org/international-tribunal-on-crimes-againstwomen-in-burma

- "US Campaign for Burma Home Page", has link to "Crimes Against Humanity in Burma" page, Available online at: http://uscampaignforburma.org/

Women's International League for Peace and Freedom, (2010), "Home Page", Linked to Tribunal report, Previously available online at: http://www.peacewomen.org/

- (18 May 2010), "Burma: Report of the International Tribunal on Crimes Against Women of Burma (NGO)", Available online at: http://www.peacewomen.org/portal_resources_resource.php?id=525

- (26 May 2010), "Burma: International Tribunal on Crimes Against Women in Burma, Report Available", Available online at: http://www.peacewomen.org/news article.php?id=845\&type=news

Women's League of Burma, (2010), "Home Page", links to Tribunal report and to more information about the Tribunal on the Nobel Women's Initiative website, Available online at: http://www.womenofburma.org/

World Centers of Compassion for Children International, (28 February 2010), "International Tribunal on Crimes Against Women of Burma", Available online at: http://wccci.org/news-and-events/?p=272 
Zunia Knowledge Exchange, (15 June 2010), "New Report on the International Tribunal on Crimes Against Women of Burma", Available online at: http://zunia.org/post/newreport-on-international-tribunal-on-crimes-against-women-of-burma/ 


\title{
APPENDIX II: Advocacy Letter to Ban Ki-moon, Sent with the New York Tribunal Report
}

\author{
His Excellency Ban Ki-moon \\ Secretary-General \\ United Nations \\ UN Plaza \\ New York, NY \\ 10017 USA
}

June 2010

Dear Secretary-General Ban,

Thank you very much for meeting with us on March 4 in New York. After hearing harrowing stories of brutality inflicted upon the women of Burma by the military junta, we appreciated being able to bring their response directly to your office. It was also a particular honour for the democracy activists of Burma to have a representative, Thin Thin Aung, meet with you as well.

We are writing now to share with you the report of the International Tribunal on Crimes Against Women of Burma, and to urge you to turn our discussion into strong and immediate action for justice in Burma.

The calls for change from within Burma and from the region are growing steadily louder. Many in the international community are getting tired of resolutions that fall on deaf ears. And women are at the forefront of a thriving movement for democracy in Burma itself. Though they have suffered some of the worst crimes at the hands of the military regime, women are also fearlessly working to bring about change.

The enclosed report documents the themes from the testimonies of the 12 Tribunal testifiers - on sexual violence against women, on civil and political violations, and on social, economic and cultural violations of human rights in Burma. Based on the testimonies heard and supporting documentary evidence, the judges concluded that war crimes, crimes against humanity and human rights violations have been and continue to be committed by the Burmese military regime.

Though the egregious human rights abuses in Burma are well documented, the regime continues to act with impunity. The United Nations system must take measures to ensure that the Burmese authorities comply with all international human rights standards and international humanitarian law. A key recommendation from this Tribunal is an ardent call for the UN Security Council to refer Burma to the International Criminal Court. 
Your Special Rapporteur on human rights in Burma, Tomas Quintana, has called for the Security Council to consider the establishment of a Commission of Inquiry into possible crimes against humanity and war crimes in Burma. The UK, Australia, the Czech Republic and the European Parliament, as well as numerous civil society groups, have also voiced public support for the creation of a Commission of Inquiry for Burma. As a powerful advocate for human rights, we urge you to add your voice to the call for a Commission of Inquiry for Burma.

You have also been a fervent supporter of Security Council Resolutions 1325, 1820, 1888 and 1889 , which guarantee women's full participation in post-conflict reconstruction and freedom from all forms of sexual violence. The crimes against the women of Burma must not be ignored. The United Nations must take collective action to ensure the implementation of these resolutions in Burma.

You understand that women's participation is an essential component to the building of sustainable peace and security. The upcoming elections in Burma are based on a constitution which was created and ratified without consultation with civil society, including the women of Burma. This constitution effectively hinders the participation of women in political office, and ignores the ongoing violations of human rights perpetrated against the civilian population by the military regime.

Furthermore, the continued detention of over 2000 political prisoners, including our sister Nobel Laureate Daw Aung San Suu Kyi, undermines the progression of meaningful democracy and peace in Burma. The recent dissolution of the legitimate governing party and official opposition - the National League for Democracy - is evidence of the gravity of the problem. Under these circumstances, the upcoming elections in Burma cannot be considered legitimate by the United Nations or the international community.

The International Tribunal on Crimes Against Women of Burma highlights the crimes and violations committed against women as part of the larger attack on democracy and on the human rights and security of civilian populations in Burma. We sincerely hope that you will use your influence as a global policy-maker to take immediate action on our recommendations.

We thank you for your consideration of this request and look forward to working with you in the future.

Sincerely,

Jody Williams 1997 Nobel Peace Laureate Nobel Women's Initiative
Shirin Ebadi

2003 Nobel Peace Laureate

Nobel Women's Initiative 


\title{
APPENDIX III: Turning Information into Action - What You Can Do for Burma
}

\author{
"Please use your liberty to promote ours." - Aung San Suu Kyi
}

\section{LEARN MORE}

Recent Reports About Women in Burma

- UN Security Council, Report of the Secretary-General pursuant to Security Council resolution 1820, 2008 (20 August 2009)

http://daccess-ddsny.un.org/doc/UNDOC/GEN/N09/405/56/PDF/N0940556.pdf?OpenElement

- In the Shadow of the Junta: CEDAW Shadow Report, Women of Burma (2008) http://www.womenofburma.org/Report/IntheShadow-Junta-CEDAW2008.pdf

- Courage to Resist: Women Human Rights Defenders of Burma, Women's League of Burma (November 2007)

http://www.womenofburma.org/Report/courage-to-resist.pdf

- State of Terror: The ongoing rape, murder, torture and forced labour suffered by women living under the Burmese Military Regime in Karen State, The Karen Women's Organization (February 2007) http://www.karenwomen.org/Reports/state\%20of\%20terror\%20report.pdf

- License to Rape, Shan Women's Action Network (May 2002) http://www.burmacampaign.org.uk/reports/License to rape.pdf

Recent Reports on Burma

- UN Human Rights Council, Progress report of the Special Rapporteur on the situation of human rights in Myanmar, Mr. Tomás Ojea Quintana (10 March 2010) http://daccess-ddsny.un.org/doc/UNDOC/GEN/G10/119/15/PDF/G1011915.pdf?OpenElement

- Crimes in Burma, International Human Rights Law Clinic at Harvard Law School (2009) http://www.law.harvard.edu/programs/hrp/documents/Crimes-in-Burma.pdf

- Impunity Prolonged: Burma and its 2008 Constitution, International Center for Transitional Justice (2009) http://www.ictj.org/static/Asia/Burma/ICTJ_MMR_Impunity2008Constitution_pb2009.p df 
- Women for Peace: Nobel Women's Initiative Delegation to the Thai-Burma border, South Sudan, and the Chadian Border with Darfur, Nobel Women's Initiative (2008) http://www.nobelwomensinitiative.org/about-us/resources/article/nobel-womensinitiative-delegation-reports

\section{TAKE ACTION}

Support the women and people of Burma with one of these organizations:

- Assistance Association for Political Prisoners (Burma) http://www.aappb.org/campaign.html

- Burma Partnership - http://www.burmapartnership.org/tools-for-activists/

- Canadian Friends of Burma - http://www.cfob.org/

- Karen Women's Organization - http://www.karenwomen.org/involved.html

- Nobel Women's Initiative - http://www.nobelwomensinitiative.org/take-action/burma

- Shan Women's Action Network - http://www.shanwomen.org/

- US Campaign for Burma - http://uscampaignforburma.org/take-action

- Women's League of Burma - www.womenofburma.org 